\title{
Between Geography and Transport: A Scientometric Analysis of Port Studies in Journal of Transport Geography
}

\author{
Pre-final version of the article published in Journal of Transport Geography, 81: 102527 (2019) - \\ Special Issue "Celebrating 25 Years of Journal of Transport Geography”
}

\begin{abstract}
César Ducruet
French National Centre for Scientific Research (CNRS), France

Roozbeh Panahi

Department of Supply Chain Management, Asper School of Business, University of Manitoba, Canada Adolf K.Y. Ng

Department of Supply Chain Management, Asper School of Business, University of Manitoba, Canada St. John's College, University of Manitoba, Canada

Changmin Jiang

Department of Supply Chain Management, Asper School of Business, University of Manitoba, Canada Mawuli Afenyo

Department of Supply Chain Management, Asper School of Business, University of Manitoba, Canada
\end{abstract}

\begin{abstract}
Journal of Transport Geography (JTRG)'s scientific production has grown apace in line with the publication trend in general elsewhere, with many researchers of which more or less directly related to geography, who submitting their works to JTRG. Through an investigation of port articles published in JTRG (Group A) and other selected journals categorized into geography journals (Group B), and transport but non-geography journals (Group C) between 2009 and 2018, we strive to answer whether JTRG is more a transport or a geography journal given its double-sided nature. Using a well-defined analytical framework, we analyzed no less than 864 port articles that were categorized in terms of their spatial coverage from global to local, as well as their functional approach in terms of locational, operational, and socio-economic impact nature. Main results reveal that JTRG has a distinct 'from top to bottom' stable pattern with a preference for global level and operational research. Yet, in relative terms, JTRG remains specialized in regional/national spatial scales and in the spatial (locational) perspective. Such a research contributes to a better understanding of the disciplinary evolution of academic research in the field of spatial studies, transport studies, and beyond.
\end{abstract}

\section{Keywords}

Archival corpus; bibliometrics; categorization; geography; port studies; scientometrics; transport studies 


\section{Introduction}

Since its accession to global standards of publishing in 2009, notably the Social Science Citation Index (SSCI), Journal of Transport Geography (JTRG)'s production grew apace with the general trend of publication of similar high standard journals. More researchers, including those with a non-geography background, published their research in JTRG as already observed by Ng and Ducruet ((2014). Given the journal's impact factor steady growth in the past decade up to 2.699 in 2017 (cf. Journal Citation Report website, last accessed in October 2018), JTRG is now generally perceived as a first-tier journal in both geography and transport disciplines.

Given its two-sided nature between geography and transport, we use the case of JTRG to analyse how a given journal evolved during that period, focusing on the respective importance of each main pillar it serves. This raises a crucial question on whether JTRG attracted scholars due to its geographical character and/or to its transport character. How has this subtle equilibrium evolved overtime, do we see a specialization or a stable balance? Previous bibliometric analyses (e.g., Pallis et al., 2010; Woo et al., 2011; Ng, 2013; Ng and Ducruet, 2014; Lau et al., 2017) often looked at a corpus of journals to identify general trends underlying the evolution of port geography as a sub-discipline of human geography ( $\mathrm{Ng}$ and Ducruet, 2014). In fact, very few studies have so far looked at a particular journal's evolution at the crossroads under different influences, of which Notteboom et al. (2013) and Modak et al. (2019). Coincidentally, the $25^{\text {th }}$ anniversary of JTRG make it an ideal moment to critically examine the changing character of geography, transport, with wider implications for the analysis of scientific research in general.

In this study, we analyse a large corpus of papers on port studies published in JTRG and other selected journals over the period January 2009 to June 2018. A bibliometric analysis serves to reveal analytical frameworks underlying those articles. In so doing, we investigate the geography/transport nexus of JTRG papers based on the nature of their cited references. The rest of the paper is structured as follows. Section 2 explains the analytical framework, while Section 3 illustrates the main results. Finally, the discussion and conclusion can be found in Section 4. 


\section{Analytical framework}

To achieve the stated goals, we selected articles in which port was the major focus of the study (hereinafter called 'port articles') from no less than 32 internationally recognized journals published between January 2009 and June 2018. In total, the article sample reaches exactly 864 articles, which we classified as follows: JTRG articles (i.e. Group A, including 1 journal and 98 articles), geography journal articles (i.e. Group B including 21 journals and 69 articles), and transport (but non-geography) journal articles (i.e. Group C including 10 journals and 697 articles) (see Appendix I). All the papers where 'port' (including dry port and inland terminals) is the main theme were included ${ }^{1}$, as in itself port research has fuzzy borders and is hard to delineate.

The first step to create the database is the categorization of articles. There has been substantial research trying to categorize port and shipping articles using different types of categorization while focusing on different issues, e.g., the lack of standard terminology, performance, economy, policy, management, geography, as well as the general research trend, evolution, emergence, and gap analysis (e.g., Bichou and Gray (2005), Heaver (2006), Pallis et al. (2010), Pallis et al. (2011), Woo et al. (2011), Talley (2013), Woo et al. (2012), Ng (2013), Woo et al. (2013), Ng and Ducruet (2014), Ng et al. (2014), Vieira et al. (2014), Lau et al. (2017), Ensslin et al. (in press)). When reviewing them, researchers frequently highlighted the difficulty in establishing a commonly approved framework for categorization, although some similarities could be identified from one study to the other.

In this case, this study mainly uses the one proposed by $\mathrm{Ng}$ (2013) (and later also used by $\mathrm{Ng}$ and Ducruet, 2014) about port geography (Table 1), adding port's future market (1.3.2) as a new focus of research, and completing the list of issues. The framework was developed based on an in-depth literature review of port and transport papers and strengthened by informal discussions with reputable scholars (see $\mathrm{Ng}, 2013$ ). In this paper, we added another dimension to such a

\footnotetext{
${ }^{1}$ In deciding whether 'port' is a particular paper's main theme, we followed the same verification process undertaken by Ng (2013) and Ng and Ducruet (2014). Of course, we recognized that there might be some articles overlooked due to various reasons (e.g., inability to access them, minor interest given to port-related issues). In our opinion, it is important that the list is comprehensive and representative enough for analysis. Indeed, in this study, some core geography journals were not included as they did not offer strong contributions during the interval of investigation, e.g., Economic Geography, Political Geography, etc.
} 
framework: the spatial coverage of port articles: global (foreland and maritime space), regional/national (hinterland), and local (port) scales ${ }^{2}$. This facilitates identifying spatial shifts in researches as will be discussed later in Section 3. For illustrative purposes, all the categories have been marked with respective codes (see Table 1) that will be referred to throughout the paper. In addition, categorization with regards to the aforementioned scales have been further followed up in Table 1 by dividing articles as space-related (locational), activity-related (operation) or consequence-related (impact), and then completed by their specific focus of research to minimize subjectivity. During the study process, we recognized that there were articles that included more than one area of focus. Therefore, the weight of an article that consisted of more than one category is equally divided during the investigation, e.g., 0.5 for each category for an article with two categories.

Starting with foreland and maritime space, the focus of research under its locational perspective is summarized in terms of the "port system" (1.1.1), i.e. mainly investigating a group of ports with a certain level of integration within a given regional setting. This is generally addressed as hierarchy or cluster, in which establishment and development of the system are surveyed, but may also remain at the national scale (e.g. the French seaport system). The operation perspective comprises of two subtypes, namely port connectedness (1.2.1) and port choice; competition and cooperation (1.2.2). Port connectedness articles generally discuss the linkages between ports and their international market (e.g., foreland or overseas markets), while port choice is preferably approached in terms of ports' competency, attractiveness, competition, and cooperation dynamics. The impact perspective also covers two sub-themes: the port's situation in shipping strategies and networks (1.3.1), and its future market(s) (1.3.2). In 1.3.1, a wide variety of issues are discussed, e.g., the intermediacy of ports (see Fleming and Hayuth, 1994), their ability to get inserted into different types of shipping line networks and supply chains. In 1.3.2, a somewhat new area of research is covered based on recent transformations of the shipping industry, such as ship size, fleet overcapacity, changes in freight rates, alterations in international

\footnotetext{
${ }^{2}$ The original framework takes care of two other groups which cannot be easily located based on spatial coverage, namely policy and governance philosophy and epistemology ( $\mathrm{Ng}, 2013)$. Articles in such groups which have issues in common with the three first spatial units (i.e., those with more than one area of focus) are considered in this study. For the rest of them, they are not included.
} 
rules and regulations, the establishment of new maritime routes, and most of all, the formation of vertical and horizontal alliances.

For the hinterland spatial unit, we mainly consider port functions and expansion in terms of the number of stakeholders and the potential mechanisms employed locally and on the land side. Nowadays, ports are considered as the 'middle-man' of trade encountering a wide variety of issues raised by different stakeholders ( $\mathrm{Ng}$ and Liu, 2014). As a consequence, flexible response to such issues is becoming a critical core competency for ports, yet challenging. However, this community of links, nodes and patterns is fully supported by new concepts and technologies, with studies on new logistic corridors, modal substitution, big data, and simulation (Ducruet, 2017). In light of different practical issues involved in this spatial unit, research is on the rise despite the difficulty accessing hinterland flow data (Guerrero, 2014).

\section{[INSERT TABLE 1 ABOUT HERE]}

Research in this area is similarly categorized into three functional perspectives. The first is the locational perspective, where the focus of research is "catchment area and supply chain linkages" (2.1.1). Here, regions which have communication with supply chains through ports are addressed and their evolution is identified. The operation perspective is twofold: port's intermodal transportation and supply chain (2.2.1) and inland/satellite terminal (2.2.2). The first includes discussions about ports' inland connections and related logistical patterns (e.g., logistics sprawl, port regionalization, cargo source, shipper and corridors), the planning and optimization of port and shipping activities (e.g., empty container repositioning, synchromodality and integration). Considering the growing role of inland terminals in such patterns and dynamics (e.g., handling additional port traffic, transloading, servicing regional markets, transshipment), it is separated. Research about the interaction between regional change (e.g., economic development, environmental issues) and port activities are grouped under the "impact" perspective (2.3.1). 
For port space, the focus of research in its locational perspective is again twofold: "history" and "location" (3.1.1). It includes ports' geographical characteristics and their evolution overtime (3.1.2), for instance in terms of port morphology, development stages, analyzed through spatial models and empirical measures. All research mainly addressing port daily challenges and activities are gathered under the "operation" perspective as daily operations (3.2.1). Although it has been conventionally believed that the neighborhood of port and city often generates mutual benefits, the emergence of new concepts in a wide variety of scientific fields (e.g., sustainability, resilience, coupled/synergistic development, port-city ecosystem/interface assessment, optimization of freight distribution patterns, and port-centric logistics) presents new insights and sheds light on overlooked corners. Accordingly, it is believed that the potential role of micro-level studied (e.g., socio-economic role) is either exaggerated or still not correctly perceived. Port expansion, logistic chains, and port externalities ${ }^{3}$ are all among the many drivers introducing the necessity of mutual port-city (waterfront) renewal and/or re-development. There are scholars who are trying to get to the bottom of the interaction mechanisms or introduce system drivers, for the sake of re- bridging the link(s) between port and city. Similarly, research is abundant about planning issues in those two areas considering, for instance port-city mutual direct, indirect, and induced effects. Related research is categorized under port-city relationships (3.3.1).

\section{Empirical results}

To understand the position of JTRG among the three groups of journals, our analysis is divided into three aspects, namely (1) trend of publication, (2) focus of research, and (3) quality and quantity of references.

\subsection{Trend of publication}

Table 2 synthesizes the ten-year list of journals within the groups and among the journals. It illustrates that JTRG is the only geography journal that has published port articles continuously throughout the period under investigation. It has also published the highest quantity of port-related

\footnotetext{
${ }^{3}$ Externalities are indirect effects that can be passed on to third parties, other interests and the wider environment beyond port firms and investors. They could be positive, e.g., innovation and technological progress, or negative, e.g., environmental degradation (Bichou, 2013).
} 
articles. For Group B (geography journals), GeoJournal has the best record of hosting port articles intermittently within seven years with the highest total number of articles in this group.

\section{[INSERT TABLE 2 ABOUT HERE]}

\section{[INSERT FIGURE 1 ABOUT HERE]}

In addition, some interesting correlations between the number of articles featured in JTRG, Transportation Research Part A (TRA) and Transportation Research Part E (TRE) can be identified in Table 1. For instance, throughout the study period, JTRG and TRE share highly similar trends. On the contrary, JTRG and TRA have exactly the opposite trends between 2014 and 2016. During this period, while JTRG suffered a decrease in port articles, while TRA experienced the opposite.

When looking at the number of articles presented in JTRG per year, we find similar patterns for a three-year period starting from a minimum and reaching a maximum, for the first nine years of investigation between 2009 and 2011, 2012 and 2014, and 2015 and 2017. Fig. 1 illustrates the trend of publication with the logarithmic scale on the y-axis of the figure to highlight pattern recognition, as the number of articles published in Group $\mathrm{C}$ is about seven times higher than those in JTRG and Group B. This periodic trend is interrupted as JTRG hosted 12 articles in the first six months of 2018 .

The pattern is different for Group B, where on average about seven articles per year have been published during the study period, while a slightly downward trend could be identified. For Group C journals, there are at least two sub periods - from 2009 to 2011 and from 2015 to 2018. JTRG underwent a similar trend. After passing the first growth period between 2009 and 2011, Group C journals experienced a growing trend (i.e. 65 port articles in the next four years) and between 2015 and 2018, a promisingly stable trend. This result is mainly based on rapid publication growth in two key maritime, non-geography journals: Maritime Policy \& Management and Maritime Economics \& Logistics, but hosting geographic approaches to ports. 


\subsection{Focus of research}

\subsubsection{Spatial unit coverage}

We first counted the number of articles featured in each spatial unit for the three journal groups in terms of normalized number of articles (left), and specialization index of spatial unit (right). Those on the left of Fig. 2 simply show the share of each group in each spatial unit

When looking at the radar diagram of normalized number of articles of JTRG (Group A) in Fig. 2.1, foreland and maritime space has the largest spatial unit discussing global challenges. It has usually been the main scope of articles in this group, among all other spatial units. As the results show, it has the highest number of articles followed by hinterland spatial unit and port spatial unit in the study period, respectively. Here, the share of articles in port unit is highly fluctuating and generally very low when compared with the first two units, while the difference between these two decreased in recent years, starting from 2014.

As noted in the previous sub-section, there is an upward trend in the number of articles published in JTRG from 2015 to 2018, by projecting the result of the first half of 2018 to the second half. This is complemented by harmonized growth of articles in global, regional/national, and local spatial units, in JTRG. Thus, we argue that the growth in articles presented in JTRG per year from 2015 to 2018 is a direct result of a systematic growth of articles in the three aforementioned spatial units. In fact, while there is no harmony within the initial years, a common patterns can be observed' within the last four years. Here, the sudden increase in contribution of local scale articles from 2015 to 2016 could be identified as the main factor for the increase. Overall, this correlation among the growth rates of articles in global, regional/national, and local scales could explain such sustainable growth during this period in which JTRG has offered a balance in attraction. In the meantime, the growth in foreland and hinterland scales is more stable than port scale articles in the last ten years. Although JTRG has grown in terms of port scale articles, still, global and regional/national issues have the two highest shares of research. In fact, we are far from the period of 1950s and 1960s where the focus has been more on single subjects (Ng and Ducruet, 2014). Among the causes of such trends is the growing interest for the worldwide networks of globalizing

players such as shipping lines, terminal operators, but also traders, as well as the integration of new methods borrowed from network analysis and complex networks for instance, allowing to 
study larger port systems with hundreds of nodes and give port geography a decent place in transport network studies long dominated by landward (e.g., road, rail) but with a growing interest for non-physical networks (e.g., multinational firms linkages, communication networks). One example is the study for the first time ever of the global shipping network in relation with urban hierarchies and functions using graph-theoretical networks, going beyond the sole topological dimension of such a world system, in addition over the last 140 years using untapped and harmonized data on both vessel movements and urban population (Ducruet et al., 2018).

As per the normalized number of articles in Group B (Fig. 2.3), regional/national issues have slightly homogeneous contributions over the past decade in geography journals. Two periods of dominance in featured articles are evident during this period, as the global unit has the majority of articles in the first seven years (2011-2016) substituted by local unit articles for the last three years. It does not contradict the previous finding, as local-level studies keep being of paramount importance to renew the study of micro-linkages, such as studies on start-up development (Witte et al., 2018) or firms' linkages across the port-city interface (Van den Berghe et al., 2018; Hesse, 2017; Debrie and Raimbault, 2016) but also studies of terminal concessions and governance (Daamen and Vries, 2013), some of them fully engaged in wider conceptual frameworks in human geography and beyond (see Jacobs and Lagendijk, 2013).

A long-term dominance of local scale articles followed by the simultaneous gradual growth of articles in global and regional/national spatial units is the main characteristic of group C (Fig. 2.5). In other words, it is from 2012 that an increasing trend of articles featuring local unit appeared, followed by global unit and regional/national unit articles, respectively. In the meantime, local scale articles always seem to be the most dominant, followed by global and regional/national scale articles. This is driven by the growing number of articles focusing on local-level activities, often from an operations research perspective on performance, congestion, productivity, and intermodalism.

Overall, JTRG is more "from top to bottom" while Group C is more "from bottom to top" in terms of the frequency of papers published in different spatial units. This seems to be a confirmation of the aforementioned stronger specialization in port operation research of Group C, 
such as at the level of terminals and warehouses for instance (e.g. satellite terminals, logistics sprawl, development of inland platforms) such as Venlo in the Netherlands (Raimbault and Jacobs, 2016) but also wider approaches from a conceptual and theoretical point of view (Monios and Wilmsmeier, 2013). There is another point when comparing JTRG and Group C diagrams (Fig. 2.1 and Fig. 2.3). They have both experienced a decrease in articles of their main unit in 2018 considering that the period only includes the first half of 2018 (global unit for JTRG and local unit for Group C), while this is not the case for their second- and third-ranked articles. This pattern is different for Group B in which local and global levels have been almost similarly addressed, thanks to periodic dominance of articles featured in these units over the years (i.e., global unit from 2011 to 2016 and local unit from 2017 to 2018), followed by articles in regional/national level. In other words, smooth patterns cannot be identified here, unlike JTRG and Group C.

Diagrams represented on the right-hand side of Fig. 2 provide a comparative analysis among JTRG, Groups B and C. While the focus of JTRG on regional/national spatial unit is higher than for the two other groups (almost two times higher than Group C), JTRG is specialized on global level studies compared with Group C on local studies. This confirms earlier observations.

Random specialization and balanced specialization are the main characteristics of Groups B (Fig. 2.4) and C (Fig 2.6), respectively. They are different from earlier results based on the normalized number of articles in these two groups, especially for Group C. Although the share of articles in "local spatial unit" is much higher than the two other spatial units in Group C, the number of articles featured in different spatial units are much higher in Group $\mathrm{C}$ than two other groups; resulting in specialization index of spatial units all close to one for Group C. This is perhaps because Group C is not only specialized in local, micro-level studies but is much more diverse than the two other groups as it addressed issues at all scales.

\section{[INSERT FIGURE 2 ABOUT HERE]}

\subsubsection{Functional perspective coverage}

Analogous to our previous analysis of journals' trends with respect to spatial unit coverage, it is important to highlight distinctions and similarities in terms of functional perspective (i.e., 
location, operation, and impact) which was defined for global, regional/national and local spatial units. Therefore, functional perspectives are treated as similar to spatial units (Fig. 3).

It can be concluded from the left hand side of Fig. 3 that operation-related articles have the highest share when compared with articles featured in locational and impact perspectives in both JTRG (Fig. 3.1) and Group C (Fig. 3.5), while this is not the same for Group B (Fig. 3.3). In Group $\mathrm{B}$ impact-related articles are more dominant. This could be explained by the higher importance of the urban and regional socio-economic (and therefore spatial) dimension to Group B articles, dealing more with waterfronts, industrial clusters, start-ups, and multivariate analyses of the portregion linkage (Ducruet and Itoh, 2016). In the meantime, the difference in the share of articles (with respect to their functional perspective) is higher in Group $\mathrm{C}$ when compared to the more homogenous pattern in JTRG. There is a greater balance between locational and impact-related articles in JTRG than Group C where operation-related articles are popular. In this regard, Group $\mathrm{B}$ is similar to Group $\mathrm{C}$ as the difference between impact-related articles and the two other functional perspectives is high. Here, both location-related and operation-related articles have similar contributions. Such a pattern may result in absolute dominance of their top functional perspective in the near future for these two groups.

By looking at the right-hand side of Fig. 3, we can discuss specialization based on a more comparable scale. For JTRG, its specialization in both locational and functional perspective is evident (Fig. 3.2). Here, its impact and operation specialization indices are very close to each other. Similarly for Group B, the locational perspective is dominant (Fig. 3.4), while its impact perspective has the highest share compared with other groups (Fig. 3.3). Thus, both JTRG and Group B are dominated by the locational perspective (cf. specialization index), while Group C is more specialized in operation-related studies. This confirms the more operational nature of Group $\mathrm{C}$ and the more locational nature of Group B and also JTRG under this perspective; in other words, "space" matters more for geography-oriented journals than for pure transport journals.

[INSERT FIGURE 3 ABOUT HERE] 
By implementing both normalized number of articles and specialization index we can investigate journals both locally (i.e., within-group analysis), and globally (i.e., between-group analysis). In this regard, we can combine findings of sections 3.2.1 and 3.2.2, as follows:

○ Within-group analysis shows that JTRG has a distinct 'from top to bottom' stable pattern (i.e., global level articles on the top followed by regional/national and local ones generally in all years under investigation), with a dominance of operation-related articles, followed by a balance between locational and impact / functional perspectives. Group B is less specialized, although it is somewhat dominated by the impact / functional perspective. Group $\mathrm{C}$ is dominated by the local spatial unit, mainly due to its overwhelming operation functional perspective. Considering the inclination of functional perspective patterns identified in Groups B and C, they are in fact dominated by impact and operational perspectives, and this is likely to continue in the near future.

○ Between-group analysis shows that JTRG is more specialized in regional/national spatial unit with greater emphasis on the locational perspective. Group B has no specific spatial unit specialization but an emphasis on the locational perspective. Group C exhibits a more balanced specialization in terms of spatial unit, with, again, more emphasis on operational perspectives. This again confirms that JTRG and geographic journals (Group B) give more importance to location and space then Group $\mathrm{C}$ which is more focused on operational research.

\subsubsection{Intersection of spatial units and functional perspectives}

Here it is important to investigate whether the stated recognized trends also apply to the different spatial units (global, regional/national, and local), say, if there is a similarity in share of locational-related, operation-related, impact-related articles in JTRG when investigating the case in each spatial scale. Further work needs to be done to investigate if all spatial units have been treated similar to each other, or whether the trend is different from one spatial unit to another in the three groups of journals. Marei and Ducruet (2015), however, calculated that based on the work of $\mathrm{Ng}$ and Ducruet (2014) covering 399 papers about ports in geography journals between 1950 and 2012 , that a majority $48 \%$ of this corpus focussed on a single port, $22 \%$ on the country level, $10.3 \%$ on subnational studies, $13.5 \%$ on transnational studies, less than $1 \%$ encompassing entire maritime basins or regions, and only $5.5 \%$ on the world scale. 
Thus, after this assessment of journals in terms of spatial unit and functional perspective, it appears necessary to combine them together. This will help us to identify the share of each functional perspective under different spatial units. Starting from foreland and maritime space articles, the results are illustrated in Fig. 4.

As per Fig. 4, there are some distinct patterns over the last ten years in JTRG, starting with impact-related articles being the majority for the first three years (2009-2011), which includes two research focuses (1.3.1 and 1.3.2 in Table 1). Among the presented topics in Table 1, the impact of technological improvements on ports is less considered in JTRG, while the dynamics between shipping networks and port networks, inter-industry partnerships and integrations, spatial polarizations, port scope expansion and opportunities in bunkering markets were among the main impact-related topics. A similar pattern is observed in Group B, with a one-year delay (2010-2012). The spatial approach is again dominant in those two groups compared with Group C.

Locational-related articles dominate the following four years (2012-2015) which is also obvious in Group B with a longer delay than the first case (2015-2017), so the aforementioned trend is prolonged. During this period, emergence, shift, and evolution of international port ranges, as well as identification and monitoring of hierarchies were covered as locational-related topics. It is important to mention that transnational studies at the level of entire maritime ranges or basins started to become relatively common in geography, planning, and regional science (Arvis et al., 2019).

This periodic dominance of individual perspectives (i.e., impact-related perspective from 2009 to 2011 and locational-related perspective from 2012 to 2015) was no longer the case over the last three years, as there is more balance among all the functional perspectives in JTRG. For Group $\mathrm{C}$, the trend is completely different from the swinging dominance of perspectives as understood for JTRG and Group B. The shares of impact-related articles grew continuously over the last ten years with dominance of impact-related articles discussing foreland and maritime space. The specialization of Group $\mathrm{C}$ on the more local scale is emblematic of its main focus on intra-port issues (operations) such as the level of terminals looking, among other topics, at ship 
turnaround time, productivity, intermodalism, infrastructures, and management. Therefore, within port research, we can conclude that JTRG has been the leader in taking care of impact-related articles and at the global scale, such a trend being somewhat followed in subsequent years by both Group B and Group C. The periodic dominance of functional perspectives in JTRG can be interpreted as a synergetic dynamic among scholars who have published articles on the global scale over the past decade.

\section{[INSERT FIGURE 4 ABOUT HERE]}

Also, JTRG is among the very first journals to address the future market opportunities for ports within the period of investigation with support of trend analysis, simulation, interviews, and scenarios including complex factors, such as the effect of the inter-play among stakeholders at present and in the future. On the other hand, operation-related articles in the global space have always had the lowest rank in JTRG compared to the other two perspectives, which have the majority of articles in total (e.g., in 2009, 2011, 2014, 2016, 2017) (Fig. 3). Hence, operationrelated articles are apparently the main focus of JTRG either at the regional/national unit or at the local unit, or both, but not at the global one, which is more related to an increasing number of studies on global networks with both locational and impact perspectives (e.g. Frémont, 2007), but using more advanced tools such as complex networks (e.g. Gonzalez Laxe et al, 2012), like in Group $\mathrm{C}$ that underwent a growing interdisciplinary composition of the authors, from physics to computer science, economics, and operations research (e.g., Kaluza et al., 2010 for an example outside our study sample). The more local scale of Group C is still confirmed nowadays with works on micro-communities for instance (Viljoen and Joubert, 2019).

When analyzing the share of functional perspectives in the hinterland spatial unit as illustrated in Fig. 5, it is obvious that operational issues have the highest attraction in all groups. Although operation and non-operation perspectives are different in nature, it is the biggest focus for the JTRG group. Articles featured in regional/national space have been more prone to focus on operational aspects rather than locational and impact challenges, over the last ten years. Here it is evident that the place between impact-related and locational-related articles has changed over the years, in which recent years belong to locational-related articles (2015-2018) while it has been 
occupied by impact-related articles in the first six years (2009-2014). This is completely different for Group B that was dominated by operation-related articles at the beginning, and later substituted by impact-related articles. So, we can conclude that impact-related articles firstly featured in JTRG when compared to all other geography journals. Thus, JTRG maintains a keen interest for spatial aspects but at the same time, developed an operational dimension like in transport journals. When analyzing Group C's radar diagram in Fig. 5, a balance between impact and operation perspectives was formed in recent years with a decreasing share of operation perspective from 2009 to 2014. Here, the share of locational-related articles is very low in Group C, especially when compared to the emergence of such articles in JTRG in recent years. Finally, the balance between 2.2.1 and 2.2.2 is similar in JTRG and Group C as one-fourth of operation-related articles discuss inland/satellite terminals over the ten years (e.g. Ng et al., 2013), while this ratio is about one-third in Group B.

Here it is interesting to compare this pattern of JTRG in regional/national space (Fig. 5) with that of the global space (Fig. 4). The radar distribution of JTRG in both spatial units have something in common, as they both have periods of dominance. While operation-related articles are always the minority in the global unit and the majority in the regional/national unit, there are still two periods in both of them which first focus impact-related articles and then locationalrelated articles with a similar sequence, although the share is not comparable.

\section{[INSERT FIGURE 5 ABOUT HERE]}

At the same time, during this period, the role of ports in the development of multimodal transport and logistics has been less considered among operation issues. For the other issues, they have been investigated in terms of supply chain integration, inland transport capacity, constraints and trip generation, modal substitution and freight allocation, and more frequently, spatial patterns identification and optimization. Although one could find some sort of similarity when investigating journals in the hinterland spatial unit, it is difficult to find them in the local spatial unit. Articles on port-city relations (3.3.1 in Table 1) and the impact-related research focus concentrate the majority among geography journals (both JTRG and Group B), although the share of such articles is higher in Group B than in JTRG (see Fig. 6). Other functional perspectives have been frequently 
discussed over the past decade but they have rarely reached a majority of articles in these two groups. In fact, it should be remembered that articles related to the local unit have the lowest share in JTRG, when compared to other spatial units. This is completely different for Group C in which daily operations (3.2.1) as the operation-related focus of research is the most important one, covering a wide variety of issues and more generally, local space articles have the highest share of all articles published in Group C. Indeed, the most important issues addressed in JTRG are about identification of complexities at the interface of port and city, and integration of port and city planning to minimize conflicts and maximize port-city relation bilateral benefits (e.g., FDI attraction and start-up establishments), while Group C is more about, as mentioned above, terminal performance and port efficiency.

\section{[INSERT FIGURE 6 ABOUT HERE]}

\subsubsection{Interrelation among articles}

There are always papers addressing more than one issue. So, using frameworks may not result in a complete picture. As mentioned earlier, to address this issue, we weighted articles , resulting in co-occurrence linkages. Our investigation showed that about $10 \%$ of articles in our database belong to more than one category. This is represented in Fig. 7 with support of Gephi software (Bastian et al., 2009) Here, operation-related articles in the foreland and maritime space have the highest frequency (i.e., 1.2 in Table 1), connecting to 36 articles in 7 categories. This is approximately the same for operation-related articles in the hinterland spatial unit (i.e., 2.2 in Table $1)$ in terms of the number of connections, but this category has a higher degree, connecting to all 8 remaining categories, with a more balanced pattern. Looking at articles in different spatial units in terms of the number of connections, there are global spatial unit articles on the top, followed by regional/national and port unit articles. This means that global-level studies have become prominent, following the study of global shift, global production networks, and global commodity and value chains in the mainstream literature (Jacobs et al., 2010).

\section{[INSERT FIGURE 7 ABOUT HERE]}

\subsubsection{General coverage}


By counting the number of rows in the third column of Table 1 (focus of research), articles featured in the three groups are categorized into 13 distinct disciplines. So, it is possible to compare JTRG, Groups B and Group C in terms of the number of disciplines covered per year, during the past decade (Fig. 8). JTRG is between Group B and Group C, with three lowest scores in 2009, 2012, and 2015. So, we can conclude that articles are growing for JTRG in line with the number of covered disciplines that can result in presenting a wide variety of challenges mostly related to renewed approaches through interdisciplinary collaboration and a growing importance og the global scale This is an interesting uniqueness of JTRG considering its total number of articles compared with those of Group B (including 23 journals), and Group C (including 10 journals).

\section{[INSERT FIGURE 8 ABOUT HERE]}

\subsection{Referencing analysis}

\subsubsection{Number of references}

Investigating the number of references in a specific discipline is an interesting subject with lots of applications. To this end, regarding the number of reference citations in journals, generally, there is no specific number or range that is considered as normal or standard by scientific experts. However, there can be a measure to determine the level of originality as long as the similarity of disciplines under investigation is identified and comparable across journals and across groups. Likewise, it can be used to assess the complexity of articles, e.g., for those which combine more than one subject.

To shed light on this issue in the field of port articles, nominated papers extracted in JTRG and Group B were investigated in terms of the average number of references per article. As illustrated in Fig 9, the number of references investigated in JTRG articles is normally in the range of 40 to 60 references while this is from 60 to 80 for Group B (more theoretical), although they are occasionally close to each other (e.g., in 2015 and 2016). Although this number could be interpreted as a level of originality, it could also be that Group B consists of "core geography"

journals and so reviewers and editors are more demanding in terms of including "core geography theories and concepts". While in JTRG, authors may only need to review "transport geography/transport papers", yet to get published in Group B journals, authors need to review both 
"transport geography/transport papers" and "geography (not directly related to transport) papers". All in all, this is only a recent trend and it is perhaps too early to draw definitive conclusions.

\section{[INSERT FIGURE 9 ABOUT HERE]}

\subsubsection{Distribution of references}

Another approach to analyze referencing is the count of how many times JTRG articles cite each article group (A, B, and C) over time. The distribution and proportion is a good proxy to studying the nature of the influence on JTRG articles. As mentioned earlier and as studied by $\mathrm{Ng}$ and Ducruet (2014) across a large sample, port geography up to 2012 exhibited a fading influence from "core geography" due to its stronger attraction towards transport journals and thus more focused on operational issues or other specialized research. Zooming on JTRG only, and extending the covered period back to 1994 (Fig. 10) allows us to discuss a wider trend and verify the applicability of this indicator to JTRG.

Our findings show that 2009 had been a turning point in JTRG's production as reflected in the sudden absolute growth of references for the three groups including Group A. The relative distribution of references or citations exhibits several interesting trends. First, except from the exceptional values of 1999 and 2002, the share of JTRG's self-citations has grown apace across the period, with a faster increase since the late 2000s up to the present. This evolution is all but a confinement since the three shares lean towards a balance in early years. Secondly, the number and share of Group B references also increased steadily, meaning that "core geography" had regained its loss to Group C. JTRG articles revived their interest for human geography (including economic and urban geography, but also spatial planning and regional science) or "space" in general after a period of decline. In fact, specialized transport research (i.e., operations research,

management), which dominantly influenced JTRG articles in the mid-2000s, had become integrated - rather than separated from - geographical and spatial issues as geographers and other scholars felt the need to reassemble fundamental and applied research through this specific journal that offers both approaches. 
Yet, this trend is only partially true since individual JTRG articles often remain influenced by one specific group, B or C (Fig. 10). In fact, only 6 Group A articles cite JTRG for over 50\% of their reference list, while all the JTRG articles citing Group C for more than $50 \%$ of their reference list barely cite Group B, i.e. $4.3 \%$ on average (of which 20 articles with no reference to Group B), against $20.3 \%$ for Group A (JTRG). Therefore, the analysis of JTRG citations offers mixed evidence, as geography kept and increased its influence alongside transport studies, but the two latter groups remain less dominant. Overall, such an analysis still means that JTRG's production had managed to overcome too much transport specialization by welcoming mainstream influences from human geography, among others. However, transport specialization remains essential but not any more dominant so that the spatial character of the journal remains strong.

\section{[INSERT FIGURE 10 ABOUT HERE]}

In the middle of the figure, several articles keep a relative balance between Group $\mathrm{C}$ and Group B, while their references to JTRG articles remain lower than the latter two, respectively. Their choice to publish in JTRG can thus be explained by their will to integrate separate worlds, often through a strong methodological focus such as network analysis for instance. This latter trend is crucial as it shows to what extent Journal of Transport Geography had become a "laboratory" of transdisciplinary approaches in relation to transport but also emerging methodologies and research foci, beyond transport itself. In the same vein, Group B specialization often translates a new approach to classical concepts about urban and regional geography, such as cities, hinterlands, and corridors, revisiting the port-city interface and port-region linkages through novel methodologies and increased ties with mainstream urban geography and urban studies. Group $\mathrm{C}$ specialization makes strong use of modeling from various angles such as econometrics, Geographical Information Systems, Agent-Based Models, and simulation, for mainly quantitative analyses of transport chain actors and their performances. Many Group C articles do not mention geography journals at all, while only 3 articles belonging to Group B do not use Group C articles as their reference.

[INSERT FIGURE 11 ABOUT HERE] 
The aforementioned transport specialization amongst JTRG articles thus stands apart, with a much more imbalanced distribution of citations than other groups. On the one hand, this specialization is necessary as it keeps strong ties with what is going on in (mainstream and applied) transport studies, but does not influence geography. On the other, the same trend can be explained by the fact that transport geographers keep geography as their core interest while Group C specialization is the outcome of non-geographers mostly, having a "affinity for space" when

publishing in JTRG but not being aware of or concerned by mainstream geographic issues. This is because their goal is mainly to push further transport studies on its operation side. In terms of publication strategies, JTRG might have become a fruitful outlet for transport specialists to publish their work in a highly ranked journal without suffering from the burdens imposed by "pure" transportation journals.

Further research shall undertake a comparable citation analysis of Group B and Group C to verify whether such articles are to some extent connected. In any case, our analysis demonstrates that JTRG offers a common ground to a variety of scholars from all horizons, whether they are geographers or not, thereby fostering even more transversal and transdisciplinary dialogues among them.

\section{Discussion and conclusion}

Journal of Transport Geography (JTRG)'s scientific production has grown apace in line with the general trend of publications emerging in the past decade, with many researchers, including those with backgrounds not directly related to geography, submitting their works to JTRG. Through the categorization of 864 port articles published in JTRG (98 articles), core geography journals (Group B including 21 journals and 69 articles), and (non-geography) transport journals (Group C including 10 journals and 697 articles), between 2009 and June 2018, we attempted to answer whether JTRG created uniqueness as a transport/geography journal while such a study may improve our understanding of the general mechanisms of publications in academia.

We believe that our analysis could be a useful contribution to the current literature where there is a tension between specialization and transversality (or transdisciplinary studies). We thus used JTRG as an interesting case study actively torn between "transport" and "geography" to 
examine to what extent these two worlds have been or not interlinked overtime, and especially after the journal became SSCI, i.e., in some way more attractive to a wider audience and authors than in the past. We test the degree and nature of this interplay throughout the paper, which is our main contribution.

Our investigation based on the normalized number of articles, and the specialization index applied to within-group and between-group analysis, respectively, demonstrated that JTRG experienced a distinct pattern over the past decade compared with other journals. There were always foreland and maritime space articles on the top followed by those addressing hinterland and port spatial units. In terms of functional perspective of such articles, we can see the dominance of the operational perspective. For Group B, it is a random pattern, while for Group C, the absolute dominance of port spatial unit articles is obvious. When compared with Group B and C, we can highlight JTRG for its specialization about hinterland articles with more emphasis on the locational perspective. Again, Group B offers a random pattern in spatial units, with also a dominance on the locational perspective. Such a distribution could reflect equal contribution of geography into all spatial units at least for the last ten years. In the meantime, similarity in dominance of functional perspective between JTRG and Group B could be a sign of completion/complementing between them. For Group C, it is a well-balanced specialization in terms of articles featured in different spatial units, while they have been more prone to address operational perspectives.

As there are always papers contributing to more than one category, it provided a great chance to see how they are interrelated. In other words, it was important to verify whether any strong alliance among different spatial units exists, as for functional perspectives. Our investigation shows that from top to bottom, foreland and maritime space articles have the highest contribution into multidisciplinary studies, followed by those addressing hinterland, and port spatial units. Additionally, among different functional perspectives, we can mark operation-related articles as those with the highest contribution in multidisciplinary studies. Considering withingroup analysis, we can argue that papers featured in JTRG had more contribution into multidisciplinary studies compared to those featured in the two other groups. 
Analyzing the number of publications shows that there are some correlations among JTRG and transport journals (e.g., TRA and TRE). This raises the question: is JTRG competing/complementing such mainstream transport journals? This is of great importance when looking at fluctuations in the number of port-related articles featured in JTRG over the past ten years. To answer this question comprehensively, perhaps further research also needs to investigate submitted papers rather than just accepted/published ones.

By investigating the number of covered disciplines, we can conclude that JTRG is between Groups B and Group C, with bottom limit and upper limit over the past decade, respectively. This number has experienced fluctuations over previous years. In-line with stability in the number of areas covered by JTRG articles in recent years, a stable trend of port articles published per year is evident. Therefore, it is important for managers of JTRG (e.g., its editorial board) to attract more interdisciplinary research.

Further, referencing analysis of JTRG shows a balance between the share of transport and geography references. However, transport specialization remains essential but not anymore dominant so that the spatial character of the journal remains strong. Nevertheless, there are still questions to answer, for instance, whether short and long-term data analysis at various spatial scales and functional perspectives can be further addressed. As a complementary analysis, further studies can be proposed to investigate co-authorships for instance. Another research pathway is the analysis of keywords overtime. Following the idea of investigating interrelations among different categories, we can monitor the evolution of such articles overtime. The analysis of references could be pushed further to introduce measures of originality/complexity and look at the other side of the coin, i.e., how other journals are influenced by JTRG over time.

\section{References}

Arvis, J.F., Vesin, V., Carruthers, R., Ducruet, C., de Langen, P.W. (2019) Maritime Networks, Port Efficiency, and Hinterland Connectivity in the Mediterranean. Washington DC: World Bank Group, International Development in Focus. 
Bastian, M., Heymann, S., Jacomy, M. (2009) Gephi: An open source software for exploring and manipulating networks. Paper presented at the International AAAI Conference on Weblogs and Social Media, May 17-20, San Jose CA.

Bichou, K., Gray, R., 2005. A critical review of conventional terminology for classifying seaports. Transportation Research Part A: Policy and Practice 39 (1): 75-92.

Bichou, K., 2013. Port operations, planning and logistics. Informa Law from Routledge, NY: USA.

Daamen, T.A., Vries, I. (2013) Governing the European port-city interface: institutional impacts on spatial projects between city and port. Journal of Transport Geography 27: 4-13.

Debrie, J., Raimbault, N. (2016) The port-city relationships in two European inland ports: A geographical perspective on urban governance. Cities 50: 180-187.

Ducruet, C. (2017) Advances in Shipping Data Analysis and Modeling. Tracking and Mapping Maritime Flows in the Age of Big Data. London \& New York: Routledge.

Ducruet, C., Cuyala, S., El Hosni, A. (2018) Maritime networks as systems of cities: The longterm interdependencies between global shipping flows and urban development (18902010). Journal of Transport Geography, 66: 340-355.

Ducruet, C., Itoh, H. (2016) Regions and material flows: Investigating the regional branching and industry relatedness of port traffic in a global perspective. Journal of Economic Geography, 16(4): 805-830.

Ensslin, L., Dezem, V., Dutra, A., Ensslin, S. R., Somensi, K., in press. Seaport-performance tools: an analysis of the international literature. Maritime Economics \& Logistics. 10.1057/s41278-017-0083-7.

Fleming, D.K., Hayuth, Y. (1994) Spatial characteristics of transportation hubs: Centrality and Intermediacy. Journal of Transport Geography, 2(1): 3-18.

Frémont, A. (2007) Global maritime networks: The case of Maersk. Journal of Transport Geography 15(6): 431-442.

Gonzalez Laxe, F., Freire Seoane, M.J., Montes, C.P. (2012) Maritime degree, centrality and vulnerability: Port hierarchies and emerging areas in containerized transport (2008-2010). Journal of Transport Geography, 24: 33-44.

Guerrero, D. (2014) Deep-sea hinterlands: Some empirical evidence of the spatial impact of containerization. Journal of Transport Geography, 35: 84-94. 
Heaver, T.D., 2006. The evolution and challenges of port economics. In: Port Economics, ed. K. Cullinane and W. K. Talley, 11-41. Oxford, UK: Elsevier.

Hesse, M. (2017) Approaching the relational nature of the port - city interface in Europe: Ties and tensions between seaports and the urban. Tijdschrift voor Economische en Sociale Geografie 109(2): 210-223.

Journal Citation Report (2018)

website:http://jcr.incites.thomsonreuters.com/JCRJournalHomeAction.action?pg=JRNLH OME\&categoryName=GEOGRAPHY\&categories=KU\#, last accessed in October 2018.

Jacobs, W., Ducruet, C., de Langen, P.W . (2010) Integrating world cities into production networks: The case of port cities. Global Networks 10(1): 92-113.

Jacobs, W., Lagendijk, A. (2013) Strategic coupling as capacity: how seaports connect to global flows of containerized transport. Global Networks 14(1): 44-62.

Kaluza, P., Kölzsch, A., Gastner, M.T., Blasius, B. (2010) The complex network of global cargo ship movements. Journal of the Royal Society Interface 7(48): 1093-1103.

Lau, Y.Y., Ducruet, C., Ng, A.K.Y., Fu, X., 2017. Across the waves: a bibliometric analysis of container shipping research since the 1960s. Maritime Policy \& Management 44(6): 667684.

Mareï, N., Ducruet, C. (2015) The regionalization of maritime networks: Evidence from a comparative analysis of maritime basins. In: Ducruet C. (Ed.), Maritime Networks: Spatial Structures and Time Dynamics, London and New York: Routledge, pp. 330-350.

Modak, N. M., Merigó, J. M., Weber, R., Manzor, F., Juan de Dios Ortúzar, J., 2019. Fifty years of Transportation Research journals: A bibliometric. Transportation Research Part A 120(2019): 188-223.

Monios, J., Wilmsmeier, G. (2013) The role of intermodal transport in port regionalization. Transport Policy 30: 161-172.

Ng, A.K.Y., 2013. The evolution and research trends of port geography. The Professional Geographer 65(1): 65-86.

Ng, A.K.Y., Ducruet, F., 2014. The changing tides of port geography (1950-2012). Progress in Human Geography 38(6): 785-823. 
Ng, A.K.Y., Ducruet, C., Jacobs, W., Monios, J., Notteboom, T., Rodrigue, J.-P., Slack, B., Tam, K.-C., Wilmsmeier, G., 2014, Port geography at the crossroads with human geography: between flows and spaces. Journal of Transport Geography 41: 84-96.

Ng, A.K.Y., Liu, J.J., 2014. Port-Focal Logistics and Global Supply Chains. Palgrave Macmillan, Basingstoke.

Ng A.K.Y., Padilha F., Pallis A.A. (2013) Institutions, bureaucratic and logistical roles of dry ports: The Brazilian experiences. Journal of Transport Geography, 27: 46-55.

Notteboom, T., Pallis, A.A., De Langen, P.W., Papachristou, A., 2013. Advances in port studies: the contribution of 40 years Maritime Policy \& Management. Maritime Policy \& Management 40(7): 636-653.

Pallis, A. A., Vitsounis, T. K., De Langen, P. W., 2010. Research in port economics, policy and management: A review. Transport Reviews 30(1): 115-61.

Pallis, A. A., Vitsounis, T. K., De Langen, P. W., Notteboom, T. E., 2011. Port economics, policy and management: Content classification and survey. Transport Reviews 31(4): 445-471.

Raimbault, N., Jacobs, W., van Dongen F. (2016) Port Regionalisation from a Relational Perspective: The Rise of Venlo as Dutch International Logistics Hub. Tijdschrift voor Economische en Sociale Geografie 107(1): 16-32.

Talley, W. K., 2013. Maritime transportation research: topics and methodologies. Maritime Policy \& Management 40(7): 709-725.

Van den Berghe, K., Jacobs, W., Boelens, L. (2018) The relational geometry of the port-city interface: Case studies of Amsterdam, the Netherlands, and Ghent, Belgium. Journal of Transport Geography 70: 55-63.

Vieira, G. B. B., Neto, F. J. K., Amaral, F. G., 2014. Governance, governance models and port performance: A systematic review. Transport Reviews 34(5): 645-662.

Viljoen N.M., Joubert J.W. (2019) Supply chain micro-communities in urban areas, Journal of Transport Geography, 74: 211-222.

Witte P., Slack B., Keesman M., Jugie J.H., Wiegmans B. (2018) Facilitating start-ups in port-city innovation ecosystems: A case study of Montreal and Rotterdam. Journal of Transport Geography 71: 224-234. 
Woo, S. H., Pettit, S. J., Kwak, D. W., Beresford, A. K. C., 2011. Seaport research: A structured literature review on methodological issues since the 1980s. Transportation Research Part A: Policy \& Practice 45 (7):667-85.

Woo, S. H., Pettit, S. J., Beresford, A. K. C., Kwak, D. W., 2012. Seaport research: A decadal analysis of trends and themes since the 1980s. Transport Reviews 32(3): 351-377.

Woo, S. H., Kang, D. J., Martin, S., 2013. Seaport research: An analysis of research collaboration using social network analysis. Transport Reviews 33(4): 460-475. 


\section{Table 1 Categorization framework of port articles featured in journals ( $\mathrm{Ng}$ (2013) with slight modifications)}

\begin{tabular}{|c|c|c|c|}
\hline Spatial Unit & $\begin{array}{l}\text { Functional perspective } \\
\text { within the maritime } \\
\text { industries }\end{array}$ & Focus of research & Issues \\
\hline \multirow{5}{*}{$\begin{array}{l}\text { Foreland and } \\
\text { maritime space } \\
\text { (global) (1) }\end{array}$} & Locational (1.1) & Port system (1.1.1) & $\begin{array}{l}\text { Port hierarchy; development of international/ national } \\
\text { port. }\end{array}$ \\
\hline & Operation (1.2) & Connectedness (1.2.1) & Connections of ports with foreign markets. \\
\hline & & $\begin{array}{l}\text { Competition and cooperation } \\
(1.2 .2)\end{array}$ & Port choice; port attractiveness; inter-port relation. \\
\hline & Impacts (1.3) & $\begin{array}{l}\text { Port's place in shipping strategies } \\
\text { and networks (1.3.1) }\end{array}$ & $\begin{array}{l}\text { Concentration and deconcentration; hub development; } \\
\text { impacts of technological improvements on ports; } \\
\text { relation between ships and ports; impacts of } \\
\text { shipping line and shipowners strategies on ports. }\end{array}$ \\
\hline & & Port's future market (1.3.2) & Future opportunities; port adaptation. \\
\hline \multirow{4}{*}{$\begin{array}{l}\text { Hinterland } \\
\text { (regional/ } \\
\text { national) (2) }\end{array}$} & Locational (2.1) & $\begin{array}{l}\text { Catchment areas and supply chain } \\
\text { linkage (2.1.1) }\end{array}$ & Shrinking hinterland; evolution over time. \\
\hline & Operation (2.2) & $\begin{array}{l}\text { Port, intermodal transportation, } \\
\text { and supply chain }(2.2 .1)\end{array}$ & $\begin{array}{l}\text { The role of ports in the development of multimodal } \\
\text { transportation and logistics; Port's inland } \\
\text { connection; relation between ports and cargo } \\
\text { sources/ shippers. }\end{array}$ \\
\hline & & Inland/satellite terminal (2.2.2) & $\begin{array}{l}\text { Functions and operations of inland terminals, and their } \\
\text { relations with ports. }\end{array}$ \\
\hline & Impacts (2.3) & $\begin{array}{l}\text { Port and regional development } \\
(2.3 .1)\end{array}$ & $\begin{array}{l}\text { Feasibility studies, impact assessments of port projects } \\
\text { and intermodal facilities on regional and nonurban } \\
\text { surroundings, including port development, climate } \\
\text { change and environment issues, port and } \\
\text { international trade; impacts of economic } \\
\text { development on ports. }\end{array}$ \\
\hline \multirow[t]{4}{*}{$\begin{array}{l}\text { The port (local) } \\
\text { (3) }\end{array}$} & Locational (3.1) & History and location (3.1.1) & $\begin{array}{l}\text { Geographical characteristics, cost-benefit analysis in } \\
\text { port site selection; History of port international } \\
\text { trade. }\end{array}$ \\
\hline & & Evolution over time (3.1.2) & $\begin{array}{l}\text { Composition of the port community; stages of port } \\
\text { development; port morphology. }\end{array}$ \\
\hline & Operation (3.2) & Daily operations (3.2.1) & $\begin{array}{l}\text { Resource allocation; port planning and marketing; port } \\
\text { performance, efficiency, service quality; port } \\
\text { pricing; safety, security, sustainability and } \\
\text { environmental issues; information for port } \\
\text { planning and operation; maintenance. }\end{array}$ \\
\hline & Impact (3.3) & Port-city relation (3.3.1) & $\begin{array}{l}\text { Water front redevelopment and port-city relational } \\
\text { geography, business and economy; spatial projects } \\
\text { and land use conflicts; port and transport labor } \\
\text { issues; sustainability and environmental issues. }\end{array}$ \\
\hline
\end{tabular}


Table 2 List of journals in three different groups featured port articles together with distribution of articles during the period between 2009 and June 2018

\begin{tabular}{|c|c|c|c|c|c|c|c|c|c|c|c|}
\hline Journal & 2009 & 2010 & 2011 & 2012 & 2013 & 2014 & 2015 & 2016 & 2017 & 2018 & Total \\
\hline \multicolumn{12}{|l|}{ Group A (JTRG) } \\
\hline Journal of Transport Geography & 4 & 12 & 13 & 4 & 10 & 11 & 4 & 10 & 18 & 12 & 98 \\
\hline \multicolumn{12}{|l|}{ Group B (geography journals) } \\
\hline The Annals of Regional Science & & 1 & & & 2 & & & & & & 3 \\
\hline $\begin{array}{l}\text { Annals of the Association of American } \\
\text { Geographers }\end{array}$ & & 1 & 1 & & & & 1 & & & & 3 \\
\hline Applied Geography & 1 & 1 & & & 1 & & & & & & 3 \\
\hline Area & & & & & & 1 & & & & & 1 \\
\hline Asia Pacific Viewpoint & & & & 1 & & & & & & & 1 \\
\hline Australian Geographer & 1 & & 1 & & & & & & & & 2 \\
\hline Environment and Planning $A$ & 1 & 1 & & & & & 1 & & & & 3 \\
\hline Environment and Planning $C$ & & & & & & & & 1 & & 2 & 3 \\
\hline Environment and Planning $D$ & & & & & & 1 & & & 2 & 1 & 4 \\
\hline Eurasian Geography and Economics & 1 & 1 & & & & & & & & & 2 \\
\hline European Planning Studies & & & & 3 & & & & & 1 & & 4 \\
\hline Geoforum & & & & & & & & & & 1 & 1 \\
\hline Geografiska Annaler-Series B: Human & & & & & & & & & 1 & & 1 \\
\hline \multicolumn{12}{|l|}{ Geography } \\
\hline GeoJournal & 2 & & 1 & & 1 & 2 & 2 & 2 & 1 & & 11 \\
\hline Global Networks & & 3 & & 1 & & 1 & & & & & 5 \\
\hline $\begin{array}{l}\text { International Journal of Urban and Regional } \\
\text { Research }\end{array}$ & & & 2 & & 2 & & 1 & & & 1 & 6 \\
\hline $\begin{array}{l}\text { Tijdschrift voor Economische En Sociale } \\
\text { Geografie }\end{array}$ & & & 1 & & 1 & 1 & & 2 & 1 & 1 & 7 \\
\hline Papers in Regional Science & & & & & & & 1 & 1 & & & 2 \\
\hline Regional Studies & & 2 & & 1 & & 1 & 1 & & & & 5 \\
\hline The Professional Geographer & & 1 & & & & & & & & & 1 \\
\hline Urban Geography & 1 & & & & & & & & & & 1 \\
\hline Group B Total & 7 & 11 & 6 & 6 & 7 & 7 & 7 & 6 & 6 & 6 & 69 \\
\hline \multicolumn{12}{|l|}{$\begin{array}{l}\text { Group C } \\
\text { (transport but non-geography journals) }\end{array}$} \\
\hline Maritime Economics \& Logistics & 11 & 13 & 11 & 13 & 12 & 12 & 12 & 13 & 34 & 15 & 146 \\
\hline Maritime Policy \& Management & 6 & 21 & 22 & 20 & 17 & 17 & 23 & 33 & 33 & 32 & 224 \\
\hline Shipping and Trade & & & & & & & & 7 & 2 & 3 & 12 \\
\hline Journal of Transport Economics and Policy & 3 & 2 & 3 & 1 & 1 & & & & & & 10 \\
\hline Transport Policy & 2 & 1 & 3 & 5 & 7 & 8 & 4 & 4 & 5 & 5 & 44 \\
\hline Transportation Research Part A & 1 & & 1 & 3 & 4 & 4 & 9 & 5 & 12 & 7 & 46 \\
\hline Transportation Research Part B & 1 & & 1 & 2 & 1 & & 2 & 8 & 7 & 5 & 27 \\
\hline Transportation Research Part D & 1 & 2 & & 3 & 8 & & 4 & 2 & 12 & 13 & 45 \\
\hline Transportation Research Part E & 5 & 8 & 16 & 4 & 8 & 13 & 12 & 17 & 17 & 8 & 108 \\
\hline Transport Reviews & 3 & 5 & 3 & 7 & & 5 & 3 & 3 & 2 & 5 & 36 \\
\hline Group C Total & 33 & 52 & 60 & 58 & 58 & 59 & 69 & 92 & 124 & 93 & 697 \\
\hline
\end{tabular}




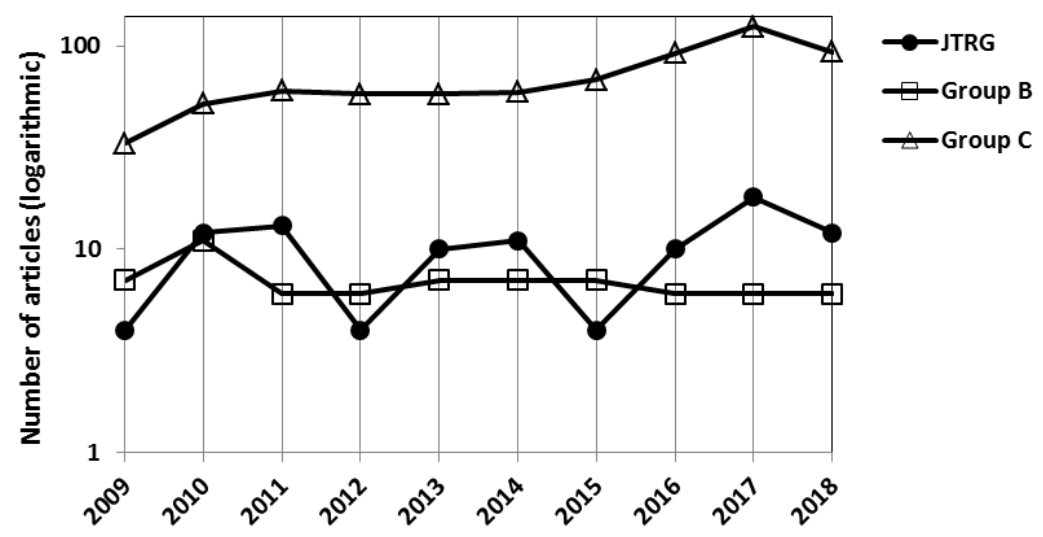

Fig. 1. Time history of port articles featured in three journal groups between 2009 and June 2018 (JTRG: Journal of Transport Geography; Group B: geography journals; Group C: transport but nongeography journals) 


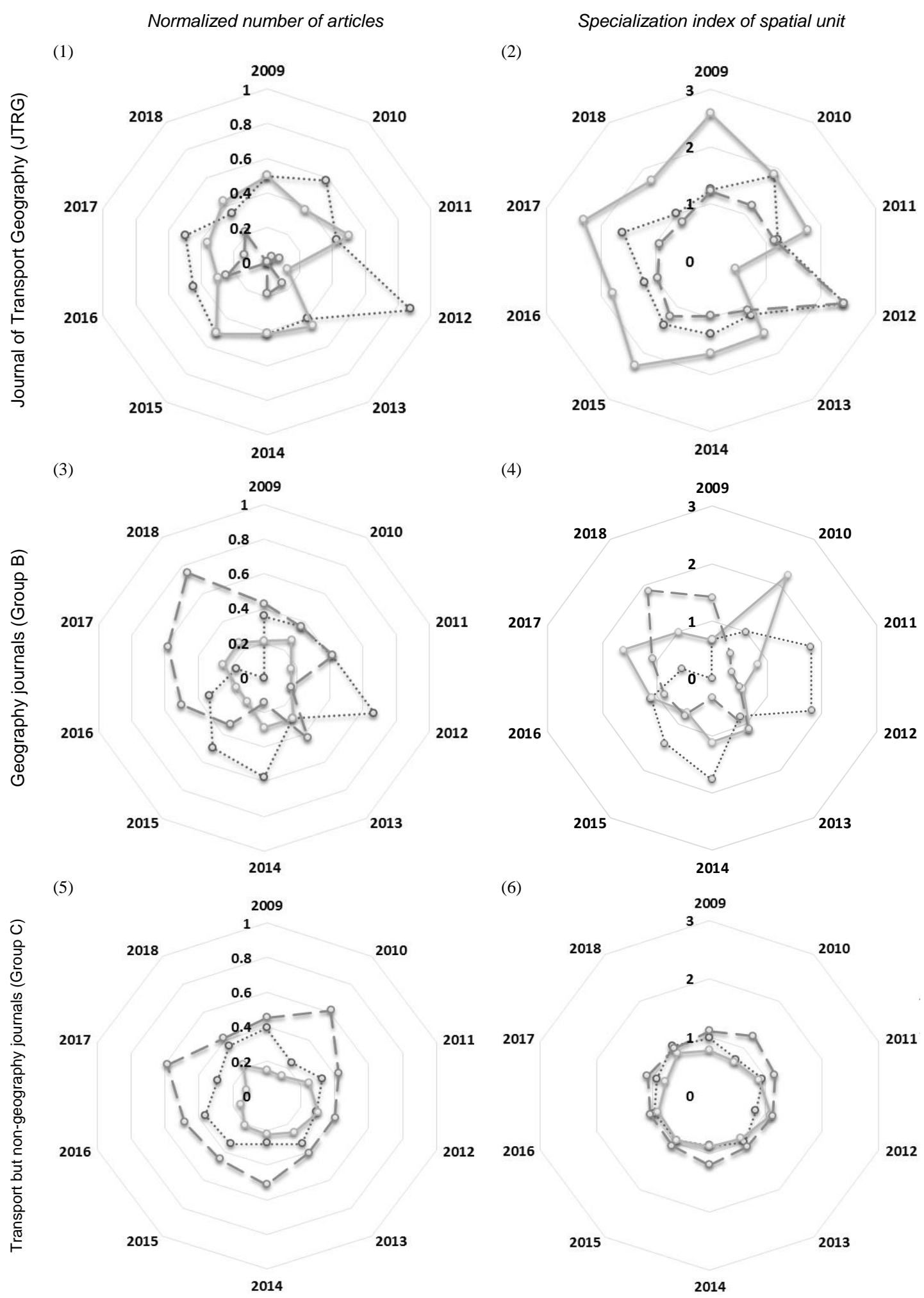

Fig. 2. Radar distribution of articles in each spatial unit in three journal groups between 2009 and June 2018; Round dot: Foreland \& maritime space (1), solid: Hinterland (2), dash: Port (3) 


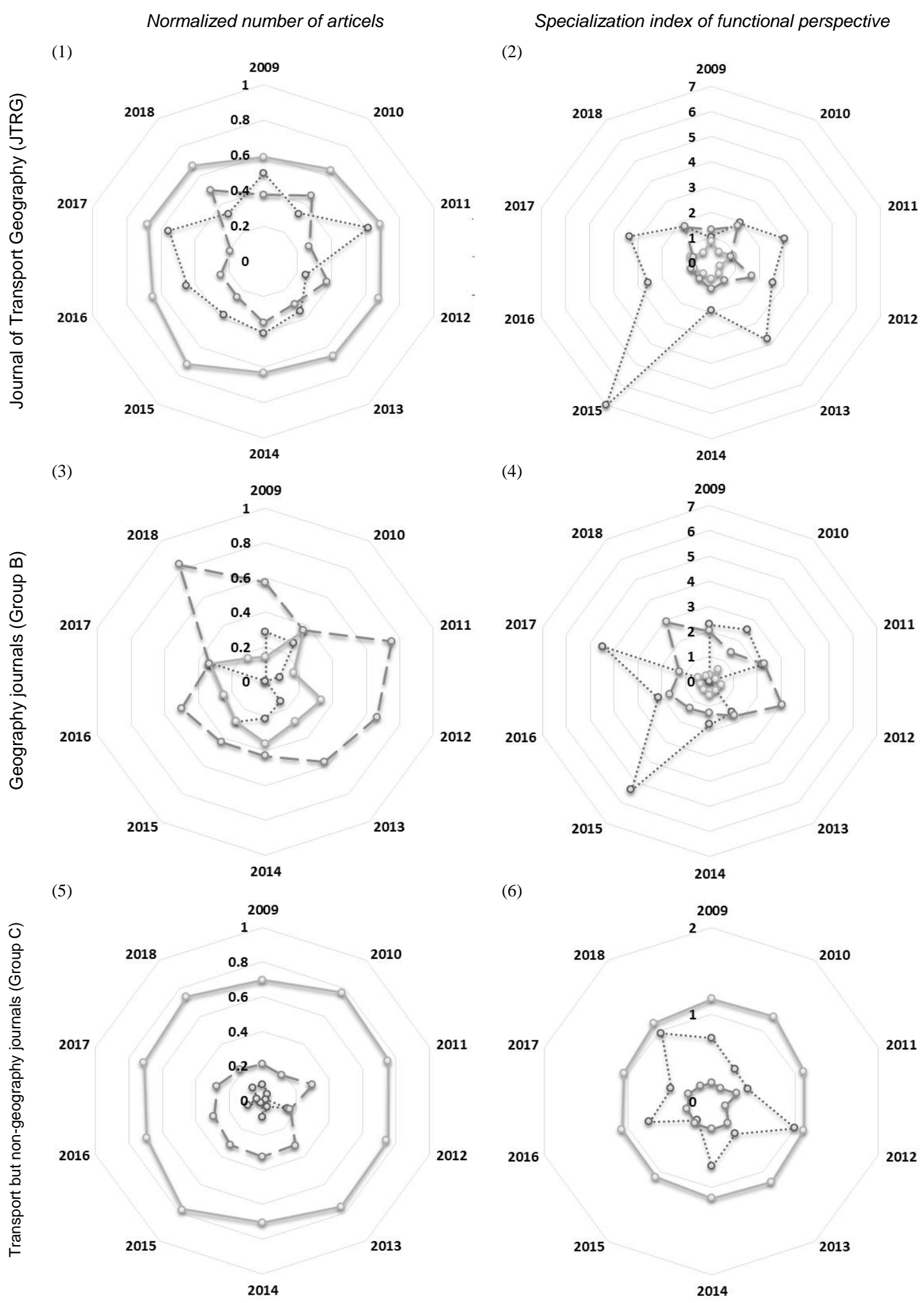

Fig. 3. Radar distribution of articles in each functional perspective in three journal groups between 2009 and June 2018;

Round dot: Locational $(1.1+2.1+3.1)$, solid: Operation $(1.2+2.2+3.2)$, dash: Impact $(1.3+2.3+3.3)$ 


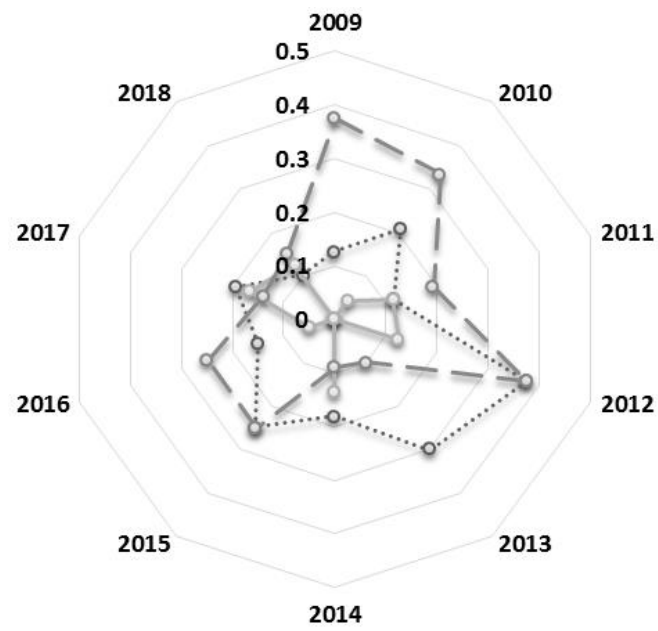

Journal of Transport Geography (JTRG)

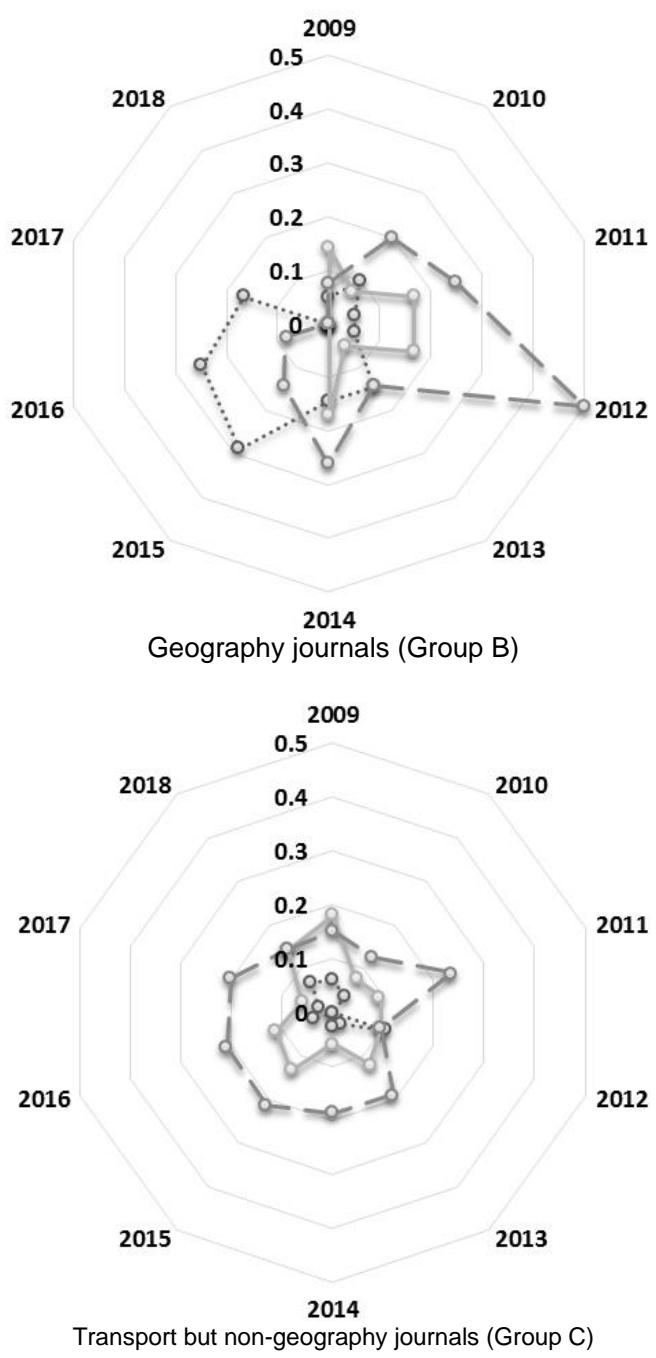

Fig. 4. Radar distribution of the normalized functional perspective of articles in global unit in three journal groups between 2009 and June 2018;

Round dot: Locational (1.1), solid: Operation (1.2), dash: Impact (1.3) 


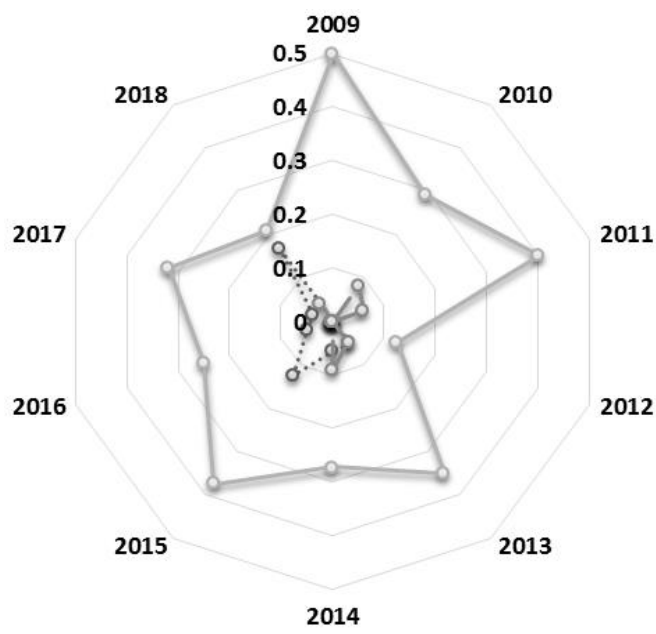

Journal of Transport Geography (JTRG)

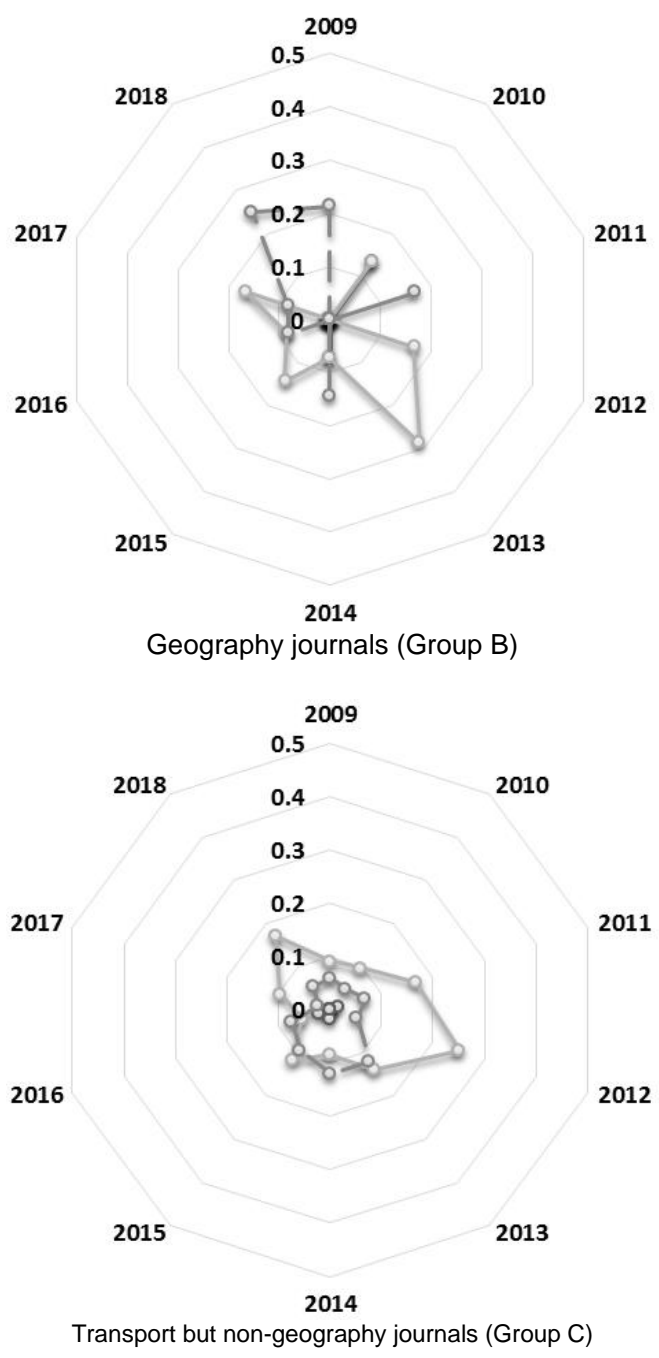

Fig. 5. Radar distribution of the normalized functional perspective of articles in regional/national unit in three journal groups between 2009 and June 2018;

Round dot: Locational (2.1), solid: Operation (2.2), dash: Impact (2.3) 


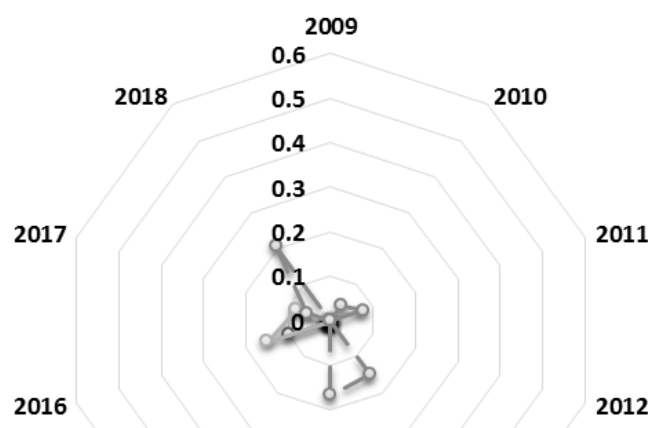

2015

2013

2014

Journal of Transport Geography (JTRG)

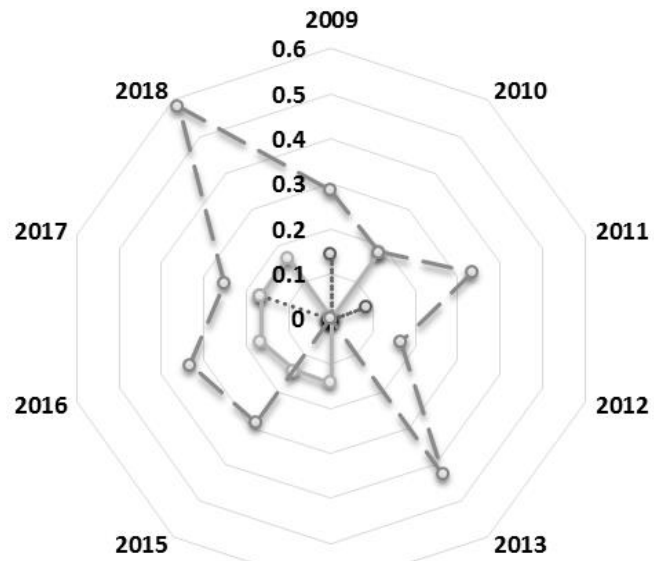

2014

Geography journals (Group B)

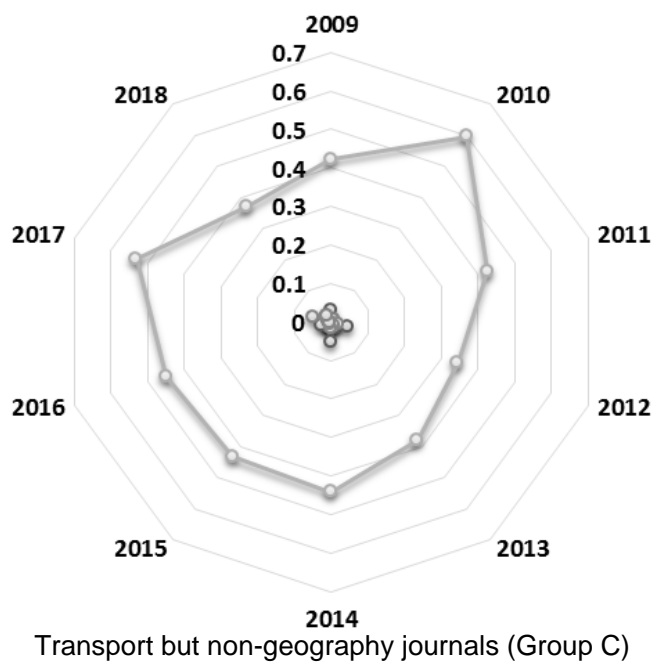

Fig. 6. Radar distribution of the normalized functional perspective of articles in local spatial unit in three journal groups between 2009 and June 2018;

Round dot: Locational (3.1), solid: Operation (3.2), dash: Impact (3.3) 


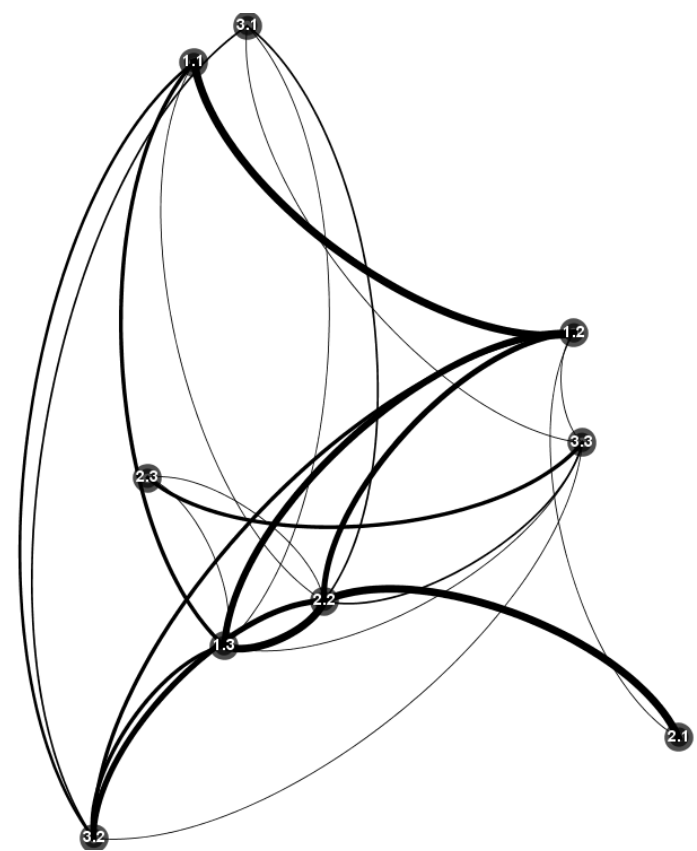

Fig. 7. Interrelation among articles featured in different spatial units and functional perspectives

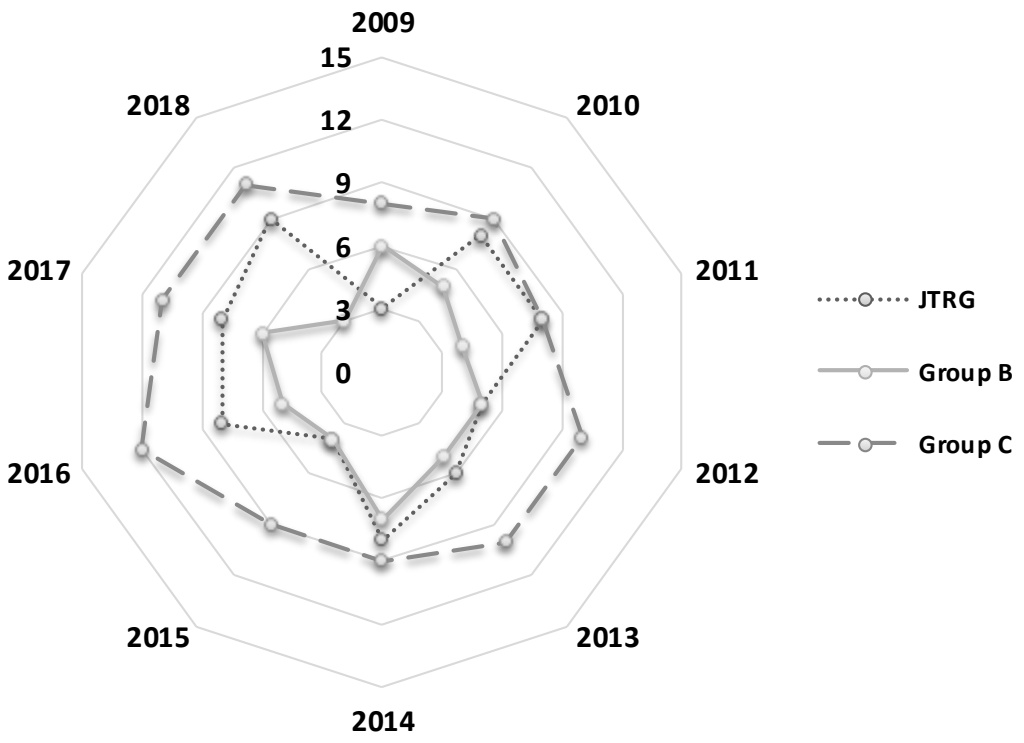

Fig. 8. Radar distribution of the total number of areas covered by three journal groups between 2009 and June 2018 (JTRG: Journal of Transport Geography; Group B: geography journals; Group C: transport but non-geography journals) 


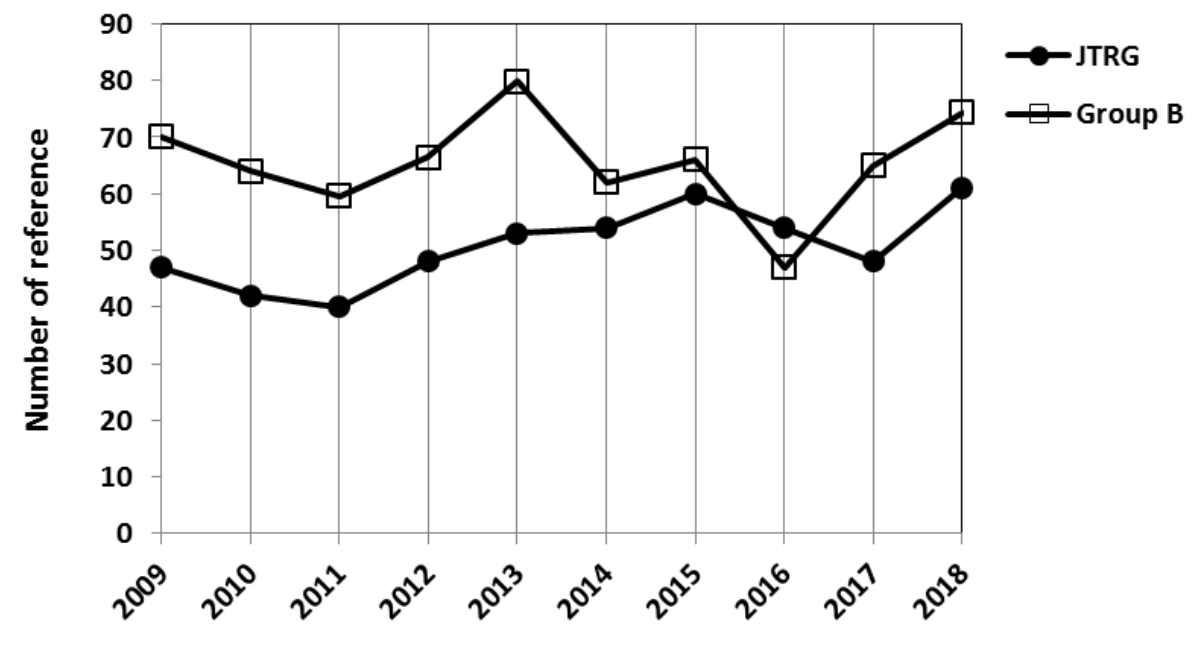

Fig. 9. Time history of the average number of references per article featured in two journal groups between 2009 and June 2018 (JTRG: Journal of Transport Geography; Group B: geography journals)

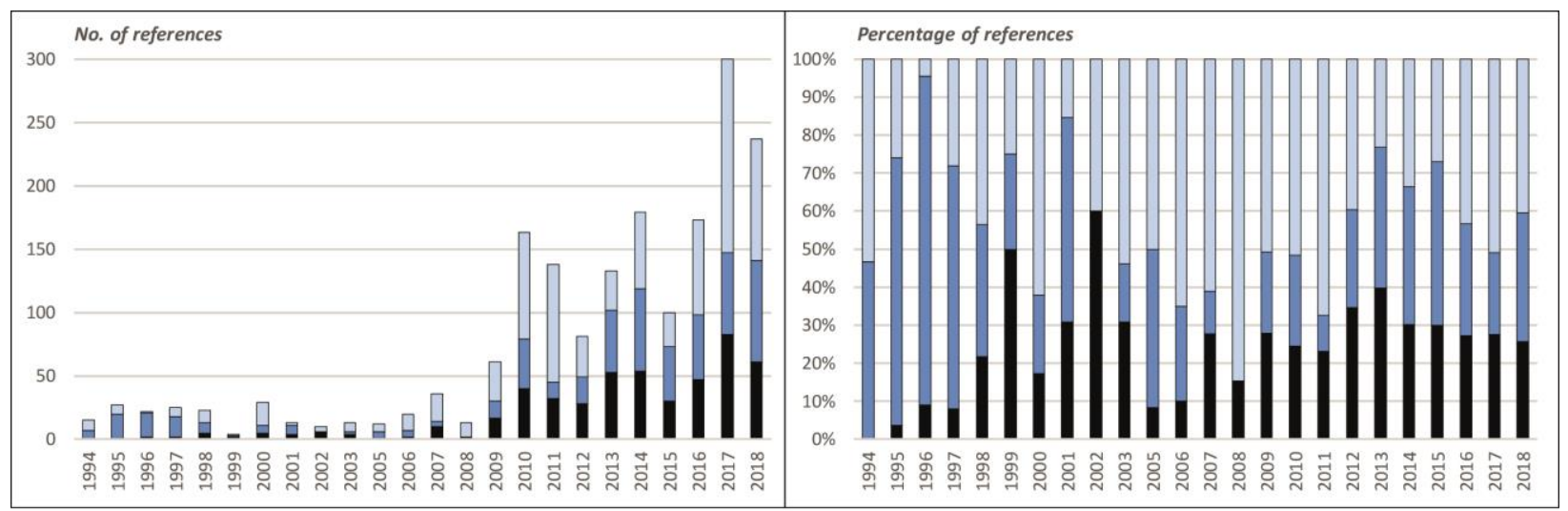

-Group A (transport) $\square$ Group B (JTRG) $\square$ Group C (geography)

Fig. 10. Distribution of JTRG articles' references per journal groups between 1994 and June 2018 (JTRG: Journal of Transport Geography; Group B: geography journals; Group C: transport journals) 

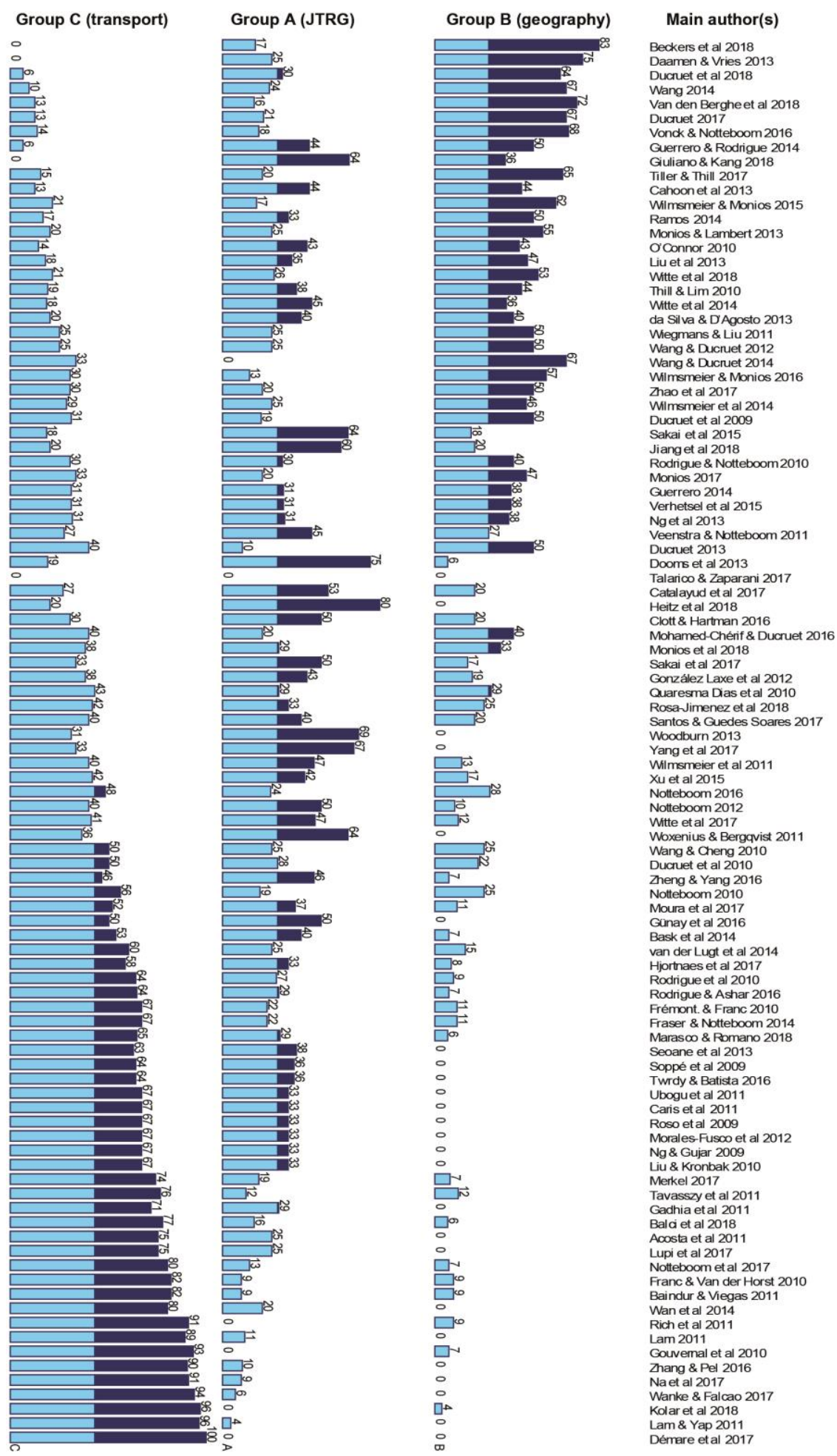

Fig. 11. Distribution of JTRG articles' references per article and journal groups between 2009 and June 2018 (Unit: \%)

N.B. dark colors refer to percentages higher than column average; each line equals to $100 \%$ 
Appendix I: List of Port Articles from 2009-June2018 in three groups (Journal of Transport Geography (JTG/ Group A), geography journals (Group B) and transport but non-geography journals (Group C)

\section{Group A}

Acosta, M., Coronado, D., Cerban, M.D.L., 2011. Bunkering competition and competitiveness at the ports of the Gibraltar Strait. J. Transp. Geogr. 19, 911-916.

Baindur., D., Viegas, J.M., 2011. An agent-based model concept for assessing modal share in interregional freight transport markets. J. Transp. Geogr. 19, 1093-1105.

Balci, G., Cetin, I.B., Esmer, S., 2018. An evaluation of competition and selection criteria between dry bulk terminals in Izmir. J. Transp. Geogr. 69, 294-304.

Bask, A., Roso, V., Andersson, D., Hämäläinen, E. 2014. Development of seaport-dry port dyads:

Two cases from Northern Europe. Journal of Transport Geography, 39(July 2014), 85-95.

Beckers, J., Vanhoof, M., Verhetsel, A., Returning the particular: Understanding hierarchies in the Belgian logistics system. J. Transp. Geogr. In press.

Berghe, K.V., Jacobs, W., Boelens, L., 2018. The relational geometry of the port-city interface: Case studies of Amsterdam, the Netherlands, and Ghent, Belgium. J. Transp. Geogr. 70, 5563.

Cahoon, S., Pateman, H., Chen, S.L., 2013. Regional port authorities: leading players in innovation networks? J. Transp. Geogr. 27, 66-75.

Calatayud, A., Mangan, J., Palacin, R., 2017. Connectivity to international markets: A multilayered network approach. J. Transp. Geogr. 61, 61-71.

Caris, A., Macharis, C., Janssens, G.K., 2011. Network analysis of container barge transport in the port of Antwerp by means of simulation. J. Transp. Geogr. 19, 125-133.

Clott, C., Hartman, B.C., 2016. Supply chain integration, landside operations and port accessibility in metropolitan Chicago. J. Transp. Geogr. 51, 130-139.

Daamen, T.A., Vries, I., 2013. Governing the European port-city interface: institutional impacts on spatial projects between city and port. J. Transp. Geogr. 27, 4-13.

Da Silva, M.A.V., De Almeida D'agosto, M. 2013. A model to estimate the origin-destination matrix for soybean exportation in Brazil. Journal of Transport Geography, 26, 97-107.

Démare, T., Bertelle, C., Dutot, A., Lévêque, L., 2017. Modeling logistic systems with an agentbased model and dynamic graphs. J. Transp. Geogr. 62, 51-65.

Dooms, M., Verbeke, A., Haezendonck, E., 2013. Stakeholder management and path dependence in large-scale transport infrastructure development: the port of Antwerp case (1960-2010). J. Transp. Geogr. 27, 14-25.

Ducruet, C., 2013. Network diversity and maritime flows. J. Transp. Geogr. 30, 77-88.

Ducruet, C., 2017. Multilayer dynamics of complex spatial networks: The case of global maritime flows (1977-2008). J. Transp. Geogr. 60, 47-58.

Ducruet, C., Cuyala, S., El Hosni, A., 2018. Maritime networks as systems of cities: The longterm interdependencies between global shipping flows and urban development (1890-2010). J. Transp. Geogr. 66, 340-355.

Ducruet, C., Rozenblat, C., Zaidi, F., 2010. Ports in multi-level maritime networks: evidence from the Atlantic (1996-2006). J. Transp. Geogr. 18, 508-518.

Ducruet, C., Roussin, S., Jo, J.C., 2009. Going West? Spatial polarization of the North Korean port system. J. Transp. Geogr. 17, 357-368.

Franc, P., Van der Horst, M., 2010. Understanding hinterland service integration by shipping lines and terminal operators: a theoretical and empirical analysis. J. Transp. Geogr. 18, 557-566. 
Fraser, D., Notteboom, T., 2014. A strategic appraisal of the attractiveness of seaport-based transport corridors: the Southern African case. J. Transp. Geogr. 36, 53-68.

Frémont, A., Fran, P. 2010. Hinterland transportation in Europe: Combined transport versus road transport. Journal of Transport Geography, 18(4), 548-556.

Gadhia, H.K., Kotzab, H., Prockl, G., 2011. Levels of internationalization in the container shipping industry: an assessment of the port networks of the large container shipping companies. J. Transp. Geogr. 19, 1431-1442.

Giuliano, G., Kang, S., 2018. Spatial dynamics of the logistics industry: Evidence from California. J. Transp. Geogr. 66, 248-258.

Gouvernal, E., Slack, B., Franc, P., 2010. Short sea and deep sea shipping markets in France. J. Transp. Geogr. 18, 97-103.

Guerrero, D., 2014. Deep-sea hinterlands: Some empirical evidence of the spatial impact of containerization. J. Transp. Geogr. 35, 84-94.

Guerrero, D., Rodrigue, J.P., 2014. The waves of containerization: shifts in global maritime transportation. J. Transp. Geogr. 34, 151-164.

Günay, G., Ergün, G., Gökaşar, I., 2016. Conditional Freight Trip Generation modeling. J. Transp. Geogr. 54, 102-111.

Heitz, A., Dablanc, L., Olsson, J., Sanchez-Diaz, I., Woxenius, J., Spatial patterns of logistics facilities in Gothenburg, Sweden. J. Transp. Geogr. In press.

Hjortnaes, T., Wiegmans, B., Negenborn, R.R., Zuidwijk, R.A., Klijnhout, R., 2017. Minimizing cost of empty container repositioning in port hinterlands, while taking repair operations into account. J. Transp. Geogr. 58, 209-219.

Jiang, Y., Lu, J., Cai, Y., Zeng, Q., Analysis of the impacts of different modes of governance on inland waterway transport development on the Pearl River: The Yangtze River. J. Transp. Geogr. In press.

Kolar, P., Schramm, H.J., Prockl, G., 2018. Intermodal transport and repositioning of empty containers in Central and Eastern Europe hinterland. J. Transp. Geogr. 69, 73-82.

Lam, J.S.L., 2011. Patterns of maritime supply chains: slot capacity analysis. J. Transp. Geogr. 19, 366-374.

Lam, J.S.L., Yap, W.Y., 2011. Dynamics of liner shipping network and port connectivity in supply chain systems: analysis on East Asia. J. Transp. Geogr.19, 1272-1281.

Laxe, F.G., Seoane, M.J.F., Montes, C.P., 2012. Maritime degree, centrality and vulnerability: port hierarchies and emerging areas in containerized transport (2008-2010). J. Transp. Geogr. 24, 33-44.

Liu, L., Wang, K.Y., Yip, T.L., 2013. Development of a container port system in Pearl River Delta: path to multi-gateway ports. J. Transp. Geogr. 28, 30-38.

Liu, M., Kronbak, J., 2010. The potential economic viability of using the Northern Sea Route (NSR) as an alternative route between Asia and Europe. J. Transp. Geogr. 18, 434-444.

Lupi, M., Farina, A., Orsi, D., Pratelli, A., 2017. The capability of Motorways of the Sea of being competitive against road transport. The case of the Italian mainland and Sicily. J. Transp. Geogr. 58, 9-21.

Marasco, A., Romano, A., 2018. Inter-port interactions in the Le Havre-Hamburg range: A scenario analysis using a nonautonomous Lotka Volterra model. J. Transp. Geogr. 69, 207220.

Mengqiao, X., Zhenfu, L., Yanlei, S., Xiaoling, Z., Shufei, J., 2015. Evolution of regional inequality in the global shipping network. J. Transp. Geogr. 44, 1-12. 
Merkel, A., 2017. Spatial competition and complementarity in European port regions. J. Transp. Geogr. 61, 40-47.

Mohamed-Chérif, F., Ducruet, C., 2016. Regional integration and maritime connectivity across the Maghreb seaport system. J. Transp. Geogr. 51, 280-293.

Monios, J., 2017. Cascading feeder vessels and the rationalisation of small container ports. J. Transp. Geogr. 59, 88-99.

Monios, J., Bergqvist, R., Woxenius, J., 2018. Port-centric cities: The role of freight distribution in defining the port-city relationship. J. Transp. Geogr. 66, 53-64.

Monios, J., Lambert, B., 2013. The Heartland Intermodal Corridor: public private partnerships and the transformation of institutional settings. J. Transp. Geogr. 27, 36-45.

Morales-Fusco, P., Saurí, S., Lago, A., 2012. Potential freight distribution improvements using motorways of the sea. J. Transp. Geogr. 24, 1-11.

Na, J.H., Choi, A.Y., Ji, J., Zhang, D., 2017. Environmental efficiency analysis of Chinese container ports with $\mathrm{CO} 2$ emissions: An inseparable input-output SBM model. J. Transp. Geogr. 65, 13-24.

Ng, K.Y.A., Gujar, G.C., 2009. The spatial characteristics of inland transport hubs: evidences from Southern India. J. Transp. Geogr. 17, 346-356.

Ng, A.K.Y., Padilha, F., Pallis, A.A., 2013. Institutions, bureaucratic and logistical roles of dry ports: the Brazilian experiences. J. Transp. Geogr. 27, 46-55.

Notteboom, T., 2010. Concentration and the formation of multi-port gateway regions in the European container port system: an update. J. Transp. Geogr. 18, 567-583.

Notteboom, T.E., 2012. Towards a new intermediate hub region in container shipping? Relay and interlining via the Cape route vs. the Suez route. J. Transp. Geogr. 22, 164-178.

Notteboom, T.E. 2016. The adaptive capacity of container ports in an era of mega vessels: The case of upstream seaports Antwerp and Hamburg. J. Transp. Geogr. 54(C), 295-309.

Notteboom, T.E., Parola, F., Satta, G., Pallis, A.A., 2017. The relationship between port choice and terminal involvement of alliance members in container shipping. J. Transp. Geogr. 64, $158-173$.

O'Connor, K., 2010. Global city regions and the location of logistics activity. J. Transp. Geogr. 18, 354-362.

Quaresma Dias, J.C., Calado, J.M.F., Mendonça, M.C., 2010. The role of European «ro-ro» port terminals in the automotive supply chain management. J. Transp. Geogr. 18, 116-124.

Ramos, S. 2014. Planning for competitive port expansion on the U.S. Eastern Seaboard: The case of the Savannah Harbor Expansion Project. J. Transp. Geogr. 36, 32-41.

Rich, J., Kveiborg, O., Hansen, C.O., 2011. On structural inelasticity of modal substitution in freight transport. J. Transp. Geogr. 19, 134-146.

Rodrigue, J.P., Ashar, A., 2016. Transshipment hubs in the New Panamax Era: The role of the Caribbean. J. Transp. Geogr. 51, 270-279.

Rodrigue, J.P., Debrie, J., Fremont, A., Gouvernal, E., 2010. Functions and actors of inland ports: European and North American dynamics. J. Transp. Geogr. 18, 519-529.

Rodrigue, J.P., Notteboom, T., 2010. Comparative North American and European gateway logistics: the regionalism of freight distribution. J. Transp. Geogr. 18, 497-507.

Rosa-Jiménez, C., Perea-Medina, B., Andrade, M.J., Nebot, N., 2018. An examination of the territorial imbalance of the cruising activity in the main Mediterranean port destinations: Effects on sustainable transport. J. Transp. Geogr. 68, 94-101. 
Roso, V., Woxenius, J., Lumsden, K., 2009. The dry port concept: connecting container seaports with the hinterland. J. Transp. Geogr. 17, 338-345.

Sakai, T., Kawamura, K., Hyodo, T., 2015. Locational dynamics of logistics facilities: Evidence from Tokyo. J. Transp. Geogr. 46, 10-19.

Sakai, T., Kawamura, K., Hyodo, T., 2017. Spatial reorganization of urban logistics system and its impacts: Case of Tokyo. J. Transp. Geogr. 60, 110-118.

Santos, T.A., Soares, C.G., 2017. Development dynamics of the Portuguese range as a multi-port gateway system. J. Transp. Geogr.60, 178-188.

Seoane, M.J.F., Laxe, F.G., Montes, C.P., 2013. Foreland determination for containership and general cargo ports in Europe (2007-2011). J. Transp. Geogr. 30, 56-67.

Soppé, M., Parola, F., Frémont, A., 2009. Emerging inter-industry partnerships between shipping lines and stevedores: from rivalry to cooperation? J. Transp. Geogr. 17, 10-12.

Talarico, L., Zamparini, L., 2017. Intermodal transport and international flows of illicit substances: Geographical analysis of smuggled goods in Italy. J. Transp. Geogr. 60, 1-10.

Tavasszy, L., Minderhoud, M., Perrin, J.F., Notteboom, T., 2011. A strategic network choice model for global container flows: specification, estimation and application. J. Transp. Geogr. 19, 1163-1172.

Thill, J.C., Lim, H., 2010. Intermodal containerized shipping in foreign trade and regional accessibility advantages. J. Transp. Geogr. 18, 530-547.

Tiller, K.C., Thill, J.C., 2017. Spatial patterns of landside trade impedance in containerized South American exports. J. Transp. Geogr. 58, 272-285.

Twrdy, E., Batista, M., 2016. Modeling of container throughput in Northern Adriatic ports over the period 1990-2013. J. Transp. Geogr. 52, 131-142,

Ubogu, A.E., Ariyo, J.A., Mamman, M., 2011. Port-hinterland trucking constraints in Nigeria. J. Transp. Geogr. 19, 106-114.

Van der Lugt, L.M., Rodrigues, S.B., Van den Berg, R., 2014. Co-evolution of the strategic reorientation of port actors: insights from the Port of Rotterdam and the Port of Barcelona. J. Transp. Geogr. 41, 197-209.

Veenstra, A., Notteboom, T., 2011. The development of the Yangtze River container port system. J. Transp. Geogr. 19, 772-781.

Verhetsel, A., Kessels, R., Goos, P., Zijlstra, T., Blomme, N., Cant, J., 2015. Location of logistics companies: a stated preference study to disentangle the impact of accessibility. J. Transp. Geogr. 42, 110-121.

Vonck, I., Notteboom, T., 2016. Panarchy within a port setting. J. Transp. Geogr. 51, 208-315.

Wan, Z., Zhang, Y., Wang, X., Chen, J., 2014. Policy and politics behind Shanghai's Free Trade Zone Program. J. Transp. Geogr. 34, 1-6.

Wang, H., 2014. Preliminary investigation of waterfront redevelopment in Chinese coastal port cities: the case of the eastern Dalian port areas. J. Transp. Geogr. 40, 29-42.

Wang, C., Ducruet, C., 2012. New port development and global city making: emergence of the Shanghai-Yangshan multilayered gateway hub. J. Transp. Geogr. 25, 58-69.

Wang, C., Ducruet, C., 2014. Transport corridors and regional balance in China: the case of coal trade and logistics. J. Transp. Geogr. 40, 3-16.

Wang, J.J., Cheng, M.C., 2010. From a hub port city to a global supply chain management center: a case study of Hong Kong. J. Transp. Geogr. 18, 104-115.

Wanke, P., Falcão, B.B., 2017. Cargo allocation in Brazilian ports: An analysis through fuzzy logic and social networks. J. Transp. Geogr. 60, 33-46. 
Wiegmans, B.W., Louw, E., 2011. Changing port-city relations at Amsterdam: A new phase at the interface? J. Transp. Geogr. 19, 575-583.

Wilmsmeier, G., Monios, J., 2015. The production of capitalist "smooth" space in global port operations. J. Transp. Geogr. 47, 59-69.

Wilmsmeier, G., Monios, J., Lambert, B., 2011. The directional development of intermodal freight corridors in relation to inland terminals. J. Transp. Geogr. 19, 1379-1386.

Wilmsmeier, G., Monios, J., Pérez-Salas, G., 2014. Port system evolution - the case of Latin America and the Caribbean. J. Transp. Geogr. 39, 208-221.

Wilmsmeier, G., Monios, J., 2016. Institutional structure and agency in the governance of spatial diversification of port system evolution in Latin America. J. Transp. Geogr. 51, 294-307.

Witte, P., Slack, B., Keesman, M., Jugie, J.H., Wiegmans, B., Facilitating start-ups in port-city innovation ecosystems: A case study of Montreal and Rotterdam. J. Transp. Geogr. In press.

Witte, P.A., Wiegmans, B., Rodrigue, J. (2017). Competition or Complementarity in Dutch Inland

Port Development: A Case of Overproximity? J. Transp. Geogr. 60, 80-6923.

Witte, P., Wiegmans, B., Van Oort, F., Spit, T., 2014. Governing inland ports: a multi-dimensional approach to addressing inland port-city challenges in European transport corridors. J. Transp. Geogr. 36, 42-52.

Woodburn, A. 2013. Effects of rail network enhancement on port hinterland container activity: A United Kingdom case study. J. Transp. Geogr. 33, 162-169.

Woxenius, J., Bergqvist, R., 2011. Comparing maritime containers and semi-trailers in the context of hinterland transport by rail. J. Transp. Geogr. 19, 680-688.

Yang, D., Wang, K.Y., Xu, H., Zhang, Z. 2017. Path to a multilayered transshipment port system: How the Yangtze River bulk port system has evolved. J. Transp. Geogr. 64, 54-64.

Zanon Moura, T., Garcia-Alonso, L., Salas-medo, M. 2017. Delimiting the scope of the hinterland of ports: Proposal and case study. J. Transp. Geogr. 65, 35.

Zhang, M., Pel, A.J., 2016. Synchromodal hinterland freight transport: Model study for the port of Rotterdam. J. Transp. Geogr. 52, 1-10.

Zhao, Q., Xu, H., Wall, R.S., Stavropoulos, S., 2017. Building a bridge between port and city: Improving the urban competitiveness of port cities. J. Transp. Geogr. 59, 120-133.

Zheng, J., Yang, D., 2016. Hub-and-spoke network design for container shipping along the Yangtze River. J. Transp. Geogr. 55, 51-57.

\section{Group B}

Akinyemi, Y. (2016). Port reform in Nigeria: Efficiency gains and challenges. GeoJournal. 81(5), 681-697.

Antoine, S., Sillig, C., Ghiara, H., 2017. Advanced logistic in Italy: A city network analysis. Tijdschrift voor Economische En Sociale Geografie, 108(6), 753-767.

Bai, X., Lam, J.S.L., 2015. Dynamic regional port cluster development: case of the ports across Taiwan Strait. Geojournal, 80, 619-636.

Blok, A., Tschötschel, R., 2016. World port cities as cosmopolitan risk community: Mapping urban climate policy experiments in Europe and East Asia. Environ. Plan C. 34, 717-736.

Castillo-Manzano, J.I., Fageda, X., 2014. How are investments allocated in a publicly owned port system? Political factors versus Economic Criteria. Reg. Stud. 48(7), 1279-1294.

Cassey, A.J., Schmeiser, K.N., 2013. The agglomeration of exporters by destination. Ann. Reg. Sci. 51(2), 495-513. 
Cidell, J., 2011. Distribution Centers among the Rooftops: The Global Logistics Network Meets the Suburban Spatial Imaginary. Int. J. Urban Regional. Res. 35(4): 835-851.

Cowen, D., 2010. A geography of logistics: market authority and the security of supply chains. Ann. Assoc. Am. Geogr. 100(3), 600-620.

Daamen, T.A., Louw, E., 2016. The challenge of the Dutch port-city interface. Tijdschrift voor Economische En Sociale Geografie, 107(5), 642-651.

Dembski, S., 2013. In search of symbolic markers: Transforming the urbanized landscape of the Rotterdam Rijnmond.

Derudder, B., Witlox, F., 2010. World cities and global commodity chains: an introduction. Glob. Netw. 10(1), 1-11.

Doucet, B., 2013. Variations of the entrepreneurial city: goals, roles and visions in Rotterdam's Kop van Zuid and the Glasgow harbour megaprojects. Int. J. Urban Regional. Res. 37(6), 20352051.

Doucet, B., van Kempen, R., van Veesep, J., 2011. Resident perceptions of flagship waterfront regeneration: The case of the Koo Van Zuid in Rotterdam. Tijdschrift voor Economische En Sociale Geografie, 102(2), 125-145.

Ducruet, C., Koster, H.R.A., Van der Beek, D.J., 2010. Commodity Variety and Seaport Performance. Reg. Stud. 44(9): 1221-1240.

Ducruet, C., Itoh, H., Joly, O., 2015. Ports and the local embedding of commodity flows. Papers Reg. Sci. 94(3), 607-628.

Ducruet, C., Notteboom, T., 2012. The worldwide maritime network of container shipping: spatial structure and regional dynamics. Glob. Netw. 12(3), 395-423.

Fornahl, D., Hassink, R., Klaerding, C., Mossig, I., Schröder, H., 2012. From the old path of shipbuilding onto the new Path of offshore wind energy? The case of northern Germany. Eur. Plan. Stud. 20(5), 835-855.

Fraser, D.R., Notteboom, T., Ducruet, C., 2016. Peripherality in the global container shipping network: the case of the Southern African container port system. Geojournal 81, 139-151.

Hall, P.V., 2009. Container ports, local benefits and transportation worker Earnings. Geojournal. $74,67-83$.

Hall, P. Jacobs, W. (2010). Shifting proximities: The maritime ports sector in an era of global supply chains. Regional Studies, 44(9), 1103-1115.

Haughton, G., Allmendinger, P., 2015. Fluid spatial imaginaries: Evolving estuarial city-regional spaces, Int. J. Urban Reg. Res. 39(5), 857-873.

Hepworth, K., 2014. Enacting logistical geographies. Environ. Plan D. 32, 1120-1134.

Hesse, M., 2010. Cities, material flows and the geography of spatial interaction: urban places in the system of chains. Glob. Netw. 10(1), 475-491.

Hesse, M., 2018. Approaching the relational nature of the port-city interface in Europe: Ties and tensions between seaports and the urban. Tijdschrift voor Economische En Sociale Geografie, 109(2), 210-223.

Hill, D.P., 2012. Port reform, South Asian migrant workers and spaces of vulnerability in Port Klang, Malaysia. Asia Pac. Viewp. 53(2), 105-117.

Hönke, J., Cuesta-Fernandez, I., 2017. A topolographical approach to infrastructure: Political topography, topology and the port of Dar es Salaam. Environ. Plan D. 35(6), 1076-1095.

Jacobs, W., 2014. Rotterdam and Amsterdam as trading places? In search of the economic geographical nexus between global commodity chain and world cities. Tijdschrift voor Economische En Sociale Geografie, 105(4), 483-491. 
Jacobs, W., Ducruet, C., De Langen, P., 2010. Integrating world cities into production networks: the case of port cities. Glob. Netw. 10(1), 92-113.

Jacobs, W., Lagendijk, A., 2014. Strategic coupling as capacity: how seaports connect to global flows of containerized transport. Glob. Netw. 14(1), 44-62.

Jacobs, W., Notteboom, T. 2011. An Evolutionary Perspective on Regional Port Systems: The Role of Windows of Opportunity in Shaping Seaport Competition. Environ. Plan A, 43(7), 1674-1692.

Jaffee, D., 2015. A deeper channel floats all boats': the port economy as urban growth engine. Environ. Plan A. 47, 783-800.

Jaffee, D., Neoliberal urbanism as 'Strategic Coupling' to global chains: Port infrastructure and the role of economic impact studies. Environ. Plan C. In press.

Jing, N., Cai, W., 2010. Analysis on the spatial distribution of logistics industry in the developed East Coast Area in China. Ann. Reg. Sci. 45(2), 331-350.

Kaiser, M.F., 2009. Environmental changes, remote sensing, and infrastructure development: The case of Egypt's East Port Said harbor. Appl. Geogr. 29, 280-288.

Lee, S.W., Ducruet, C., 2009. Spatial glocalization in Asia-Pacific hub port cities: a comparison of Hong Kong and Singapore. Urabn Geogr. 30(2), 162-184.

Li, J.Y., Notteboom, T.E., Wang, J.J., 2017. An institutional analysis of the evolution of inland waterway transport and inland ports on the Pearl River. Geojournal. 82, 867-886.

Li, Z., Xu, M., Shi, Y., 2015. Centrality in global shipping network basing on worldwide shipping areas. Geojournal. 80, 47-60.

Márquez-Ramos, L., 2016. Port facilities, regional spillovers and exports: Empirical evidence from Spain. Papers Reg. Stud. 95(2), 329-352.

McArthur, J., Comparative infrastructural modalities: Examining spatial strategies for Melbourne, Auckland and Vancouver. Environ. Plan C. In press.

McCarthy, J.P., Romein, A., 2012. Cruise passenger terminals, spatial planning and regeneration: the cases of Amsterdam and Rotterdam. Eur. Plan. Stud. 20(12), 2033-2052.

Meyer, H., Nillesen, A.L., Zonneveld, W., 2012. Rotterdam: a city and a mainport on the edge of a delta. Eur. Plan. Stud. 21(1), 71-94.

Monios, J., Wang, Y., 2013. Spatial and institutional characteristics of inland port development in China. Geojournal. 78, 897-913.

Ng, A.K.Y., Cetin, I.B., 2012. Locational characteristics of dry ports in developing economies: Some lessons from Northern India. Reg. Stud. 46(6), 757-773.

$\mathrm{Ng}$, A.K.Y., Tongzon, J.L., 2009. The transportation sector of India's economy: dry ports as catalysts for regional development. Eurasian Geogr. Econ. 51(5), 669-682.

Notteboom, T.E., 2009. Complementarity and substitutability among adjacent gateway ports. Environ. Plan A. 41, 743-762.

Oakley, S., 2009. Governing urban waterfront renewal: the politics, opportunities and challenges for the inner harbour of Port Adelaide, Australia. Aust. Geogr. 40:3, 297-317.

Pan, K., Cao, Y., Liang, S, Wei, H., 2014. New tendency of Chinese container port system: 19982010 New tendency of Chinese container port system: 1998-2010. Geojournal. 79, 373-384.

Percoco, M., 2013. Geography, institutions and urban development: Italian cities, 1300-1861. Ann. Reg. Sci. 50(1), 135-152.

Potter, C., 2015. River of Traffic: The Spatial Fragmentation of US Ports. Reg Stud. 49(4), 14271440. 
Poulsen, R.T., Ponte, S., Sornn-Friese, H., 2018. Environmental upgrading in global value chains: The potential and limitations of ports in the greening of maritime transport. Geoforum. 89, 8395.

Raimbault, N., Jacobs, W., Van Dongen, F., 2016. Port regionalization from a relational perspective: The rise of Venlo as Dutch international logistic hub. Tijdschrift voor Economische En Sociale Geografie, 107(1), 16-32.

Rimmer, P.J., Comtois, C., 2009. China's container-related dynamics, 1990-2005. Geojournal. 74, 35-50.

Rodrigue, J.P., Notteboom, T., 2013. The geography of cruises: Itineraries, not destinations. Appl. Geogr. 38, 31-42.

Spence, E., 2014. Towards a more-than-sea geography: exploring the relational geographies of superrich mobility between sea, superyacht and shore in the Cote d'Azur. Area. 46(2), 203209.

Trumbull, N., Bodrov, O., 2009. Environmental Degradation of Russian Coastal Regions: Exploring the Gulf of Finland. Eurasian Geogr. Econ. 50(5): 591-605.

Wang, C., Ducruet, C., 2013. Regional resilience and spatial cycles: Long-term evolution of Chinese port system (221BC-2010AD). Tijdschrift voor Economische En Sociale Geografie, 104(5), 521-538.

Wang, J.J., Ng, A.K.Y., 2011. The geographical connectedness of Chinese seaports: a new trend? Tijdschrift voor Economische En Sociale Geografie, 102(2), 188-204.

Wei, Y.H.D., Luo, J., Zhou, Q., 2010. Location decisions and network configurations of foreign investment in urban China. Prof. Geogr. 62(2), 264-283.

Wheeler, P., Peterson, J., Gordon-Brown, L. 2010. Long-term bathymetric effects of groyne array emplacement at Lakes Entrance, Victoria, Australia. Appl. Geogr. 30(1), 126-140.

Widdis, R. 2011. "Across the Boundary in a Hundred Torrents": The Changing Geography of Marine Trade within the Great Lakes Borderland Region during the Nineteenth and Early Twentieth Centuries. Ann Am Assoc Geogr. 101(2), 356-379.

Wilmsmeier, G., Notteboom, T., 2011. Determinants of liner shipping network configuration: a two-region comparison. Geojournal. 76, 213-228.

Wilson, J., Bayo'n, M., 2017. Fantastical materializations: Interoceanic infrastructures in the Ecuadorian Amazon. Environ. Plan D. 35(5), 836-854.

$\mathrm{Wu}$, J., 2011. Between the centre and the periphery: the development of port trade in Darwin, Australia. Aust. Geogr. 42(3), 273-288.

Yliskylä-Peuralahti, J., 2017. Ecological modernization and the multi-scaled governance of sustainability in maritime transport. Geogr. Ann. B. 99(1), 42-58.

Yoon, J., Rhee, J., Dedahanov, A.T., 2017. The roles of networks among innovators in regional innovation: comparative analysis between China and South Korea. Eur. Plan. Stud. 25(5), 790804.

Ziadah, R., 2018. Transport infrastructure and logistic in the making of Dubai Inc. Int. J. Urban Reg. Res. 42(2), 182-197.

Ziadah, R., Constructing a logistics space: Perspectives from the Gulf Cooperation Council. Environ. Plan D. In press.

Zhu, S., He, C., 2014. Global, regional and local: new firm formation and spatial restructuring in China's apparel industry. Geojournal. 79, 237-253. 
Zviely, D., Bitan, M., Disegni, D.M. (2015).The effect of sea-level rise in the 21st century on marine structures along the Mediterranean coast of Israel: An evaluation of physical damage and adaptation cost. Appl. Geogr. 57(C), 154-162.

\section{Group C}

Acciaro, M., Ferrari, C., Lam, J.S.L., Macario, R., Roumboutsos, A., Sys, C., Tei, A., Vanelslander, T. 2018. Are the innovation processes in seaport terminal operations successful? Maritime Policy \& Management. 45(6), 787-802.

Acciaro, M., Vanelslander, T., Sys, C., Ferrari, C., Roumboutsos, A., Giuliano, G., Lam, J. S.L., Kapros, S.2014. Environmental sustainability in seaports: a framework for successful innovation. Maritime Policy \& Management. 41(5), 480-500.

Ahl, C., Frey, E., \& Steimetz, S. (2017). The effects of financial incentives on vessel speed reduction: Evidence from the port of long beach green flag incentive program. Maritime Economics \& Logistics, 19(4), 601-618

Alvarez, J.F., Longva, T., Engebrethsen, E. 2009. A methodology to assess vessel berthing and speed optimization policies. Maritime Economics and Logistics. 12(4), 327-346.

Alyami, H., Lee, P. T., Yang, Z., Riahi, R., Bonsall, S., Wang, J.2014. An advanced risk analysis approach for container port safety evaluation. Maritime Policy \& Management. 41(7), 634-650.

Ambrosino, D., Caballini, C., Siri, S. 2013. A mathematical model to evaluate different train loading and stacking policies in a container terminal. Maritime Economics and Logistics. 15(3), 292-308.

Ambrosino, D., Ferrari, C., Sciomachen, A., Tei, A. 2018. Ports, external costs, and Northern Italian transport network design: effects for the planned transformation. Maritime Policy \& Management. 45(6), 803-818.

Anderson, C.M., Opaluch, J.J., Grigalunas, T.A. 2009. The demand for import services at US container ports. Maritime Economics and Logistics. 11(2), 156 - 185.

Andersson, P., Ivehammar, P. 2017. Dynamic route planning in the Baltic Sea Region - A costbenefit analysis based on AIS data. Maritime Economics and Logistics. 9(4), 631-649.

Angelopoulos, J. 2017. Creating and assessing composite indicators: Dynamic applications for the port industry and seaborne trade. Maritime Economics and Logistics. 19(1), 126-159.

Angeloudis, P., Bell, M.G.H. 2010. An uncertainty-aware AGV assignment algorithm for automated container terminals. Transportation Research Part E. 46(3), 354-366.

Angeloudis, P., Bell, M.G. H. 2011. A review of container terminal simulation models. Maritime Policy \& Management. 38(5), 523-540.

Angeloudis, P., Greco, L., Bell, M. G.H.2016. Strategic maritime container service design in oligopolistic markets. Transportation Research Part B.90, 22-37.

Aperte, X.G, Baird, A. J. 2013 Motorways of the sea policy in Europe. Maritime Policy \& Management. 40(1), 10-26.

Apivatanagul, P., Regan, A.C. 2010. Long haul freight network design using shipper-carrier freight flow prediction: A California network improvement case study. Transportation Research Part E. 46(4), 507-519.

Arduino, G., Murillo, D.C., Parola, F. 2015. Refrigerated container versus bulk: evidence from the banana cold chain. Maritime Policy \& Management. 42(3), 228-245.

Aregall, M.G., Bergqvist, R., Monios, J. 2018. A global review of the hinterland dimension of green port strategies. Transportation Research Part D.59, 23-34.

Aronietis, R., Sys, C., Hassel, E., Vanelslander, T. 2016. Forecasting port-level demand for LNG as a ship fuel: the case of the port of Antwerp. Shipping and Trade. 1(2), 1-22. 
Aronietis, R., Sys, C., Hassel, E., Vanelslander, T. 2017. Investigating the bunkering choice determinants: the case of the port of Antwerp. Shipping and Trade. 2(8).

Artal-Tur, A., Gómez-Fuster, J.M., Navarro-Azorín, J.M., Ramos-Parreño, J. M.2016.Estimating the economic impact of a port through regional input-output tables: Case study of the Port of Cartagena (Spain). Maritme Economics and Logistics. 18(4), 371-390.

Asadabadi , A., Miller-Hooks, E. 2018.Co-opetition in enhancing global port network resiliency: A multi-leader, common-follower game theoretic approach. Transportation Research Part B.108, 281-298.

Asgar, N., Hassani, A., Jones, D., Nguye, H.H .2015.Sustainability ranking of the UK major ports: Methodology and case study. Transportation Research Part E. 78, 19-39.

Asgari, N., Farahani, R. Z., Goh, M. 2013. Network design approach for hub ports-shipping companies competition and cooperation. Transport Research Part A. 48, 1-8.

Asperen, E., Dekker, R. 2013.Centrality, flexibility and floating stocks: A quantitative evaluation of port-of-entry choices. Maritime Economics and Logistics. 15(1), 72-100.

Asteris, M., Collins, A. 2010. UK Container Port Investment and Competition: Impediments to the Market. Transport Reviews. 30(2), 163- 178.

Aydogdu, Y.V., 2015. A study on quantitative benefits of port community systems. Maritime Policy \& Management. 42(1), 1-10.

Álvarez-SanJaime, Ó., Cantos-Sánchez, P., Moner-Colonques, R., Sempere-Monerris, J.J. 2013. Vertical integration and exclusivities in maritime freight transport. Transportation Research Part B. 51, 50-61.

Álvarez-SanJaime, Ó., Cantos-Sánchez, P., Moner-Colonques, R., Sempere-Monerris, J.J. 2015. The impact on port competition of the integration of port and inland transport services. Transportation Research Part B. 80, 291-302.

Babu, S.A.K.I., Pratap, S., Lahoti, G., Fernandes, K.J., Tiwari, M.K., Mount, M., Xiong, Y. 2015.Minimizing delay of ships in bulk terminals by simultaneous ship scheduling, stockyard planning and train scheduling. Maritime Economics and Logistics. 17(1), 97-126.

Bae, M.J., Chew, E .P., Lee, L.H., Zhang, A.2013.Container transshipment and port competition. Maritime Policy \& Management. 40(5), 479-494.

Baindur, D., Viegas, J. 2011.Challenges to implementing motorways of the sea concept-lessons from the past. Maritime Policy \& Management. 38(7), 673- 690.

Bandara, Y.M., Nguyen, H. 2016. Influential factors in port infrastructure tariff formulation, implementation and revision. Transportation Research Part A. 85, 220-232.

Bandara, Y.M., Nguyen, H., Chen, S. 2016.Influential factors in the design of port infrastructure tariffs. Maritime Policy \& Management. 43(7), 830-842.

Barnes-Dabban, H., Koppen, K. V., Mol, A. 2018. Environmental reform of West and Central Africa ports: the influence of colonial legacies. Maritime Policy \& Management. 44(5), 565583.

Barros, C.P. 2016. Demand analysis in Angola seaports. 2016. Demand analysis in Angola seaports. 43(6), 676-682.

Barros, C.P., Chen, Z., Wanke, P. 2016. Efficiency in Chinese seaports: 2002-2012. Maritme Economics and Logistics 18(3), 295-316.

Barros, C.P., Felício, J. A., Fernandes, R.L. 2011. Productivity analysis of Brazilian seaports. Maritime Policy \& Management. 39(5), 503- 523.

Bartholdi, J.J., Jarumaneeroj, P., Ramudhin,A. 2016. A new connectivity index for container ports. Maritme Economics and Logistics. 18(3), 231-249. 
Bensassi, S., Márquez-Ramos, L., Martínez-Zarzoso, I., Suárez-Burguet, C. 2015.Relationship between logistics infrastructure and trade: Evidence from Spanish regional exports. Transportation Research Part A. 72, 47-61.

Bensassi, S., Martinez-Zarzoso, I., Suárez, C. 2014.The effect of maritime transport costs on the extensive and intensive margins: Evidence from the Europe-Asia trade. Maritime Economics and Logistics 16(3), 276-297.

Berle, Ø., Rice Jr.J.B., Asbjørnslett, B.E. 2011.Failure modes in the maritime transportation system: a functional approach to throughput vulnerability. Maritime Policy \& Management. 38(6), 605- 632.

Berechman, J., Tseng, P. 2012. Estimating the environmental costs of port related emissions: The case of Kaohsiung. Transport Research Part D. 17(1), 35-38.

Berg, R.V., Langen, P.W. D. 2015.Towards an 'inland terminal centred' value proposition. Maritime Policy \& Management. 42(5), 499-515.

Bergantino, A.S., Musso, E. 2011. The role of external factors versus managerial ability in determining seaports' relative efficiency: An input-by-input analysis through a multi-step approach on a panel of Southern European Port. Maritime Economics and Logistics. 13(2), 121141.

Beresford, A., Pettit, S., Xu, Q., Williams, S. 2012. A study of dry port development in China. Economics and Logistics. 14(1), 73-98.

Beuren, M.M., Andriotti, R., Vieira, G.B.B., Ribeiro, J. L.D., Neto, F.J.K. 2018. On measuring the efficiency of Brazilian ports and their management models. Maritime Economics and Logistics, 20(1), 149-168.

Bhadury, J. 2016. Panama Canal expansion and its impact on East and Gulf coast ports of U.S.A. Maritime Policy \& Management. 43(8), 928-944.

Bichou, K. 2011. Assessing the impact of procedural security on container port efficiency. Maritime Economics and Logistics. 13(1), 1-28.

Borger, B.D., Bruyne, D.D. 2011. Port Activities, Hinterland Congestion, and Optimal Government Policies: The Role of Vertical Integration in Logistic Operations. Transport Economics and Policy. 45(2), 247-275.

Bos, G., Wiegmans, B. 2016. Short sea shipping: a statistical analysis of influencing factors on SSS in European countries. Shipping and Trade. 3(6), 1-20.

Bottasso, A., Conti, M., Ferrari, C., Merk, O., Tei, A. 2013.The impact of port throughput on local employment: Evidence from a panel of European regions. Transport Policy. 27, 32-38.

Bottasso, A., Conti, M., Ferrari, C., Tei, A.2014. Ports and regional development: A spatial analysis on a panel of European regions. Transport Research Part A. 65, 44-55.

Bottasso, A., Conti, M., Porto, P.C., Ferrari, C., Tei, A. 2018. Port infrastructures and trade: Empirical evidence from Brazil. Transportation Research Part A.107, 126-139.

Braekers, K., Janssens, G.K., Caris, A .2011.Challenges in Managing Empty Container Movements at Multiple Planning Levels. Transport Reviews. 31(6), 681-708.

Brett, V., Roe, M. 2010. The potential for the clustering of the maritime transport sector in the Greater Dublin Region. Maritime Policy \& Management. 37(1), 1-6.

Brooks, M.R., Puckett, S.M., Hensher, D.A., Sammons, A. 2012. Understanding mode choice decisions: A study of Australian freight shippers. Economics and Logistics. 14(3), 274-299.

Brooks, M.R., Schellinck, T. 2015. Measuring port effectiveness: what really determines cargo interests' evaluations of port service delivery? Maritime Policy \& Management. 42(7), 699711. 
Brouer, B. D., Desaulniers, G., Pisinger, D.2014.A matheuristic for the liner shipping network design problem. Transport Research Part E.72, 42-59.

Button, K., Chin, A., Kramberger, T. 2015. Incorporating subjective elements into liners' seaport choice assessments. Transport Policy. 44,125-133.

Caballini, C., Sacone, S., Saeednia, M. 2016. Cooperation among truck carriers in seaport containerized transportation. Transportation Research Part E.93, 38-56.

Caillaux, M.A., Sant'Anna, A.P., Meza, L.A., Soares de Mello, J.C.B.2011.Container logistics in Mercosur: Choice of a transhipment port using the ordinal Copeland method, data envelopment analysis and probabilistic composition. Maritime Economics and Logistics. 13(4), 355-370.

Caldeirinha, V.R., Felício, J. A. 2013. The relationship between 'position-port', 'hardport' and 'soft-port' characteristics and port performance: conceptual models. Maritime Policy \& Management. 40(6), 528-559.

Caldeirinha, V.R., Felício, J. A., Cunha, S .F. 2018. The nexus between port governance and performance. Maritime Policy \& Management. In Press, Corrected Proof.

Cantillo, J., Cantillo, V., Arellana, J. 2018. Modelling with joint choice of ports and countries of origin and destination: application to Colombian ports. Maritime Policy \& Management. 45(6), 720-738.

Cariou, P., Cheaitou, A. 2014. Cascading effects, network configurations and optimal transshipment volumes in liner shipping. Maritime Economics and Logistics 16(3), 321-342.

Cariou, P., Fedi, L., Dagnet, F.2014. The new governance structure of French seaports: an initial post-evaluation. Maritime Policy \& Management. 41(5), 430-443.

Cariou, P., Ferrari, C., Parola, F. 2015.Strategies in maritime and port logistics. Maritime Economics and Logistics. 17(1), 1-8.

Cariou, P., Wolf, F.-C., 2011. Do port state control inspections influence flag- and class-hopping phenomena in shipping?. Journal of Transport Economics and Policy. 45(2), 155-177.

Casaca, A.C.P., Casaca, M. 2017. The impact of muddy bottoms in ports. Maritime Policy \& Management. 44(5), 584-602.

Castillo-Manzano, J.I., Asencio-Flores, J.P. 2012. Competition between New Port Governance Models on the Iberian Peninsula. Transport Reviews. 32(4), 519-537.

Castillo-Manzano, J.I., Fageda, X., Gonzalez-Laxe, F. 2014. An analysis of the determinants of cruise traffic: An empirical application to the Spanish port system. Transport Research Part E. 66,115-125.

Cetin, C.K., Cerit, A. G.2010.Organizational effectiveness at seaports: a systems approach. Maritime Policy \& Management. 37(3), 195-219.

Chang, C., Thai, V. V. 2016. Do port security quality and service quality influence customer satisfaction and loyalty?. Maritime Policy \& Management. 43(6), 720-736.

Chang, C., Wang, C. 2012. Evaluating the effects of green port policy: Case study of Kaohsiung harbor in Taiwan. Transport Research Part D. 17(3), 185-189.

Chang, C.C., Jhang, C. W. 2016. Reducing speed and fuel transfer of the Green Flag Incentive Program in Kaohsiung Port Taiwan. Transportation Research Part D. 46, 1-10

Chang, V., Tovar, B. 2014. Drivers explaining the inefficiency of Peruvian and Chilean ports terminals. Transport Research Part E. 67,190-203.

Chang, V., Tovar, B. 2014. Efficiency and productivity changes for Peruvian and Chilean ports terminals: A parametric distance functions approach. Transport Policy.31, 83-94.

Chang, V., Tovar, B. 2017. Metafrontier analysis on productivity for West Coast of South Pacific terminals. Transportation Research Part A.103, 118-134. 
Chang, Y. 2013. Environmental efficiency of ports: a Data Envelopment Analysis approach. Maritime Policy \& Management. 40(5), 467-478.

Chang, Y. 2014. Economic impact of port sectors on South African economy: An input-output analysis. Transport Policy. 35,333-340.

Chang, Y., Liu, S., Park, H., Roh, Y. 2016.Cruise traveler satisfaction at a port of call. Maritime Policy \& Management. 43(4), 483-494.

Chang, Y., Park, H., Lee, S., Kim, E.2018. Have Emission Control Areas (ECAs) harmed port efficiency in Europe? Transportation Research Part D. Part B.58, 39-53.

Chang, Y., Park, H., Liu, S., Roh, Y. 2016. Economic impact of cruise industry using regional input-output analysis: a case study of Incheon. Maritime Policy \& Management. 43(1), 1-18.

Chang, Y., Song, Y., Roh, Y.2013. Assessing greenhouse gas emissions from port vessel operations at the Port of Incheon. Transport Research Part D. 25, 1-4.

Chang, Y., Tongzon, J., Luo, M., Lee, P.T. 2012. Estimation of Optimal Handling Capacity of a Container Port: An Economic Approach. Transport Reviews. 32(2), 241-258.

Chang, Z., Yang, D., Wan, Y., Han, T. 2018. Analysis on the features of Chinese dry ports: Ownership, customs service, rail service and regional competition. Transport Policy. In Press, Corrected Proof.

Chao, S., Lin, Y. 2011. Evaluating advanced quay cranes in container terminals. Transport Research Part E. 47(4), 432-445.

Chao, S., Yu, H. 2012. Repositioning empty containers in East and North China ports. Economics and Logistics. 14(4), 435-454.

Chatzinikolaou, S.D., Oikonomou, S.D., Ventikos, N. P. 2015.Health externalities of ship air pollution at port - Piraeus port case study. Transportation Research Part D. 40, 155-165.

Chhetri, P., Nkhoma, M., Peszynski, K., Chhetri, A., Lee, P.T. 2018. Global logistics city concept: a cluster-led strategy under the belt and road initiative. Maritime Policy \& Management. 45(3), 319-335.

Cheaitou, A., Cariou, P.2012.Liner shipping service optimisation with reefer containers capacity: an application to northern Europe-South America trade. Maritime Policy \& Management. 39(6), 589-602.

Chen, C., Lam, J.S.L. 2018. Sustainability and interactivity between cities and ports: a two-stage data envelopment analysis (DEA) approach. Maritime Policy \& Management. In Press, Corrected Proof.

Chen, D., Yang, Z. 2017. Investment in container ports along the Maritime Silk Road in the context of international industry transfer: the case of the port of Colombo. Maritime Economics and Logistics. 1-17.

Chen, D., Yang, Z., 2018. Systematic optimization of port clusters along the Maritime Silk Road in the context of industry transfer and production capacity constraints. Transportation Research Part E .109, 174-189.

Chen, H., Cullinane, K., Liu, N. 2017. Developing a model for measuring the resilience of a porthinterland container transportation network. Transportation Research Part E.97,282-301

Chen, H., Lam, J. S.L., Liu, N. 2018.Strategic investment in enhancing port-hinterland container transportation network resilience: A network game theory approach. Transportation Research Part B.111, 83-112.

Chen, H., Liu, S. 2015.Optimal concession contracts for landlord port authorities to maximize traffic volumes. Maritime Policy \& Management. 42(1), 11-25. 
Chen, H., Liu, S. 2016.Should ports expand their facilities under congestion and uncertainty? Transportation Research Part B.85, 109-131.

Chen, J.M., Lijesen, M.G., Nijkamp, P. 2017. Interpretation of cruise industry in a two-sided market context: An exploration on Japan. Maritime Policy \& Management. 44(6), 790-801.

Chen, M., Chang, K., Hsu, C., Leon, G.A.V. 2017. Investigating the impacts of guanxi and relationship marketing in port logistics: two cases. Maritime Economics and Logistics.1-21.

Chen, S. 2009. Port administrative structure change worldwide: Its implication for restructuring port authorities in Taiwan. Transport Reviews. 29(2), 163-181.

Chen, S., Everett, S. 2014. The dynamics of port reform: different contexts, similar strategies. Maritime Policy \& Management. 41(3), 288-301.

Chen, G., Yang, Z. 2010.Optimizing time windows for managing export container arrivals at Chinese container terminals. Maritime Economics and Logistics. 12(1), 111-126.

Chen, X., Zhou, X., List, G .F. 2011. Using time-varying tolls to optimize truck arrivals at ports. Transport Research Part E. 47(6), 965-982.

Chen, Z., Pak, M. 2017. A Delphi analysis on green performance evaluation indices for ports in China. Maritime Policy \& Management. 44(5), 537-550.

Cheng, J., Yang, Z. 2017. The equilibria of port investment in a multi-port region in China. Transportation Research Part E.108, 36-51.

Chengpeng, W., Di, Z., Xinping, Y., Zaili, Y. 2018. A novel model for the quantitative evaluation of green port development - A case study of major ports in China. Transportation Research Part D.61, 431-443.

Cheon, S., Dowall, D.E., Song, D. 2010. Evaluating impacts of institutional reforms on port efficiency changes: Ownership, corporate structure, and total factor productivity changes of world container ports. Transportation Research Part E. 46(4), 546-561.

Cheon, S., Maltz, A., Dooley, K. 2017. The link between economic and environmental performance of the top 10 U.S. ports. Maritime Policy \& Management. 44(2), 227-247.

Cheon, S., Song, D., Park, S. 2017. Does more competition result in better port performance? Maritime Economics and Logistics. 20(3), 433-455.

Cheong, I., Cho, J. 2013. The impact of Korea's FTA network on seaborne logistics. Maritime Policy \& Management. 40(2), 146-160.

Chin, A.T.H., Low, J. M.W. 2010. Port performance in Asia: Does production efficiency imply environmental efficiency? Transportation Research Part D. 15(8), 483-488.

Choi, H., Moon, Y. S., Kim, J.J., Lee, J.K., Lee, K.B., Shin, J.J. 2018. Development of an IoTbased container tracking system for China's Belt and Road (B\&R) initiative. Maritime Policy \& Management. 45(3), 388-402.

Choi, K., Lim, S. 2018. Tariff protection and port privatization: An import-competing approach. Maritime Economics and Logistics. 20(2), 228-252.

Cigolini, R., Pero, M., Rossi, T., Sianesi, A. 2013.Using simulation to optimize transhipment systems: Applications in field. Maritime Economics and Logistics. 15(3), 332-348.

Cimpeanu, R., Devine, M.T., O'Brien, C. 2017. A simulation model for the management and expansion of extended port terminal operations. Transportation Research Part E. 98, 105-131.

Clark, D.J., Jorgensen, F., Pedersen, P.A. 2009. Strategic interactions between transport operators with several goals. Journal of Transport Economics and Policy. 43(3), 385-403.

Clintworth, M., Boulougouris, E., Lee, B.S. 2018. Combining multicriteria decision analysis and cost- benefit analysis in the assessment of maritime projects financed by the European Investment Bank. Maritime Economics and Logistics, 20(1), 29-47. 
Coto-Millán, P., Casares-Hontañón, P., Castanedo, J., Inglada, V., Mateo-Mantecón, I., Pesquera, M.Á. Sainz-González, R. 2013. Demand for port traffic by type of good in Spain: 1995.I2007.IV. Maritime Economics and Logistics. 15(4), 444-466.

Coto-Millán, P., Casares - Hontañón, P., González, R. S., Mantecón, I.M., Agüeros, M., Badiola, A., Castanedo, J., Pesquera, M.Á. 2016. Regulation, competition, crisis and technical efficiency of companies operating in Spanish ports (2002-2011). Maritme Economics and Logistics. 18(3), 282-294.

Coto-Millán, P., Fernández, X.L., Hidalgo, S., Pesquera, M.Á. 2016.Public regulation and technical efficiency in the Spanish Port Authorities: 1986-2012. Transport Policy. 47, 139-148.

Cruz, M.R.P.D., Ferreira, J.O J., Azevedo, S .G. 2012. A Strategic Diagnostic Tool Applied to Iberian Seaports: An Evolutionary Perspective. Transport Reviews. 32(3), 333-349.

Cruz, M.R.P., Ferreira, J.J., Azevedo, S.G. 2013. Key factors of seaport competitiveness based on the stakeholder perspective: An Analytic Hierarchy Process (AHP) model. Maritime Economics and Logistics. 15(4), 416-443.

Cruz, R. P.D., Ferreira, J.J.M., Azevedo, S.G. 2013. Logistics resources in seaport performance: multicriteria analysis. Maritime Policy \& Management. 40(6), 588-613.

Cruz, C.O., Marques, R .C.2012.Risk-Sharing in Seaport Terminal Concessions. Transport Reviews. 32(4), 455-471.

Cui, H., Notteboom, T. 2017. Modelling emission control taxes in port areas and port privatization levels in port competition and co-operation subgames. Transportation Research Part D. 56,110128.

Cui, Q. 2017. Environmental efficiency measures for ports: an application of RAM-Tobit-RAM with undesirable outputs. Maritime Policy \& Management. 44(5), 551-564.

Cullinane, K., Bergqvist, R., Wilmsmeier, G. 2012.The dry port concept - Theory and practice. Economics and Logistics. 14(1), 1-13.

Cullinane, K., Notteboom, T., Sanchez, R., Wilmsmeier, G. 2012.Costs, revenue, service attributes and competition in shipping. Economics and Logistics. 14(3), 265-273.

Cullinane, K., Wang, Y.2012.The hierarchical configuration of the container port industry: an application of multiple linkage analysis. Maritime Policy \& Management. 39(2), 169-187.

Dang, Q., Nielsen, I.E., Yun, W. 2013 Replenishment policies for empty containers in an inland multi-depot system. Maritime Economics and Logistics. 15(1), 120-149.

Danielis, R., Gregori, T. 2013. An input-output-based methodology to estimate the economic role of a port: The case of the port system of the Friuli Venezia Giulia Region, Italy. Maritime Economics and Logistics. 15(2), 222-255.

Davarzan, H., Fahimnia, B., Bell, M., Sarkis, J. 2016. Greening ports and maritime logistics: A review. Transportation Research Part D. 48, 473-487.

Defilippi, E. 2012. Good regulations, bad regulation: a Peruvian port case. Maritime Policy \& Management. 39(6), 641-651.

Dekker, S., Verhaeghe, R., Wiegmans, B. 2011. Economically-efficient port expansion strategies: An optimal control approach. Transport Research Part E. 47(2), 204-215.

Deng, P., Lu, S., Xiao, H. 2013. Evaluation of the relevance measure between ports and regional economy using structural equation modeling. Transport Policy. 27, 123-133.

Deng,X., Wang, Y., Yeo, G. 2017. Enterprise Perspective-based Evaluation of Free Trade Port Areas in China. Maritime Economics and Logistics. 19(3), 451-473. 
Díaz-Hernández, J.J., Martínez - Budría, E., Salazar-González, J. J.2014. Measuring cost efficiency in the presence of quasi-fixed inputs using dynamic Data Envelopment Analysis: The case of port infrastructure. Maritime Economics and Logistics 16(2), 111-126.

Ding, D., Teo, C. 2010. World container port throughput follows lognormal distribution. Maritime Policy \& Management. 37(4), 401-426.

Diz, G.S.S., Oliveira, F., Hamacher, S. 2017. Improving maritime inventory routing: application to a Brazilian petroleum case. Maritime Policy \& Management. 44(1), 42-61.

Do, N., Nam, K., Le, Q. N. 2011. A consideration for developing a dry port system in Indochina area. Maritime Policy \& Management. 38(1), 1-9.

Dong, G., Huang, R., Ng, P. 2016. Tacit collusion between two terminals of a port. Transportation Research Part E. 93, 199-211.

Donselaar, P.W., Kolkman, J. 2010. Societal costs and benefits of cooperation between port authorities. Maritime Policy \& Management. 37(3), 271-284.

Dooms, M., Haezendonck, E., Verbeke, A. 2015.Towards a meta-analysis and toolkit for port related socio-economic impacts: a review of socioeconomic impact studies conducted for seaports. Maritime Policy \& Management. 42(5), 1-22.

Dragović, B. Škurić, M., Kofjač, D. 2014. A proposed simulation-based operational policy for cruise ships in the port of Kotor. Maritime Policy \& Management. 41(6), 560-588.

Dragovic, B., Tzannatos, E., Tselentis, V., Meštrovic', R., Škuric',M. 2018.Ship emissions and their externalities in cruise ports. Transportation Research Part D.61, 289-300.

Du, Y., Chen, Q., Quan, X., Long, L., Fung, R.Y.K. 2011.Berth allocation considering fuel consumption and vessel emissions. Transport Research Part E. 47(6), 1021-1037.

Du, Y., Meng, Q., Wang, S. 2017. Mathematically calculating the transit time of cargo through a liner shipping network with various trans-shipment policies. Maritime Policy \& Management. 44(2), 248-270.

Ducruet, C. 2016. The polarization of global container flows by interoceanic canals: geographic coverage and network vulnerability. Maritime Policy \& Management. 43(8), 976-991.

Ducruet, C., Cuyala, S., Hosni, A.E. 2016. The changing influence of city-systems on global shipping networks: an empirical analysis. Shipping and Trade. Shipping and Trade. 1(4), 1-19.

Ducruet, C., Lee, S., Ng, A. K.Y.2010. Centrality and vulnerability in liner shipping networks: revisiting the Northeast Asian port hierarchy. Maritime Policy \& Management. 37(1), 17-36.

Ducruet, C., Zaidi, F. 2012. Maritime constellations: a complex network approach to shipping and ports. Maritime Policy \& Management. 39(2), 159-168.

Enshaei, H., Mesbahi, E. 2011. Development of a methodology for estimation of ballast water operation in UK ports. Maritime Policy \& Management. 38(7), 691- 703.

Ensslin, L., Dezem, V., Dutra, A., Ensslin, S.R., Somensi, K. 2017. Seaport-performance tools: an analysis of the international literature. Maritime Economics and Logistics. 1-16

Erol, S. 2017. Calculation of the freight revenues in Turkey-focused maritime transportation. Maritime Policy \& Management. 44(7), 815-824.

Escamilla-Navarro, L., García-Menéndez, L., Pérez-García, E., 2010. Integration of foreign trade and maritime transport statistics in Spain. Maritime Policy \& Management. 37(4), 347-375.

Esparza, A., Cerbán, M.M., Piniella, F.2016.State-owned Spanish Port System oversizing: an analysis of maximum operational capacity. Maritime Policy \& Management. 44(8), 995-1011.

Esteve-Perez, J., Garcia-Sanchez, A. 2015. Cruise market: Stakeholders and the role of ports and tourist hinterlands. Maritime Economics and Logistics 17(3), 371-388. 
Esteve-Perez, J., Garcia-Sanchez, A. 2017. Characteristics and consequences of the cruise traffic seasonality on ports: the Spanish Mediterranean case. Maritime Policy \& Management. 44(3), 358-372.

Fabling, R., Grimes, A., Sanderson, L .2013. Any port in a storm: Impacts of new port infrastructure on exporter behavior. Transport Research Part E. 49(1), 33-86.

Fageda, X., Gonzalez-Aregal, M. 2017. Do all transport modes impact on industrial employment? Empirical evidence from the Spanish regions. Transport Policy. 55, 70-78.

Fan, L., Wilson, W.W., Dahl, B. 2012. Congestion, port expansion and spatial competition for US container imports. Transport Research Part E. 48(6), 1121-1136.

Fan, L., Wilson, W.W., Dahl, B. 2012. Impacts of new routes and ports on spatial competition for containerized imports into the United States. Maritime Policy \& Management. 39(5), 479-501.

Fan, L., Wilson, W.W., Tolliver, D. 2009. Logistical rivalries and port competition for container flows to US markets: Impacts of changes in Canada's logistics system and expansion of the Panama Canal. Maritime Economics and Logistics. 11(4), 327-357.

Fan, L., Wilson, W.W., Tolliver, D .2010. Optimal network flows for containerized imports to the United States. Transportation Research Part E. 46(5), 735-749.

Fan, L Wilson, W.W. 2012. Impacts of Congestion and Stochastic Variables on the Network for US Container Imports. Transport Economics and Policy. 46(3), 381-398.

Fancello, G., Pani, C., Pisano, M., Serra, P., Zuddas, P., Fadda, P. 2011. Prediction of arrival times and human resources allocation for container terminal. Maritime Economics and Logistics. 13(2), 142-173.

Farhan, J., Ong, G.P. 2018. Forecasting seasonal container throughput at international ports using SARIMA models. Maritime Economics and Logistics, 20(1), 131-148.

Farrell, S. 2012.The ownership and management structure of container terminal concessions. Maritime Policy \& Management. 39(1), 7-26.

Farrell, S., Vanelslander, T. 2015. Comparison of Public -Private Partnerships in Airports and Seaports in Low- and Middle-Income Countries. Transport Reviews. 35(3), 329-351.

Felício, J. A., Caldeirinha, V., Dionísio, A. 2015.The effect of port and container terminal characteristics on terminal performance. Maritime Economics and Logistics. 17(4), 493-514.

Feo-Valero, M., García-Menéndez, L., Sáez-Carramolino, L. 2011.The importance of the inland leg of containerized maritime shipments: An analysis of modal choice determinants in Spain. Transport Research Part E. 47(4), 446-460.

Ferrari, C., Basta, M. 2009. Port concession fees based on the price-cap regulation: A DEA approach. Maritime Economics and Logistics. 11(1), 121- 135.

Ferrari, C., Musso, E. 2011. Italian ports: towards a new governance? Maritime Policy \& Management. 38(3), 335-346.

Ferrari, C., Parola, F., Gattorna, E. 2011. Measuring the quality of port hinterland accessibility: The Ligurian case. Transport Policy. 18(2), 382-391.

Ferrari, C., Parola, F., Tei, A. 2015.Governance models and port concessions in Europe: Commonalities, critical issues and policy perspectives. Transport Policy. 41, 60-67.

Ferrari, C., Puliafito, P. P., Tei, A. 2017. Dynamics in terminal concessions: the role of performances. Maritime Economics and Logistics. 1-12.

Flitsch, V., Herz, N., Wolff, J., Baird, A.J.2014.Maritime policy in the North Sea region: Application of the cluster approach. Maritime Economics and Logistics 16(4), 484-500. 
Franc, P., Sutto, L. 2014. Impact analysis on shipping lines and European ports of a cap- and-trade system on CO2 emissions in maritime transport. Maritime Policy \& Management. 41(1), 6178.

Francesco, M.D., Crainic, T.G., Zuddas, P. 2009. The effect of multi-scenario policies on empty container repositioning. Transportation Research Part E. 45(5), 758-770.

Francesco, M. D., Fancello, G., Serra, P., Zuddas, P. 2015. Optimal management of human resources in transhipment container ports. Maritime Policy \& Management. 42(5), 436-458.

$\mathrm{Fu}$, Q., Liu, L., Xu, Z. 2010. Port resources rationalization for better container barge services in Hong Kong. Maritime Policy \& Management. 37(6), 543-561.

Fung, M.K. 2009. Does trigger point mechanism create monopoly power for Hong Kong container terminals? Maritime Policy \& Management. 36(4), 325-336.

Garcia-Alonso, L., Monios, J., Vallejo -Pinto, J.A. 2017. Port competition through hinterland accessibility: the case of Spain. Maritime Economics and Logistics. 1-20.

Garcia-Alonso, L., Sanchez-Soriano, J. 2010. Analysis of the Evolution of the Inland Traffic Distribution and Provincial Hinterland Share of the Spanish Port System. Transport Reviews. 30(3), 275- 297.

Garcia-Alonso, L., Sanchez-Soriano, J. 2009. Port selection from a hinterland perspective. Maritime Economics and Logistics. 11(3), 260-269.

Gaur, P., Pundir, S., Sharma, T. 2011.Ports face inadequate capacity, efficiency and competitiveness in a developing country: case of India. Maritime Policy \& Management. 38(3), 293-314.

Geerlings, H., Heij, R., Duin, R. 2018. Opportunities for peak shaving the energy demand of shipto-shore quay cranes at container terminals. 3(3).

Gekara, V.O., Chhetri, P. 2013. Upstream transport corridor inefficiencies and the implications for port performance: a case analysis of Mombasa Port and the Northern Corridor. Policy \& Management. 40(6), 559-573.

Gharehgozli, A.H., Mileski, J.P., Duru, O. 2017. Heuristic estimation of container stacking and reshuffling operations under the containership delay factor and mega-ship challenge. Maritime Policy \& Management. 44(3), 373-391.

Gharehgozli, A.H., Roy, D., Koster, R. 2016. Sea container terminals: New technologies and OR models. Maritme Economics and Logistics. 18(2), 103-140.

Glen, D., Marlow, P. 2009. Maritime Statistics: a new forum for practitioners. Maritime Policy \& Management. 36(2), 185-195.

Gocer, A., Vura, C. A., Devec, D.A. 2017. Drivers of and barriers against market orientation: a study of Turkish container ports. Maritime Economics and Logistics.1-28.

Golias, M.M., Saharidis, G.K., Boile, M., Theofanis, S., Ierapetritou, M.G. 2009. The berth allocation problem: Optimizing vessel arrival time. Maritime Economics and Logistics. 11(4), 358-377.

Golias, M.M., Haralambides, H.E. 2011. Berth scheduling with variable cost functions. Maritime Economics and Logistics. 13(2), 174-189.

Gonzalez, M.M., Trujill, L. 2009. Efficiency measurement in the port industry: A survey of the empirical evidence. Transport Economics and Policy. 43(2), 257-277.

Gou, X., Lam, J.S.L. 2018. Risk analysis of marine cargoes and major port disruptions. Maritime Economics and Logistics, 1-27.

Grainger, A., 2014.Trade and customs compliance costs at ports. Maritime Economics and Logistics. 16(4), 467-483. 
Grida, M., Lee, C. 2018. An empirical model for estimating berth and sailing times of mega container ships. Maritime Policy \& Management. In Press, Corrected Proof.

Guan, Y. 2010. Analysis of berth allocation and inspection operations in a container terminal. Maritime Economics and Logistics. 12(4), 347-369.

Guan, C., Liu, R. 2009. Container terminal gate appointment system optimization. Maritime Economics and Logistics. 11(4), 378.

Gui, L., Russo, A.P. 2011. Cruise ports: a strategic nexus between regions and global linesevidence from the Mediterranean. Maritime Policy \& Management. 38(2), 129- 150.

Gumede, S., Chasomeris, M. 2018. Pricing strategy and tariff structure for a port authority: a case study of South Africa. Maritime Policy \& Management. 45(6), 756-769.

Guner, S. 2017. Incorporating value judgments into port efficiency measurement models: insights from Turkish ports. Maritime Economics and Logistics.1-18.

Guo, L., Yang, D., Yang, Z. 2018. Port integration method in multi-port regions (MPRs) based on the maximal social welfare of the external transport system. Transportation Research Part A.110, 243-257.

Guo, L., Yang, Z. 2018. Evaluation of foreign trade transport accessibility for Mainland China. Maritime Policy \& Management. 45(1), 34-52.

Gurning, S., Cahoon, S. 2011. Analysis of multi-mitigation scenarios on maritime disruptions. Maritime Policy \& Management. 38(3), 251-268.

Gutiérrez, E., Lozano, S., Adenso-Díaz, B., González-Torre, P.2015. Efficiency assessment of container operations of shipping agents in Spanish ports. Maritime Policy \& Management. 42(6), 591-607.

Güner, S. 2015. Investigating infrastructure, superstructure, operating and financial efficiency in the management of Turkish seaports using data envelopment analysis. Transport Policy. 40, 3648.

Güven, C., Eliiyi, D.T. 2018. Modelling and optimisation of online container stacking with operational constraints. Maritime Policy \& Management. In Press, Corrected Proof.

Ha, M., Yang, Z. 2017. Comparative analysis of port performance indicators: Independency and interdependency. Transportation Research Part A.103, 264-278.

Ha, M., Yang, Z., Notteboom, T., Ng, A.K.Y., Heo, M. 2017. Revisiting port performance measurement: A hybrid multistakeholder framework for the modelling of port performance indicators. Transportation Research Part E.103, 1-16.

Hadjiconstantinou, E., Ma, N.L 2010. Evaluating straddle carrier deployment policies: a simulation study for the Piraeus container terminal. Maritime Policy \& Management. 36(4), 353- 366.

Haezendonck, E., Dooms, M., Verbeke, A .2014. A new governance perspective on porthinterland relationships: The Port Hinterland Impact (PHI) matrix. Maritime Economics and Logistics 16(3), 229-249.

Haezendonck, E., Langenus, M. 2018. Integrated ports clusters and competitive advantage in an extended resource pool for the Antwerp Seaport. Maritime Policy \& Management. In Press, Corrected Proof.

Halim, R. A., Kwakkel, J.H., Tavasszy, L. A.2016. A strategic model of port-hinterland freight distribution networks. Transportation Research Part E. 95, 368-384.

Hall, P.V., Jacobs, W. 2012. Why are maritime ports (still) urban, and why should policy-makers care? Maritime Policy \& Management. 39(2), 189-206. 
Hameri, A., Borg, A., Eloranta, E.2014.Vendor-managed inventory in a global maritime supply chain - The case of a Brazilian pulp producer. Maritime Economics and Logistics 16(2), 207227.

Han, W., Chen, H., Liu, S. 2018. Optimal concession contracts for landlord port authorities with different pursuing goals. Maritime Policy \& Management. In Press, Corrected Proof.

Haralambides, H. 2017. Globalization, public sector reform, and the role of ports in international supply chains. Maritime Economics and Logistics. 19(1), 1-51.

Haralambides, H., Acciaro, M. 2015. The new European port policy proposals: Too much ado about nothing? Maritime Economics and Logistics. 17(2), 127-141.

Haralambides, H., Gujar, G. 2012. On balancing supply chain efficiency and environmental impacts: An eco-DEA model applied to the dry port sector of India. Economics and Logistics. 14(1), 122-137.

Haralambides, H., Veldman, S., Drunen, E., Liu, M. 2011. Determinants of a regional port-centric logistics hub: The case of East Africa. Maritime Economics and Logistics. 13(1), 78-97.

Harrington, J., Murphy, J., Coleman, M., Jordan, D., Szacsuri, G. 2016. Financial modelling and analysis of the management of dredged marine sediments - development of a decision support tool. Shipping and Trade. 1(7), 1-10.

Hartman, B.C., Clott, C.B. 2012. An economic model for sustainable harbor trucking. Transport Research Part D. 17(5), 354-360.

Hartmann, S. 2013.Scheduling reefer mechanics at container terminals. Transport Research Part E. 51, 17-27.

Hasheminia, H., Jiang, C. 2017. Strategic trade-off between vessel delay and schedule recovery: an empirical analysis of container liner shipping. Maritime Policy \& Management. 44(4), 458473.

Heilig, L., Lalla-Ruiz, E., Voß, S. 2017. Multi-objective inter-terminal truck routing. Transportation Research Part E. 106, 178-202.

Hoffmann, J., Wilmsmeier, G., Lun, Y.H.V. 2017. Connecting the world through global shipping networks. Shipping and Trade. 2:7.

Holguín-Veras, J., Jaller, M. Wachtendorf, T. 2012. Comparative performance of alternative humanitarian logistic structures after the Port-au-Prince earthquake: ACEs, PIEs, and CANs. Transport Research Part A. 46(10), 1623- 1640.

Hollen, R. M.A., Bosch, F.A.J., Volberda, H.W. 2015. Strategic levers of port authorities for industrial ecosystem development. Maritime Economics and Logistics. 17(1), 79-96.

Homsombat, W., Yip, T .L. Yang, H., Fu, X. 2013. Regional cooperation and management of port pollution. Maritime Policy \& Management. 40(5), 451-466.

Horst, M. R., Lugt, L.M. 2012. Coordination mechanisms in improving hinterland accessibility: empirical analysis in the port of Rotterdam. Maritime Policy \& Management. 38(4), 415-435.

Horst, M.R.V.D., Lugt, L. M.V.D.2014. An Institutional Analysis of Coordination in Liberalized Port-related Railway Chains: An Application to the Port of Rotterdam. Transport Reviews. 34(1), 68-85.

Hsieh, C., Tai, H., Lee, Y. 2014. Port vulnerability assessment from the perspective of critical infrastructure interdependency. Maritime Policy \& Management. 41(6), 589-606.

Huang, S.Y., Hsu, W.J., He, Y. 2011. Assessing capacity and improving utilization of anchorages. Transport Research Part E. 47(2), 216-227.

Huang, Y., Rashidi, T. H., Gardner, L. 2016. Modelling the global maritime container network. Maritme Economics and Logistics. 20(3), 400-420. 
Hui-Huang, T. 2015.A comparative study on pollutant emissions and hub-port selection in Panama Canal expansion. Maritime Economics and Logistics. 17(2), 163-178.

Iannone, F. 2012. A model optimizing the port-hinterland logistics of containers: The case of the Campania region in Southern Italy. Economics and Logistics. 14(1), 33-72.

Iannone, F. 2012. The private and social cost efficiency of port hinterland container distribution through a regional logistics system. Transport Research Part A. 46(9), 1424- 1448.

Imai, A., Nishimura, E., Papadimitriou, S. 2013.Marine container terminal configurations for efficient handling of mega-containerships. Transport Research Part E. 49(1), 141-158.

Innes, A., Monios, J. 2018. Identifying the unique challenges of installing cold ironing at small and medium ports - The case of Aberdeen. Transportation Research Part D.62, 298-313.

Irannezhad, E., Prato, C., Hickman, M. 2017. A joint hybrid model of the choices of container terminals and of dwell time. Transportation Research Part E. In Press Corrected Proof.

Iris, Ç., Christensen, J., Pacino, D., Ropke, S. 2018. Flexible ship loading problem with transfer vehicle assignment and scheduling. Transportation Research Part B.111, 113-134.

Ishii, M., Lee, P.T., Tezuka, K., Chang, Y. 2013. A game theoretical analysis of port competition. Transport Research Part E. 49(1), 92-106.

Jafari, M., Taghavifard, M. T., Rouhani, S., Moalagh, M. 2010. E-commerce development experiences in world's leading container ports and offering a model for Shahid Rajaee Port. Maritime Policy \& Management. 37(1), 53-72.

Jansen, M., Tulder, R., Afrianto, R. 2018. Exploring the conditions for inclusive port development: the case of Indonesia. Maritime Policy \& Management. In Press, Corrected Proof.

Jeevan, J., Chen, S., Cahoon, S. 2017. Determining the influential factors of dry port operations: worldwide experiences and empirical evidence from Malaysia. Maritime Economics and Logistics. 20(3), 476-494.

Jia, H., Lampe, O.D., Solteszova, V., Strandenes, S. P. 2017. Norwegian port connectivity and its policy implications. Maritime Policy \& Management. 44(8), 956-966.

Jiang, C., Lu, L., Lu, J.J. 2017. Socioeconomic factors affecting the job satisfaction levels of selfemployed container truck drivers: a case study from Shanghai Port. Maritime Policy \& Management. 44(5), 641-656.

Jiang, C., Wan, Y., Zhang, A. 2017. Internalization of port congestion: strategic effect behind shipping line delays and implications for terminal charges and investment. Maritime Policy \& Management. 44(1), 112-130.

Jiang, J., Lee, L.H., Chew, E.P., Gan, C.C. 2015. Port connectivity study: An analysis framework from a global container liner shipping network perspective. Transportation Research Part E. 73, 47-64.

Jiang, X.J., Jin, J. G. 2017. A branch-and-price method for integrated yard crane deployment and container allocation in transshipment yards. Transportation Research Part B.98, 62-75.

Jin, J.G., Lee, D., Hu, H. 2015. Tactical berth and yard template design at container transshipment terminals: A column generation based approach. Transportation Research Part E.73, 168-184.

Johnson, H., Styhre, L. 2015. Increased energy efficiency in short sea shipping through decreased time in port. Transportation Research Part A. 71, 167-178.

Jonkeren, O., Rietveld, P. 2016. Protection of Critical Waterborne Transport Infrastructures: An Economic Review. Transport Reviews. 36(4), 437-453.

Jordan, L., 2013.A critical assessment of Trinidad and Tobago as a cruise homeport: doorway to the South American cruise market? Maritime Policy \& Management. 40(4), 367-383. 
Ju, S., Liu, N.2015. Efficiency and its influencing factors in port enterprises: empirical evidence from Chinese portlisted companies. Maritime Policy \& Management. 42(6), 571-590.

Jula, P., Leachman, R.C. 2011. A supply-chain optimization model of the allocation of containerized imports from Asia to the United States. Transport Research Part E. 47(5), 609622.

Jula, P., Leachman, R.C. 2011.Long- and Short-Run supply-chain optimization models for the allocation and congestion management of containerized imports from Asia to the United States. Transport Research Part E. 47(5), 593-608.

Justice, V., Bhaskar, P., Pateman, H., Cain, P., Cahoon, S. 2016. US container port resilience in a complex and dynamic world. Maritime Policy \& Management. 43(2), 179-191.

Kadaifci, C., Asan, U., Serdarasan, S., Arican, U. 2018. A new rule-based integrated decision making approach to container transshipment terminal selection. Maritime Policy \& Management. In Press, Corrected Proof.

Kaiser, I.M., Bezerra, B.S., Castro, L.I.S. 2013. Is the environmental policies procedures a barrier to development of inland navigation and port management? A case of study in Brazil. Transport Research Part A. 47, 78-86.

Kang, C., Dongxu, C., Xueshan, S., Zhongzhen, Y. 2016. Container Ocean-transportation System Design with the factors of demand fluctuation and choice inertia of shippers. Transportation Research Part E.95, 267-281.

Kang, D., Woo, S. 2017. Liner shipping networks, port characteristics and the impact on port performance. Maritime Economics and Logistics. 19(2) 274-295.

Karsten, C.V., Brouer, B.D., Desaulniers, G., Pisinger, D. 2017. Time constrained liner shipping network design. Transportation Research Part E. 105, 152-162.

Kaselimi, E.N., Notteboom, T.E., Borger, B. D. 2011. A game theoretical approach to competition between multi-user terminals: the impact of dedicated terminals. Maritime Policy \& Management. 38(4), 395-414.

Kashiha, M., Thill, J., Depken II, C .A. 2016. Shipping route choice across geographies: Coastal vs. landlocked countries. Transportation Research Part E. 91, 1-14.

Kavirathna, C., Kawasaki, T., Hanaoka, S., Matsuda, T. 2018. Transshipment hub port selection criteria by shipping lines: the case of hub ports around the bay of Bengal. Shipping and Trade, $3(4)$.

Kaysi, I., Nehme, N. 2016. Optimal investment strategy in a container terminal: A game theoretic approach. Maritme Economics and Logistics. 18(3), 250-263.

Keceli, Y. 2011. A proposed innovation strategy for Turkish port administration policy via information technology. Maritime Policy \& Management. 38(2), 151-167.

Keceli, Y. 2016. A simulation model for gate operations in multipurpose cargo terminals. Maritime Policy \& Management. 43(8), 945-958.

Kenyon, G. N., Goldsmith, M., Neureuther, B.D., Zhou, D. 2017. Improving the return on investment in ports: opportunities in data management. Maritime Economics and Logistics.117.

Khadaroo, J., Seetanah, B. 2009. The role of transport infrastructure in FDI: Evidence from Africa using GMM Estimates. Transport Economics and Policy. 43(3):365-384.

Khalid, N., Suppiah, R. 2010. The Rotterdam Rules: Catalyst for trade or cumbersome convention? Maritime Policy \& Management. 36(4), 447- 450.

Kim, H., Lam, J. S.L., Lee, P. T. 2018. Analysis of liner shipping networks and transshipment flows of potential hub ports in sub-Saharan Africa. Transport Policy. 69, 193-206. 
Kim, J. 2014. Port user typology and representations of port choice behavior: A Q-methodological study. Maritime Economics and Logistics 16(2), 165-187.

Klerides, E., Hadjiconstantinou, E. 2011. Modelling and solution approaches to the multi-load AGV dispatching problem in container terminals. Maritime Economics and Logistics. 13(4), 371-386.

Klopott, M. 2013. Restructuring of environmental management in Baltic ports: case of Poland. Maritime Policy \& Management. 40(5), 439-450.

Koetse, M. J., Rietveld, P. 2012. Adaptation to climate change in the transport sector. Transport Reviews. 32(3), 267-286.

Kontovas, C., Psaraftis, H.N. 2011.Reduction of emissions along the maritime intermodal container chain: operational models and policies. Maritime Policy \& Management. 38(4), 451469.

Kosowska-Stamirowska, Z., Ducruet, C., Rai, N. 2017. Evolving structure of the maritime trade network: evidence from the Lloyd's Shipping Index (1890-2000).Shipping and Trade. 1(10), $1-17$.

Knapp, S., Franses, P.H. 2010. Comprehensive Review of the Maritime Safety Regimes: Present Status and Recommendations for Improvements. Transport Reviews. 30(2), 241-270.

Knapp, S., Velden, M. 2009. Visualization of Differences in Treatment of Safety Inspections across Port State Control Regimes: A Case for Increased Harmonization Efforts. Transport Reviews. 29(4), 499-514.

Lacoste, R., Douet, M. 2013. The adaptation of the landlord port model to France's major seaports: a critical analysis of local solutions. Policy \& Management. 40(1), 27-47.

Lai, C., Chiu, R., Chang, C., Ye, K. 2014. Organizational change for port authorities: a social information processing analysis. Maritime Policy \& Management. 41(4), 405-424.

Laih, C., Sun, P. 2013.Effects of the optimal n-step toll scheme on bulk carriers queuing for multiple berths at a busy port. Transport Policy. 28, 42-50.

Lam, J.S.L. 2015. Disruption risks and mitigation strategies: an analysis of Asian ports. Maritime Policy \& Management. 42(5), 415-435.

Lam, J.S.L., Cullinane , K.P.B., Lee, P.T. 2018. The 21st-century Maritime Silk Road: challenges and opportunities for transport management and practice. Transport Reviews. 38(4), 413-415.

Lam, J.S.L., Lassa, J.A. 2017. Risk assessment framework for exposure of cargo and ports to natural hazards and climate extremes. Maritime Policy \& Management. 44(1), 1-15.

Lam, J.S.L., Notteboom, T. 2014.The Greening of Ports: A Comparison of Port Management Tools Used by Leading Ports in Asia and Europe. Transport Reviews. 34(2), 169-189.

Lam, J.S.L., Voorde, E. 2011. Scenario analysis for supply chain integration in container shipping. Maritime Policy \& Management. 38(7), 705- 725.

Lam, J.S.L., Yap, W. Y. 2011. Container port competition and complementarity in supply chain systems: Evidence from the Pearl River Delta. Maritime Economics and Logistics. 13(2), 102120.

Langen, P.W.D., Berg, R.V.D., Willeumier, A.2012. A new approach to granting terminal concessions: the case of the Rotterdam World Gateway terminal. Maritime Policy \& Management. 39(1), 79-90.

Langen, P.W.D., Heij, C. 2014.Corporatisation and Performance: A Literature Review and an Analysis of the Performance Effects of the Corporatisation of Port of Rotterdam Authority. Transport Reviews. 34(3), 396-414. 
Langen, P.W.D., Udenio, M., Fransoo, J. C., Helminen, R. 2016. Port connectivity indices: an application to European RoRo shipping. Shipping and Trade. 1(6), 1-19.

Lau, Y., Ducruet, C., Ng, A.K. Y., Fu, X. 2017. Across the waves: a bibliometric analysis of container shipping research since the 1960s. Maritime Policy \& Management. 44(6), 667-684.

Lau, Y., Ng, A.K. Y., Fu, X., Li, K.X. 2013. Evolution and research trends of container shipping. Maritime Policy \& Management. 40(7), 654-674.

Lau, Y., Tam, K., Ng, A.K. Y., Fu, X., Jing, Z., Feng, J. 2018. Effects of the 'Belt and Road' initiative on the wine import logistics of China. Maritime Policy \& Management. 45(3), 403417.

Lavissière, A., Rodrigue, J. 2017. Free ports: towards a network of trade gateways. Shipping and Trade. 2:7.

Layaa, J., Dullaert, W.2014.Measuring and analysing terminal capacity in East Africa: The case of the seaport of Dar es Salaam. Maritime Economics and Logistics 16(2), 141-164.

Laxe, F.G., Sánchez, R. J., Garcia-Alonso, L. 2016.The adaptation process in port governance: the case of the Latin countries in South America and Europe. Shipping and Trade. 1(14), 1-20

Lättilä, L., Henttu, V., Hilmola,O. 2013. Hinterland operations of sea ports do matter: Dry port usage effects on transportation costs and CO2 emissions. Transport Research Part E. 55, 23-42.

Leachman, R.C., Jula, P. 2011. Congestion analysis of waterborne, containerized imports from Asia to the United States. Transport Research Part E. 47(6), 992-1004.

Leachman, R.C., Jula, P.2012. Estimating flow times for containerized imports from Asia to the United States through the Western rail network. Transport Research Part E. 48(1), 296-309.

Lee, B.K., Low, J.M.W., Kim, K. H. 2015. Comparative evaluation of resource cycle strategies on operating and environmental impact in container terminals. Transportation Research Part D. 41, 118-135. Transportation Research Part D. 41, 118-135.

Lee, P.T., Lun, Y.H.V., Lai, K., Cheng, T.C.E. 2016. Maritime logistics and port connectivity in the globalised economy. Transportation Research Part E, 95, 323-325.

Lee, C., Miller, J. S. 2017. A probability-based indicator for measuring the degree of multimodality in transportation investments. Transportation Research Part A.103, 377-390

Lee, D., Jin, J. G., 2013. Feeder vessel management at container transshipment terminals. Transport Research Part E. 49(1), 201-216.

Lee, D., Jin, J. G., Chen, J.H. 2012. Terminal and yard allocation problem for a container transshipment hub with multiple terminals. Transport Research Part E. 48(2), 516-528.

Lee, D., Lim, S., Choi, K. 2017. Port privatization under Cournot vs. Bertrand competition: a thirdmarket approach. Maritime Policy \& Management. 44(6), 761-778.

Lee, E., Oduor, P.G., Farahmand, K., Tolliver, D. 2014. A coupled linear programming model with geospatial dynamic trip assignment for global-scale intermodal transportation. Maritime Economics and Logistics. 16(1), 33-54.

Lee, E., Song, D. 2010. Knowledge management for maritime logistics value: discussing conceptual issues. Maritime Policy \& Management. 37(6), 563-583.

Lee, G., Lee, M. 2017. Estimation of the shore excursion expenditure function during cruise tourism in Korea. Maritime Policy \& Management. 44(4), 524-535.

Lee, M., Yoo, S. 2015. Public preference for the attributes of the marina port in Korea: a choice experiment study. Maritime Policy \& Management. 42(5), 516-532.

Lee, P.T., Chang, Y., Lai, K., Lun, V.Y.H., Cheng, T.C.E. 2018. Green shipping and port operations. Transportation Research Part D, 61, 231-233. 
Lee, P.T.W., Cheong, I. 2013. Clustering logistics with ports and shipping services in the time of troubled waters and free trade era. Maritime Policy \& Management. 40(2), 95-99.

Lee, P.T.W., Flynn, M. 2011. Charting a New Paradigm of Container Hub Port Development Policy: The Asian Doctrine. Transport Reviews. 31(6), 791-806.

Lee, P.T.W., Lee, T. 2012. A new lease charging system for Busan container terminals: a historical case study. Maritime Policy \& Management. 39(1), 91-105.

Lee, S., Lim, H., Kim, H. 2017. Forecasting container port volume: implications for dredging. Maritime Economics and Logistics. 19(2) 296-314.

Lee, T., Wu, C., Lee, P. T.W. 2011. Impacts of the ECFA on seaborne trade volume and policy development for shipping and port industry in Taiwan. Maritime Policy \& Management. 38(2), 169-189.

Lee, T., Yeo, G., Thai, V. V. 2014. Environmental efficiency analysis of port cities: Slacks-based measure data envelopment analysis approach. Transport Policy.33, 82-88.

Legato, P., Canonaco, P., Mazza, R.M. 2009. Yard crane management by simulation and optimisation. Maritime Economics and Logistics. 11(1), 36-57.

Lei, T. L., Church, R. L. 2011. Locating short-term empty-container storage facilities to support port operations: A user optimal approach. Transport Research Part E. 47(5), 738-754.

Levine, B., Nozick, L., Jones, D., 2009. Estimating an origin-destination table for US imports of waterborne containerized freight. Transportation Research Part E. 45(4), 611-626.

Li, K. X., Luo, M., Yang, J. 2012.Container port systems in China and the USA: a comparative study. Maritime Policy \& Management. 39(5), 461-478.

Li, L., Negenborn, R. R, Schutter, B.D. 2017. Distributed model predictive control for cooperative synchromodal freight transport. Transportation Research Part E. 105, 240-260

Li, L., Wang, B., Cook, D.P.2014. Enhancing green supply chain initiatives via empty container reuse. Transport Research Part E.70, 190-204.

Li, N., Chen, G., Govindan, K., Jin, Z. 2018. Disruption management for truck appointment system at a container terminal: A green initiative. Transportation Research Part B.61, 261-273.

Li, S., Negenborn, R.R., Lodewijks, G. 2017. Closed-loop coordination of inland vessels operations in large seaports using hybrid logic-based benders decomposition. Transportation Research Part E. 97, 1-21.

Liao, C., Tseng, P., Lu, C. 2009. Comparing carbon dioxide emissions of trucking and intermodal container transport in Taiwan. Transportation Research Part D. 14(7), 493-496.

Liu, C., Wang, J., Zhang, H. 2018. Spatial heterogeneity of ports in the global maritime network detected by weighted ego network analysis. Maritime Policy \& Management. 45(1), 89-104.

Lin, D., Chiang, C. 2017. The Storage Space Allocation Problem at a Container Terminal. Maritime Policy \& Management. 44(6), 685-704.

Lin, D., Huang, K. 2017. An equilibrium-based network model for international container flows. Maritime Policy \& Management. 44(8), 1034-1055.

Liu, D., Ge, Y. 2018. Modeling assignment of quay cranes using queueing theory for minimizing CO2 emission at a container terminal. Transportation Research Part D. Part A. 61, 140-151.

Liu, N., Gong, Z., Xiao, X. 2018. Disaster prevention and strategic investment for multiple ports in a region: cooperation or not. Maritime Policy \& Management. 45(5), 585-603

Liu, Q., Lim, S.H.2017.Toxic air pollution and container port efficiency in the USA. Maritime Economics and Logistics. 19(1) 94-105.

Liu, M., Lee, C., Zhang, Z., Chu, C. 2016. Bi-objective optimization for the container terminal integrated planning. Transportation Research Part B.93, 720-749. 
Liu, S., Chen, H., Han, W., Lin, Y. 2018. Optimal concession contracts for landlord port authorities to maximize fee revenues with minimal throughput requirements. Transportation Research Part E.109, 239-260.

Liu, Z., Meng, Q., Wang, S., Sun, Z. 2014.Global intermodal liner shipping network design. Transport Research Part E.61, 28-39.

Loh, H.S., Thai, V.V. 2016. Managing port-related supply chain disruptions (PSCDs): a management model and empirical evidence. Maritime Policy \& Management. 43(4), 436-455.

Low, J.M.W., Lam, S.W., Tang, L. C.2009. Assessment of hub status among Asian ports from a network perspective. Transportation Research Part A. 43(6), 593-606.

Low, J. M. W. 2010.Capacity investment and efficiency cost estimations in major East Asian ports. Maritime Economics and Logistics. 12(4), 370-391.

Low, J.M. W., Tang, L. C. 2012. Network effects in the East Asia container ports industry. Maritime Policy \& Management. 39(4), 369-386.

Lu, C., Lai, P., Chiang, Y. 2016.Container terminal employees' perceptions of the effects of sustainable supply chain management on sustainability performance. Maritime Policy \& Management. 43(5), 597-613.

Lu, C., Shang, K., Lin, C. 2016.Examining sustainability performance at ports: port managers' perspectives on developing sustainable supply chains. Maritime Policy \& Management. 43(8), 909-927.

Lu, H., Mu, W. 2016. A slot reallocation model for containership schedule adjustment. Maritime Policy \& Management. 43(1), 136-157.

Lu, H., Mu, W. 2016. Evaluation of alternative scenarios of labour flexibility for dockworkers in maritime container terminals. Maritime Policy \& Management. 43(3), 371-385.

Lugt, L.M., Langen, P.W., Hagdorn, L. 2017. Strategic beliefs of port authorities Transport Reviews. 37(4), 412-441.

Lun, Y.H., Lai, K., Wong, C.W.Y., Cheng, T.C.E. 2015. Greening propensity and performance implications for logistics service providers. Transportation Research Part E. 74, 50-62.

Luna, J.H., Mar-Ortiz, J., Gracia,M.D., Morales-Ramı'rez, D. 2018. An efficiency analysis of cargo-handling operations at container terminals. Maritime Economics and Logistics, 20(2), 190-210.

Luo, M., Liu, L., Gao, F. 2012. Post-entry container port capacity expansion. Transport Research Part B. 46(1), 120- 138.

Luo, J., Wu, Y. 2015. Modelling of dual-cycle strategy for container storage and vehicle scheduling problems at automated container terminals. Transportation Research Part E.79, 4964.

Maca'rio, M.R.M.R., Costa, J.D., Ribeiro, J.A.M. 2015. Cross-sector Analysis of Four Renegotiated Transport PPPs in Portugal. Transport Reviews. 35(2), 226-244.

Maloni, M.J., Gligor, D.M., Lagoudis, I. N. 2016.Linking ocean container carrier capabilities to shipper-carrier relationships: a case study. Maritime Policy \& Management. 43(8), 959-975.

Mamatok, Y., Jin, C. 2017. An integrated framework for carbon footprinting at container seaports: the case study of a Chinese port. Maritime Policy \& Management. 44(2), 208-226.

Maparu, T.S., Mazumder, T. N.2017. Transport infrastructure, economic development and urbanization in India (1990-2011): Is there any causal relationship? Transportation Research Part A.100, 319-336.

Maragkogianni, A., Papaefthimiou, S. 2015. Evaluating the social cost of cruise ships air emissions in major ports of Greece. Transportation Research Part D. 36, 10-17. 
Marenco, L., Cantillo, V. 2015. A framework to evaluate particulate matter emissions in bulk material ports: case study of Colombian coal terminals. Maritime Policy \& Management. 42(4), 335-361.

Marlow, P.B. 2010. Maritime security: an update of key issues. Maritime Policy \& Management. 37(7), 667-676.

Marques, R.C., Fonseca, Á. 2010. Market structure, privatisation and regulation of Portuguese seaports. Maritime Policy \& Management. 37(2), 145-161.

Martín, E., Salvador, J., Saurí, S. 2014.Storage pricing strategies for import container terminals under stochastic conditions. Transport Research Part E.68, 118-137.

Martinez, C., Steven, A. B., Dresner, M. 2016. East Coast vs. West Coast: The impact of the Panama Canal's expansion on the routing of Asian imports into the United States. Transportation Research Part E, 91, 274-289.

Martínez-López, A., Munín-Doce, A., García-Alonso, L. 2015. A multi-criteria decision method for the analysis of the Motorways of the Sea: the application to the case of France and Spain on the Atlantic Coast. Maritime Policy \& Management. 42(6), 608-631.

Martino, M.D., Carbone, V., Morvillo, A. 2015.Value creation in the port: opening the boundaries to the market. Maritime Policy \& Management. 42(7), 682-698.

Matsushima, N., Takauchi, K. 2014. Port privatization in an international oligopoly. Transport Research Part B. 67,382-397.

McArthur, Osland, L. 2013. D.P., Ships in a city harbour: An economic valuation of atmospheric emissions. Transport Research Part D. 21, 47-52.

McIntosh, C.R., Skalberg, R. K. 2009. A statistical approach to US harbor maintenance tax rates and replacement user fees. Maritime Economics and Logistics. Maritime Economics and Logistics. 12(3), 263-279.

McIntosh, C.R., Wilmot, N. A., Skalberg, R.K. 2015. Paying for harbor maintenance in the US: Options for moving past the Harbor Maintenance Tax. Transportation Research Part A. 74, 210221.

Mckinnon, A.C. 2016. Freight Transport Deceleration: Its Possible Contribution to the Decarbonisation of Logistics. Transport Reviews. 36(4), 418-436.

Mclaughlin, H., Fearon, C. 2013.Understanding the development of port and regional relationships: a new cooperation/ competition matrix. Maritime Policy \& Management. 40(3), 278-294.

Medal-Bartual, A., Molinos-Senante, M., Sala-Garrido, R. 2014. Medal-Bartual, A., MolinosSenante, M., Sala-Garrido, R. 2016. Productivity change of the Spanish Port System: impact of the economic crisis. Maritime Policy \& Management. 43(6), 683-705.

Mellin, A., Rydhed, H. 2011.Swedish ports' attitudes towards regulations of the shipping sector's emissions of CO2. Maritime Policy \& Management. 38(4), 437-450.

Meng, Q., Wang, S. 2011. Intermodal hub-and-spoke network design: Incorporating multiple stakeholders and multi-type containers. Transport Research Part B. 45(5), 724-742.

Meng, Q., Wang, S. 2011. Liner shipping service network design with empty container repositioning. Transport Research Part E. 47(5), 695-708.

Meng, Q., Wang, T., Wang, S. 2015.Multi-period liner ship fleet planning with dependent uncertain container shipment demand. Maritime Policy \& Management. 42(1), 43-67.

Merico, E., Gambaro, A., Argiriou, A., Alebic-Juretic, A., Barbaro, E., Cesari, D. Chasapidis, L., Dimopoulos, S., Dinoi, A., Donateo, A., Giannaros,C., Gregoris,E., Karagiannidis,A., Konstandopoulos,A.G., Ivoševic,T., Liora, N., Melas,D., Mifka,B., Orlic,I., Poupkou,A., 
Sarovic,K., Tsakis, A., Giua,R., Pastore,T., Nocioni,A., Contin,D.2017. Atmospheric impact of ship traffic in four Adriatic-Ionian port-cities: Comparison and harmonization of different approaches. Transportation Research Part D. 50, 431-445.

Merkel, A., Holmgren, J. 2017. Dredging the depths of knowledge: Efficiency analysis in the maritime port sector. Transport Policy. 60, 63-74.

Metaparti, P. 2010. Rhetoric, rationality and reality in post-9/11 maritime security. Maritime Policy \& Management. 37(7), 723- 736.

Min, H., Ahn, S., Lee, H., Park, H. 2017. An integrated terminal operating system for enhancing the efficiency of seaport terminal operators. Maritime Economics and Logistics. 19(3), 428450.

Min, H., Jun, C. 2014. Public-private partnerships for the development of port hinterlands and their ramifications for global supply chain management. Maritime Economics and Logistics 16(3), 250-275.

Moini, N., Boile, M., Theofanis, S., Laventhal, W. 2012. Estimating the determinant factors of container dwell times at seaports. Economics and Logistics. 14(2), 162-177.

Monaco, M. F., Moccia, L., Sammarra, M. 2009. Operations Research for the management of a transshipment container terminal: The Gioia Tauro case. Maritime Economics and Logistics. 11(1), 7-35.

Mondragon, A.E. C., Mondragon, C. E. C., Coronado, E.S. 2017. ICT adoption in multimodal transport sites: Investigating institutional-related influences in international seaports terminals. Transportation Research Part A. 97, 69-88.

Monios, J. 2015. Identifying Governance Relationships between Intermodal Terminals and Logistics Platforms. Transport Reviews. 35(6), 767-791.

Monios, J., Wilmsmeier, G. 2012. Giving a direction to port regionalisation. Transport Research Part A. 46(10), 1551- 1561.

Monios, J., Wilmsmeier, G. 2012. Port-centric logistics, dry ports and offshore logistics hubs: strategies to overcome double peripherality? Maritime Policy \& Management. 39(2), 207-226.

Monios, J. Wilmsmeier, G. 2013. The role of intermodal transport in port regionalisation. Transport Policy. 30, 161-172.

Monios, J., Wilmsmeier, G. 2014. The Impact of Container Type Diversification on Regional British Port Development Strategies. Transport Reviews. 34(5), 583-606.

Monios, J., Wilmsmeier, G., Ng, A.K. Y. 2018. Port system evolution - the emergence of secondtier hubs. Maritime Policy \& Management. In Press, Corrected Proof.

Montes, C.P., Seoane, M.J.F., Laxe, F.G. 2012. General cargo and containership emergent routes: A complex networks description. Transport Policy. 24, 126-140.

Moon, D.S., Woo, J. K . 2014. The impact of port operations on efficient ship operation from both economic and environmental perspectives. Maritime Policy \& Management. 41(5), 444-461.

Moon, I., Hong, H. 2016. Repositioning of empty containers using both standard and foldable containers. Maritme Economics and Logistics. 18(1), 61-77.

Moon, I. K., Qiu, Z.B., Wang, J. H.2015. A combined tramp ship routing, fleet deployment, and network design problem. Maritime Policy \& Management. 42(1), 68-91

Moon, I., Ngoc, A.D., Konings, R. 2013. Foldable and standard containers in empty container repositioning. Transport Research Part E. 49(1), 107-127.

Moya, J.M., Valero, M.F. 2017. Port choice in container market: a literature review. Transport Reviews. 37(3), 300-321. 
Munim, Z.H., Saeed, N., Larsen, O.I. 2018. 'Tool port' to 'landlord port': a game theory approach to analyse gains from governance model transformation. Maritime Policy \& Management. In Press, Corrected Proof.

Munim, Z.H., Schramm, H. 2018. The impacts of port infrastructure and logistics performance on economic growth: the mediating role of seaborne trade. Shipping and Trade .3(1).

Munisamy, S .2010.Timber terminal capacity planning through queuing theory. Maritime Economics and Logistics. 12(2), 147-161.

Musso, A., Piccioni, C., Voorde, E. V. 2013. Italian seaports' competition policies: Facts and figures. Transport Policy. 25, 198-209.

Nam, H., Song, D. 2011. Defining maritime logistics hub and its implication for container port. Maritime Policy \& Management. 38(3), 269-292.

Nazemzadeh, M., Vanelslander, T. 2015.The container transport system: Selection criteria and business attractiveness for North-European ports. Maritime Economics and Logistics. 17(2), 221-245.

Ng, A.K.Y. 2009. Competitiveness of short sea shipping and the role of port: the case of North Europe. Maritime Policy \& Management. 235-251.

Ng, A.K. Y., Gujar, G.C. 2009. Government policies, efficiency and competitiveness: The case of dry ports in India. Transport Policy. 16(5), 232-239.

Ng, A.K. Y., Wong, K., Shou, E.C., Jiang, C. 2018. Geography and institutional change: insights from a container terminal operator. Maritime Economics and Logistics, 1-19.

Nguyen, H., Chin, A., Tongzon, J., Bandara, M. 2016. Analysis of strategic pricing in the port sector: The network approach. Maritime Economics and Logistics. 18(3), 264-281.

Nguyen, H., Nghiem, H., Chang, Y. 2018. A regional perspective of port performance using metafrontier analysis: the case study of Vietnamese ports. Maritime Economics and Logistics. 20(1), 112-130.

Nguyen, H., Nguyen, H., Chang, Y., Chin, A.T. H., Tongzon, J. 2016. Measuring port efficiency using bootstrapped DEA: the case of Vietnamese ports. Maritime Policy \& Management. 43(5), 644-659.

Nguyen, L., Notteboom, T. 2018. The relations between dry port characteristics and regional porthinterland settings: findings for a global sample of dry ports. Maritime Policy \& Management. In Press, Corrected Proof.

Nishimura, E., Imai, A., Janssens, G.K., Papadimitriou, S. 2009.Container storage and transshipment marine terminals. Transportation Research Part E. 45(5), 771-786.

Norsworthy, M., Craft, E. 2013. Emissions reduction analysis of voluntary clean truck programs at US ports. Transport Research Part D. 22, 23-27.

Norzaidi, M.D., Chong, S.C., Murali, R., Salwani, M.I. 2009. Towards a holistic model in investigating the effects of intranet usage on managerial performance: a study on Malaysian port industry. Maritime Policy \& Management. 36(3), 269- 289.

Notteboom, T. 2011. An application of multi-criteria analysis to the location of a container hub port in South Africa. Maritime Policy \& Management. 38(1), 51-79.

Notteboom, T.E., Pallis, A.A., Langen, P.W. D., Papachristou, A. 2013. Advances in port studies: the contribution of 40 years Maritime Policy \& Management. Policy \& Management. 40(7), 636-653.

Notteboom, T., Rodrigue, J. 2012. The corporate geography of global container terminal operators. Maritime Policy \& Management. 39(3), 249-279. 
Notteboom, T., Verhoeven, P., Fontanet, M. 2012.Current practices in European ports on the awarding of seaport terminals to private operators: towards an industry good practice guide. Maritime Policy \& Management. 39(1), 107-123.

Nünez-Sanchez, R. 2013. Marginal Costs, Price Elasticities of Demand, and Second-best Pricing in a Multiproduct Industry: An Application for Spanish Port Infrastructure. Transport Economics and Policy. 47(3), 349-369.

Núñez-Sánchez, R., Coto-Millán, P. 2012. The impact of public reforms on the productivity of Spanish ports: A parametric distance function approach. Transport Policy. 24, 99-108.

Núñez-Sánchez, R., Jara-Díaz, S., Coto-Millán, P. 2011.Public regulation and passengers importance in port infrastructure costs. Transport Research Part A. 45(7), 653-666.

Nwanosike, F.O., Tipi, N.S., Warnock-Smith, D. 2016. Productivity change in Nigerian seaports after reform: a Malmquist productivity index decomposition approach. Maritime Policy \& Management. 43(7), 798-811.

Odchimar, A., Hanaoka, S. 2017. Intermodal freight network incorporating hub-and-spoke and direct calls for the archipelagic Philippines. Maritime Economics and Logistics. 19(2), 352378.

Okorie, C., Tipi, N., Hubbard, N. 2016. Analysis of the potential contribution of value-adding services (VAS) to the competitive logistics strategy of ports. Maritime Economics and Logistics. 18(2), 158-173.

Oliveira, G.F., Cariou, P. 2011. A DEA study of the efficiency of 122 iron ore and coal ports and of 15/17 countries in 2005. Maritime Policy \& Management. 38(7), 727-743.

Oliveira, G.F., Cariou, P. 2015. The impact of competition on container port (in) efficiency. Transportation Research Part A. 78, 124-133.

Olivo, A., Francesco, M.D., Zuddas, P. 2013. An optimization model for the inland repositioning of empty containers. Maritime Economics and Logistics. 15(3), 309-331.

Onstein, A.T. C., Tavasszy, L. A.., Damme, D. A. 2018. Factors determining distribution structure decisions in logistics: a literature review and research agenda. Transport Reviews. In Press, Corrected Proof.

Onut, S., Tuzkaya, U.R., Torun, E. 2011. Selecting container port via a fuzzy ANP-based approach: A case study in the Marmara Region, Turkey. Transport Policy. 18(1), 182-193.

Osei -Kyei, R., Chan, A.P.C. 2016. Developing Transport Infrastructure in Sub-Saharan Africa through Public -Private Partnerships: Policy Practice and Implications. Transport Reviews. 36(2), 170-186.

Osthorst, W., Mänz, C. 2012. Types of cluster adaptation to climate change. Lessons from the port and logistics sector of Northwest Germany. Maritime Policy \& Management. 39(2), 227-248.

Öztürk, C., Sargut, F.Z., Örnek, M. A., Eliiy, D.T. 2017. Optimisation and heuristic approaches for assigning inbound containers to outbound carriers. Maritime Policy \& Management. 44(7), 825-836.

Padilha, F., Ng, A.K.Y. 2012.The spatial evolution of dry ports in developing economies: The Brazilian experience. Economics and Logistics. 14(1), 99-121.

Paflioti, P., Vitsounis, T.K., Teye, C., Bell, M.G.H., Tsamourgelis, I. 2017. Box dynamics: A sectoral approach to analyse containerized port throughput interdependencies. Transportation Research Part A.106, 396-413.

Pagano, A.M., Wang, G.W.Y., Sánchez, O.V. 2013. Impact of privatization on port efficiency and effectiveness: results from Panama and US port. Maritime Policy \& Management. 40(2), 100115. 
Pallis, A.A., Parola, F., Acciaro, M. 2017. Empirical methods in the study of maritime economics. Maritime Economics and Logistics. 19(2), 189-195.

Pallis, A. A., Parola, F., Satta, G., Notteboom, T. E. 2018. Private entry in cruise terminal operations in the Mediterranean Sea. Maritime Economics and Logistics, 20(1), 1-28.

Pallis, A.A., Vitsounis, T. K., Langen, P.W.D. 2010. Port Economics, Policy and Management: Review of an Emerging Research Field. Transport Reviews. 30(1), 115- 161.

Pallis, A.A., Vitsounis, T. K., Langen, P.W.D., Notteboom, T.E. 2011.Port Economics, Policy and Management: Content Classification and Survey. Transport Reviews. 31(4), 445-471.

Panayides, P.M., Maxoulis, C.N., Wang, T., Ng, K.Y.A. 2009. A critical analysis of DEA applications to seaport economic efficiency measurement. Transport Reviews. 29(2), 183-206.

Panayides, P.M., Parola, F., Lam, J.S.L. 2015. The effect of institutional factors on public-private partnership success in ports. Transportation Research Part A. 71, 110-127.

Panayides, P.M., Song, D. 2013. Maritime logistics as an emerging discipline. Maritime Policy \& Management. 40(3), 295-308.

Pant, R., Barker, K., Grant, F. H., Landers, T .L. 2011. Interdependent impacts of inoperability at multi-modal transportation container terminals. Transport Research Part E. 47(5), 722-737.

Pantouvakis, A., Dimas, A. 2010. Does ISO 9000 series certification matter for the financial performance of ports? Some preliminary findings from Europe. Maritime Policy \& Management. 37(5), 505-522.

Papa, P. 2013.US and EU strategies for maritime transport security: A comparative perspective. Transport Policy. 28, 75-85.

Papaefthimiou, S., Sitzimis, I., Andriosopoulos, K. 2017. A methodological approach for environmental characterization of ports. Maritime Policy \& Management. 44(1), 81-93.

Pardali, A., Kounoupas, E., Lainos ,I. 2016. Can clusters be bi-polar? Exploring the case of the Piraeus port-maritime cluster. Maritime Policy \& Management. 43(6), 706-719.

Park, H., Chang, Y., Zou, B. 2018.Emission control under private port operator duopoly. Transportation Research Part E.114, 40-65.

Park, J.S., Seo, Y. 2016. The impact of seaports on the regional economies in South Korea: Panel evidence from the augmented Solow model. Transportation Research Part E 85, 107-119.

Parola, F., Lam, J. S. L. 2018. An empirical investigation of logistics infrastructure projects in emerging economies. Maritime Economics and Logistics, 20(1), 48-71.

Parola, F., Pallis, A.A., Risitano, M., Ferretti, M. 2018. Marketing strategies of Port Authorities: A multi-dimensional theorization. Transportation Research Part A.111, 199-212.

Parola, F., Satta, G., Caschili,S. 2014 .Unveiling co-operative networks and 'hidden families' in the container port industry. Maritime Policy \& Management. 41(4), 384-404.

Parola, F., Sciomachen, A. 2009. Modal split evaluation of a maritime container terminal. Maritime Economics and Logistics. 11(1), 77- 97.

Parola, F., Tei, A., Ferrari, C. 2012. Managing port concessions: evidence from Italy. Maritime Policy \& Management. 39(1), 45-61.

Parthibaraj, C.S., Palaniappan, P.L.K., Gunasekaran, A., Subramanian, N. 2017. Multi-agent system with iterative auction mechanism for master bay plan problem in marine logistics. Maritime Policy \& Management. 44(6), 705-726.

Paul, J.A., MacDonald, L. 2017. An empirical analysis of US vessel-related port accidents (20022012): Impact of union membership and port efficiency on accident incidence and economic damage. Maritime Economics and Logistics. 19(4), 723-748. 
Paul, J.A., MalonI, M. J. 2010. Modeling the effects of port disasters. Maritime Economics and Logistics. 12(2), 127-146.

Pawlik, T., Stemmler, L., Baird, A.J., Helch, M. 2011. The value of container terminal investment to ocean carrier strategy. Maritime Economics and Logistics. 13(3), 319-341.

Paz, M., Orive, A., Cancelas, N. 2015. Use of the Delphi method to determine the constraints that affect the future size of large container ships. Maritime Policy and Management, 42(3), 263277.

Penco, L., Vaio, A. D. 2014. Monetary and non-monetary value creation in cruise port destinations: an empirical assessment. Maritime Policy \& Management. 41(5), 501-513.

Perez-Mesa, J.C., Galdeano-Go'mez, E., Andujar, J.A. S. 2012. Logistics network and externalities for short sea transport: An analysis of horticultural exports from southeast Spain. Transport Policy. 24, 188-198.

Perez-Mesa, J.C., Céspedes-Lorente, J.J., Salinas Andújar, J.A., 2010. Transport Reviews. 30(4), 451-471.

Perrotti, D.E., Sánchez, R.J. 2012. Looking into the future: big full containerships and their arrival to South American ports. Maritime Policy \& Management. 39(6), 571-588.

Petering, M. E.H. 2009. Effect of block width and storage yard layout on marine container terminal performance. Transportation Research Part E. 45(4), 591-610.

Petering, M.E.H. 2011. Decision support for yard capacity, fleet composition, truck substitutability, and scalability issues at seaport container terminals. Transport Research Part E. 47(1), 85-103.

Pettit, S. J., Beresford, A. K. C. 2009. Port development: from gateways to logistics hubs. Maritime Policy \& Management. 36(3), 253- 267.

Pérez, I., González, M.M., Jiménez, J.L. 2017. Size matters? Evaluating the drivers of waste from ships at ports in Europe. Transportation Research Part D. 57, 403-412.

Pilcher, N., Tseng, P. 2017. Can we really measure the impact of port governance reform? Maritime Policy \& Management. 44(8), 981-994.

Pinto, M. M.O., Goldberg, D. J.K., Stupello, B., Haley, C.W. 2010. Regulation and price setting of pilotage services in Brazil. Maritime Economics and Logistics. 12(4), 430-442.

Pinto, M. M. O., Goldberg, D.J.K., Cardoso, J.S.L. 2017. Benchmarking operational efficiency of port terminals using the OEE indicator. Maritime Economics and Logistics. 19(3), 504-517.

Polat, O., Günther, H., Kulak,O. 2014..The feeder network design problem: Application to container services in the Black Sea region. Maritime Economics and Logistics. 16(3), 343-369.

Psaraftis, H.N., Pallis, A.A. 2012. Concession of the Piraeus container terminal: turbulent times and the quest for competitiveness. Maritime Policy \& Management. 39(1), 27-43.

Qi, X., Song, D. 2012. Minimizing fuel emissions by optimizing vessel schedules in liner shipping with uncertain port times. Transport Research Part E. 48(4), 863-880.

Qiu, X., Lam, J. S.L., Huang, G. Q. 2015. A bilevel storage pricing model for outbound containers in a dry port system. Transportation Research Part E. 73, 65-83.

Qu, C., Wang,G.W.Y., Zeng,Q. 2017. Modelling port subsidy policies considering pricing decisions of feeder carriers. Transportation Research Part E.99, 115-133.

Rahman, N.S.F.A., Salleh, N.H.M., Najib, A.F.A., Lun, V.Y. H. 2016. A descriptive method for analysing the Kra Canal decision on maritime business patterns in Malaysia. Shipping and Trade. Shipping and Trade. 1(13), 1-16.

Ramos-Real, F.J., Tovar, B. 2010. Productivity Change and Economies of Scale in Container Port Terminals. Transport Economics and Policy. 44(2), 231- 246. 
Rashed, Y., Meersman, H., Voorde, E. V., Vanelslander, T. 2017. Short-term forecast of container throughout: An ARIMA-intervention model for the port of Antwerp. Maritime Economics and Logistics. 19(4) 749-764.

Reeven, P. 2010.The Effect of Competition on Economic Rents in Seaports. Transport Economics and Policy. 44(1), 79- 92.

Reinhardt, L. B., Plum, C.E.M., Pisinger, D., Sigurd, M.M., Vial, G.T.P. 2016. The liner shipping berth scheduling problem with transit times. Transportation Research Part E. 86, 116-128.

Ren, J., Dong, L., Sun, L. 2018. Competitiveness prioritization of container ports of background China's Belt and Road Initiative. Transport Reviews. 38(4), 436-456.

Reynaerts, J. 2010. Simulating mergers between stevedores. Maritime Economics and Logistics. 12(1), 8-35.

Riessen, B., Negenborn, R.R., Lodewijks, G., Dekker, R. 2015. Impact and relevance of transit disturbances on planning in intermodal container networks using disturbance cost analysis. Maritime Economics and Logistics. 17(4), 440-463.

Rios, C.A.M., Sousa, R.F. 2014.Cluster analysis of the competitiveness of container ports in Brazil. Transport Research Part A. 69, 423-431.

Ritchie, W.J., Melnyk, S.A., Ni, J.Z. 2017. Environmental standard adoption in Marinas: A spatiotemporal analysis of a special form of maritime transportation hubs. Transportation Research Part D. 55, 1-11.

Rocha, C.H., Britto, P.A.P. 2010.Securitisation of leases of port areas and installations in Brazil. Maritime Policy \& Management. 37(2), 163-174.

Rodrigue, J., Notteboom, T. 2015. Looking inside the box: evidence from the containerization of commodities and the cold chain. Maritime Policy \& Management. 42(3), 207-227.

Rodrigue, J., Notteboom, T., Pallis, A.A. 2011. The financialization of the port and terminal industry: revisiting risk and embeddedness. Maritime Policy \& Management. 38(2), 191-213.

Rodrigues, V. S., Pettit, S., Harris, I., Beresford, A., Piecyk, M., Yang, Z., Ng, A. 2015. UK supply chain carbon mitigation strategies using alternative ports and multimodal freight transport operations. Transportation Research Part E. 78, 40-56.

Rodriguez-Alvarez, A., Tovar, B. 2012. Have Spanish port sector reforms during the last two decades been successful? A cost frontier approach. Transport Policy. 24, 73-82.

Rodriguez-Alvarez, A., Tovar, B., Wall, A. 2011.The Effect of Demand Uncertainty on Port Terminal Costs. Transport Economics and Policy. 45(2), 303-328.

Roso, V., Lumsden, K. 2010. A review of dry ports. Maritime Economics and Logistics. 12(2), 196-216.

Rødseth, K.L., Wangsness, P.B., Schøyen, H. 2018.How do economies of density in container handling operations affect ships' time and emissions in port? Evidence from Norwegian container terminals. Transportation Research Part D.59, 385-399.

Ruan, X., Feng, X., Pang, K. 2018. Development of port service network in OBOR via capacity sharing: an idea from Zhejiang province in China. Maritime Policy \& Management. 45(1), 105124.

Saeed, N. 2009. An analysis of carriers' selection criteria when choosing container terminals in Pakistan. Maritime Economics and Logistics. 11(3), 270-288.

Saeed, N., Larsen, O.I. 2010. Container terminal concessions: A game theory application to the case of the ports of Pakistan. Maritime Economics and Logistics. 12(3), 237-262. 
Sakalayen, Q., Chen, P. S., Cahoon, S. 2017. The strategic role of ports in regional development: conceptualising the experience from Australia. Maritime Policy \& Management. 44(8), 933955.

Sambracos, E., Maniati, M.2012.Competitiveness between short sea shipping and road freight transport in mainland port connections; the case of two Greek ports. Maritime Policy \& Management. 39(3), 321-337.

Sanabra, M.C., Santamaría, J.J.U., Osés, F. X. M. 2014. Manoeuvring and hotelling external costs: enough for alternative energy sources? Maritime Policy \& Management. 41(1), 42-60.

Santos, A.M.P., Mendes, J.P., Soares, C. G. 2016. A dynamic model for marginal cost pricing of port infrastructures. Maritime Policy \& Management. 43(7), 812-829.

Santos, A.M.P., Salvador, R., Dias, J.C. Q., Soares, C.G. 2018. Assessment of port economic impacts on regional economy with a case study on the Port of Lisbon. Maritime Policy \& Management. 45(5), 684-698.

Santos, A. M. P., Salvador, R., Soares, C. G. 2018. A dynamic view of the socioeconomic significance of ports. Maritime Economics and Logistics, 20(2), 169-189.

Sanz-Blas, S., Carvajal-Trujillo, E., Buzova, D. 2017. Assessing cruise port of call performance: a passenger-based approach using PLS modelling. Maritime Policy \& Management. 44(8), 967980.

Satta, G. 2017. Initial public offerings in the port industry: exploring the determinants of underpricing. Maritime Policy \& Management. 44(8), 1012-1033.

Satta, G., Notteboom, T., Parola, F., Persico, L. 2017. Determinants of the long-term performance of initial public offerings (IPOs) in the port industry. Transportation Research Part A.103, 135153.

Satta, G., Parola, F., Caschili, S. 2014. Dealing with uncertainty and volatility in the port industry network: social and instrumental antecedents of "clique" survival. Maritime Policy \& Management. 41(7), 615-633.

Satta, G., Persico, L. 2015. Entry mode choices of rapidly internationalizing terminal operators: The determinants of the degree of control on foreign ventures. Maritime Economics and Logistics. 17(1), 97-126.

Saurí, S., Martín, E. 2011. Space allocating strategies for improving import yard performance at marine terminals. Transport Research Part E. 47(6), 1038-1057.

Saz-Salazar, S., García-Menéndez, L. 2016. Port expansion and negative externalities: a willingness to accept approach. Maritime Policy \& Management. 43(1), 59-83.

Schellinck, T., Brooks, M. R. 2014. Improving port effectiveness through determinance/performance gap analysis. Maritime Policy \& Management. 41(4), 328-345.

Schepler, X., Balev, S., Michel, S., Sanlaville, É. 2017. Global planning in a multi-terminal and multi-modal maritime container port. Transportation Research Part E.100, 38-62.

Schipper, C.A., Vreugdenhil, H., de Jong, M.P.C. 2017. A sustainability assessment of ports and port-city plans: Comparing ambitions with achievements. Transportation Research Part D. 57, 84- 111.

Schøyen, H., Odeck, J. 2013. The technical efficiency of Norwegian container ports: A comparison to some Nordic and UK container ports using Data Envelopment Analysis (DEA). Maritime Economics and Logistics. 15(2), 197-221.

Schulte, F., Lalla-Ruiz,E., González-Ramírez, R.G., Voß, S. 2017. Reducing port-related empty truck emissions: A mathematical approach for truck appointments with collaboration. Transportation Research Part E. 105, 195-212. 
Sciberras, E.A., Zahawi, B., Atkinson, D.J. 2017. Reducing shipboard emissions - Assessment of the role of electrical technologies. Transportation Research Part D. 51, 227-239.

Seo, Y., Dinwoodie, J., Roe, M. 2015. Measures of supply chain collaboration in container logistics. Maritime Economics and Logistics. 17(3), 292-314.

Seo, Y., Park, J.S. 2018. The estimation of minimum efficient scale of the port industry. Transport Policy, 49, 168-175.

Serebrisky, T., Sarriera, J. M., Suárez-Alemán, A., Araya,G., Briceño-Garmendía,C., Schwartz,J. 2016. Exploring the drivers of port efficiency in Latin America and the Caribbean. Transport Policy. 45, 31-45.

Serrano, B.M., Gonzalez-Cancelas, N., Soler-Flores, F., Camarero-Orive, A. 2018. Classification and prediction of port variables using Bayesian Networks. Transport Policy. 67, 57-66.

Sharif, O., Huynh, N. 2012. Yard crane scheduling at container terminals: A comparative study of centralized and decentralized approaches. Economics and Logistics. 14(2), 139-162.

Shan, J., Yu, M., Lee, C. 2014. An empirical investigation of the seaport's economic impact: Evidence from major ports in China. Transport Research Part E. 69, 41-53.

Shang, K., Lu, C. 2009. Effects of Safety Climate on Perceptions of Safety Performance in Container Terminal Operations. Transport Reviews. 29(1), 1-19.

Sheng, D., Li, Z., Fu, X., Gillen, D. 2017. Modeling the effects of unilateral and uniform emission regulations under shipping company and port competition. Transportation Research Part E.101, 99-114.

Shintani, K., Konings, R., Imai, A. 2010.The impact of foldable containers on container fleet management costs in hinterland transport. Transportation Research Part E. 46(5), 750-763.

Shi, W., Li, K.X. 2017. Themes and tools of maritime transport research during 2000-2014. Maritime Policy \& Management. 44(2), 151-169.

Shiau, T., Chuang, C. 2015.Social construction of port sustainability indicators: a case study of Keelung Port. Maritime Policy \& Management. 42(7), 712-728.

Shibasaki, R., Iijima, T., Kawakami, T., Kadono, T., Shishido, T. 2017. Network assignment model of integrating maritime and hinterland container shipping: application to Central America. Maritime Economics and Logistics. 19(2), 234-273.

Shibasaki, R., Usami, T., Furuichi, M., Teranishi, H., Kato, H. 2018. How do the new shipping routes affect Asian liquefied natural gas markets and economy? Case of the Northern Sea Route and Panama Canal expansion. Maritime Policy \& Management. 45(4), 543-566.

Shinohara, M., 2010. Maritime cluster of Japan: implications for the cluster formation policies. Maritime Policy \& Management. 37(4), 377-399.

Siemonsma, H., Nus, W.V., Uyttendaele, P. 2012. Awarding of Port PPP contracts: the added value of a competitive dialogue procedure. Maritime Policy \& Management. 39(1), 63-78.

Silva, F.G.F., Rocha, C.H. 2012. A demand impact study of southern and southeastern ports in Brazil: An indication of port competition. Economics and Logistics. 14(2), 204-219.

Simkins, Z.S., Stewart, R.D.2015. Factoring a real value of cargo in port investment and funding decisions. Maritime Policy \& Management. 42(7), 712-728.

Simões, P., Marques, R.C. 2010. Influence of Congestion Efficiency on the European Seaports Performance: Does It Matter? Transport Reviews. 30(4), 517-539.

Smid, M., Dekker, S., Wiegmans, B. 2016. Modeling the cost sensitivity of intermodal inland waterway terminals: A scenario based approach. Transportation Research Part A. 85, 112-122. 
Sohn, J., Jung, C. 2009. The size effect of a port on the container handling efficiency level and market share in international transshipment flow. Maritime Policy \& Management. 36(2), 117129.

Song, B., Cui, Y. 2014. Productivity changes in Chinese Container Terminals 20062011.Transport Policy. 35,377-384.

Song, D., Carter, J. 2009. Empty container repositioning in liner shipping. Maritime Policy \& Management. 36(4), 291-307.

Song, D., Dong, J. 2011. Effectiveness of an empty container repositioning policy with flexible destination ports. Transport Policy. 18(1), 92-101.

Song, D., Dong, J. 2011. Flow balancing-based empty container repositioning in typical shipping service routes. Maritime Economics and Logistics. 13(1), 61-77.

Song, D., Lyons, A., Li, D., Sharif, H. 2016. Modeling port competition from a transport chain perspective. Transportation Research Part E 87, 75-96.

Song, L., Geenhuizen, M. 2014. Port infrastructure investment and regional economic growth in China: Panel evidence in port regions and provinces. Transport Policy. 36, 173-183.

Song, L., Mi, J. 2016. Port infrastructure and regional economic growth in China: a Granger causality analysis. Maritime Policy \& Management. 43(4), 456-468.

Song, L., Yang, D., Chin, A.T.H., Zhang, G., He, Z., Guan, W., Mao, B .2016.A game-theoretical approach for modeling competitions in a maritime supply chain. Maritime Policy \& Management. 43(8), 976-991.

Soriani, S., Bertazzon, S., Cesare, F., Rech, G. 2009. Cruising in the Mediterranean: structural aspects and evolutionary trends. Maritime Policy \& Management. 36(3), 235- 251.

Stavroulakis, P.J., Papadimitriou, S. 2017. Situation analysis forecasting: the case of European maritime clusters. Maritime Policy \& Management. 44(6), 779-789.

Steven, A. B., Corsi, T. M. 2012. Choosing a port: An analysis of containerized imports into the US. Transport Research Part E. 48(4), 881-895.

Stevens, L.C.E., Vis, I.F.A. 2016. Port supply chain integration: analyzing biofuel supply chains. Maritime Policy \& Management. 43(3), 261-279.

Styhre, L., Winnes, H., Black, J., Lee, J., Le-Griffin, H. 2017. Greenhouse gas emissions from ships in ports - Case studies in four continents. Transportation Research Part D. 54,212-224.

Suárez-Alemán, A., Hernández, A. 2014. Incentives to reduce port inefficiency: a theoretical approach. Maritime Policy \& Management. 41(5), 462-479.

Suárez-Alemán, A., Sarriera, J.M., Serebrisky, T., Trujillo, L. 2016. When it comes to container port efficiency, are all developing regions equal? Transportation Research Part A. 86, 54-77.

Sua'rez-Alema'n, A., Serebrisky, T., Leo'n, O. P. 2017. Port reforms in Latin America and the Caribbean: where we stand, how we got here, and what is left. Maritime Economics and Logistics 1-19.

Suárez-Alemán, A., Trujillo,L., Cullinane,K.P.B. 2014.Time at ports in short sea shipping: When timing is crucial. Maritime Economics and Logistics 16(4), 399-417.

Sun, J., Yuan, Y., Yang, R., Ji, X., Wu, J. 2017. Performance evaluation of Chinese port enterprises under significant environmental concerns: An extended DEA-based analysis. Transport Policy. $60,75-86$.

Sun, Z., Zheng, J. 2016. Finding potential hub locations for liner shipping. Transportation Research Part B.93, 750-761

Talley, W.K. 2013. Maritime transportation research: topics and methodologies. Maritime Policy \& Management. 40(7), 709-725. 
Talley, W.K., Ng, M. 2016. Port economic cost functions: A service perspective. Transportation Research Part E. 88, 1-10.

Talley, W.K., Ng, M. 2016. Port multi-service congestion. Transportation Research Part E. 94, 6670.

Talley, W.K., Ng, M., Marsillac, E. 2014. Port service chains and port performance evaluation. Transport Research Part E. 69, 236-247.

Tan, Z., Li, W., Zhang, X., Yang, H. 2015.Service charge and capacity selection of an inland river port with location-dependent shipping cost and service congestion. Transportation Research Part E. 76, 13-33.

Tan, Z., Meng, Q., Wang, F., Kuang, H. 2018. Strategic integration of the inland port and shipping service for the ocean carrier. Transportation Research Part E. 110, 90-109.

Taneja, P., Walker, W.E., Ligteringen, H., Schuylenburg, M. V., Plas, R.V.D 2010. Implications of an uncertain future for port planning. Maritime Policy \& Management. 37(3), 221-245.

Tang, J., McNabola, A., Misstear, B., Caulfield, B. 2017. An evaluation of the impact of the Dublin Port Tunnel and HGV management strategy on air pollution emissions. Transportation Research Part D. 52, 1-14.

Tao, Y., Lee, C. 2015.Joint planning of berth and yard allocation in transshipment terminals using multi-cluster stacking strategy. Transportation Research Part E.83, 34-50.

Tapia, R.J., Senna, L.A.S., Larranaga, A.M., Cybis, H.B.B. 2018. Joint mode and port choice for soy production in Buenos Aires province, Argentina. In Press, Corrected Proof.

Tavasszy, L.A., Ruijgrok, K. 2012. Models: State-of-the-Art and Research Opportunities: Stateof-the-Art and Research Opportunity. Transport Reviews. 32(2), 203-219.

Tavasszy, L.A., Ruijgrok, K., Davydenko, I. 2012. Incorporating Logistics in Freight Transport Demand Models: State-of-the-Art and Research Opportunities. Transport Reviews. 32(2), 203219.

Teye, C., Bell, M.G.H., Bliemer, M. C. J. 2017. Locating urban and regional container terminals in a competitive environment: An entropy maximising approach. Transportation Research Part B. In Press, corrected proof.

Teye, C., Bell, M.G.H., Bliemer, M.C.J. 2017. Entropy maximising facility location model for port city intermodal terminals. Transportation Research Part E. 100, 1-16.

Thai, V.V., 2009. Effective maritime security: conceptual model and empirical evidence. Maritime Policy \& Management. 36(2), 147-163.

Thai, V. V. 2016. The impact of port service quality on customer satisfaction: The case of Singapore. Maritme Economics and Logistics. 18(4), 458-475.

Thai, V.V., Yeo, G., Pak, J. 2016.Comparative analysis of port competency requirements in Vietnam and Korea. Maritime Policy \& Management. 43(5), 614-629.

Thill, J., Venkitasubramanian, K. 2015. Multi-layered hinterland classification of Indian ports of containerized cargoes using GIS visualization and decision tree analysis. Maritime Economics and Logistics. 17(3), 265-291.

Tian, X., Liu, L., Wang, S.2015. Evolving competition between Hong Kong and Shenzhen ports. Maritime Policy \& Management. 42(8), 729-745.

Tichavska, M., Tovar, B. 2015. Port-city exhaust emission model: An application to cruise and ferry operations in Las Palmas Port. Transportation Research Part A. 78, 347-360

Tichavska, M., Tovar, B. 2015.Environmental cost and eco-efficiency from vessel emissions in Las Palmas Port. Transportation Research Part E. 83, 126-40. 
Tichavska, M., Tovar, B. 2017. External costs from vessel emissions at port: a review of the methodological and empirical state of the art. Transport Reviews. 37(3), 383-402.

Tichavska, M., Tovar, B., Gritsenko, D., Johansson, L., Jalkanen, J.P. 2017. Air emissions from ships in port: Does regulation make a difference? Transport Policy. In Press Corrected Proof

Ting, S., Wang, J., Kao, S., Pitty, F.M. 2010. Categorized stacking models for import containers in port container terminals. Maritime Economics and Logistics. 12(2), 162-177.

Ting, S., Tzeng, G. 2016. Bi-criteria approach to containership slot allocation in liner shipping. Maritme Economics and Logistics 18(2), 141-157.

Tongzon, J.L. 2009. Port choice and freight forwarders. Transportation Research Part E. 45(1), 186-195.

Tongzon, J.L., Lee, S. 2016. Achieving an ASEAN single shipping market: shipping and logistics firms’ perspective. Maritime Policy \& Management. 43(4), 407-419.

Tongzon, J.L., Yang, D. 2016. The rise of Chinese ports and its impact on major ports in East Asia. Maritme Economics and Logistics. 18(1), 19-40.

Tovar, B., Hernández, R., Rodríguez-Déniz, H. 2015.Container port competitiveness and connectivity: The Canary Islands main ports case. Transport Policy. 38, 40-51.

Tovar, B., Rodri'Guez-De'Niz, H. 2015.Classifying Ports for Efficiency Benchmarking: A Review and a Frontier-based Clustering Approach. Transport Reviews. 35(3), 378-400.

Tovar, B., Wall, A. 2012. Economies of scale and scope in service firms with demand uncertainty: An application to a Spanish port. Economics and Logistics. 14(3), 362-385.

Tovar, B., Wall, A. 2015. Can ports increase traffic while reducing inputs? Technical efficiency of Spanish Port Authorities using a directional distance function approach. Transportation Research Part A. 71, 128-140.

Tovar, B. Wall, A. 2014. The impact of demand uncertainty on port infrastructure costs: Useful information for regulators? Transport Policy. 33,176-183.

Tran, N.K., Haasis, H., Buer, T. 2017. Container shipping route design incorporating the costs of shipping, inland/feeder transport, inventory and $\mathrm{CO} 2$ emission. Maritime Economics and Logistics. 19(4), 667-694.

Tsai, Y., Liang, C., Huang, K., Hung, K., Jheng, C., Liang, J. 2018. Self-management of greenhouse gas and air pollutant emissions in Taichung Port, Taiwan. Transportation Research Part D.63, 576-587.

Tsamboulas, D., Lekka, A., Rentziou, A. 2014. Development of Motorways of the Sea in the Adriatic region. Maritime Policy \& Management. 42(7), 317-334.

Tu, N., Adiputranto, D., Fu, X., Li, Z. 2017. Shipping network design in a growth market: The case of Indonesia. Transportation Research Part E. In Press, Corrected Proof.

Tzannatos, E. 2010. Cost assessment of ship emission reduction methods at berth: the case of the Port of Piraeus, Greece. Maritime Policy \& Management. 37(4), 427-445.

Umang, N., Bierlaire, M., Vacca, I. 2013.Exact and heuristic methods to solve the berth allocation problem in bulk ports. Transport Research Part E. 54, 14-31.

Upadhyay, A., Gu, W., Bolia,N. 2017. Optimal loading of double-stack container trains. Transportation Research Part E. 107, 1-22.

Urciuoli, L. 2016. Port security training and education in Europe — a framework and a roadmap to harmonization. Maritime Policy \& Management. 43(5), 580-596.

Ursavas, E. 2017. Crane allocation with stability considerations. Maritime Economics and Logistics. 19(2), 379-401. 
Vaggelas, G. K., Pallis, A.A. 2010. Passenger ports: services provision and their benefits. Maritime Policy \& Management. 37(1), 73-89.

Veenstra, A., Zuidwijk, R., Asperen, E. 2012. The extended gate concept for container terminals: Expanding the notion of dry ports. Economics and Logistics. 14(1), 14-32.

Vejvar, M., Lai, K., Lo, C.K.Y., Fürst, E.W.M. 2018.Strategic responses to institutional forces pressuring sustainability practice adoption: Case-based evidence from inland port operations. Transportation Research Part D. Part B.61, 274-288.

Veldman, S., Garcia-Alonso, L., Liu, M. 2016. Testing port choice models using physical and monetary data: a comparative case study for the Spanish container trades. 43(4), 495-508.

Veldman, S., Garcia-Alonso, L., Vallejo-Pinto, J.Á. 2011. Determinants of container port choice in Spain. Maritime Policy \& Management. 38(5), 509-522.

Venturini, G., Iris, Ç., Kontovas, C.A., Larsen, A. 2017. The multi-port berth allocation problem with speed optimization and emission considerations. Transportation Research Part D. 54,142159.

Vergano, L., Umgiesser, G., Nunes, P.A.L.D. 2010. An economic assessment of the impacts of the MOSE barriers on Venice port activities. Transportation Research Part D. 15(6), 343-349

Verhoeven, P. 2009. European ports policy: meeting contemporary governance challenges. Maritime Policy \& Management. 36(1), 79-101.

Verhoeven, P. 2010. A review of port authority functions: towards a renaissance? Maritime Policy \& Management. 37(3), 247-270.

Verhetsel, A., Sel, S. 2009. World maritime cities: From which cities do container shipping companies make decisions?. Transport Policy. 16(5), 240-250.

Verhoeven, P., Vanoutrive, T. 2012. A quantitative analysis of European port governance. Maritime Economics and Logistics. 14(2), 178-203.

Vermeiren, T., Macharis, C. 2016.Intermodal land transportation systems and port choice, an analysis of stated choices among shippers in the Rhine-Scheldt delta. Maritime Policy \& Management. 43(8), 992-1004.

Vieira, G. B.B., Neto, F.J.K., Amaral, F.G.A. 2014.Governance, Governance Models and Port Performance: A Systematic Review. Transport Reviews. 34(5), 645-662.

Vojdani, N., Lootz, F., Rösner, R. 2013. Optimizing empty container logistics based on a collaborative network approach. Maritime Economics and Logistics. 15(4), 467-493.

Wan, C., Yang, Z., Zhang, D., Yan, X., Fan, S. 2018. Resilience in transportation systems: a systematic review and future directions. Transport Reviews. 38(4), 479-498.

Wan, Y., Basso, L.J., Zhang, A. 2016.Strategic investments in accessibility under port competition and inter-regional coordination. Transportation Research Part B.93, 102-125.

Wan, Y., Zhang, A., Li, K .X. 2018. Port competition with accessibility and congestion: a theoretical framework and literature review on empirical studies. Maritime Policy \& Management. 45(2), 239-259.

Wan, Y., Zhang, A., Yuen, A. C.L.2013. Urban road congestion, capacity expansion and port competition: empirical analysis of US container ports. Maritime Policy \& Management. 40(5), 417-438.

Wang, C., Chen, Q., Huang, R. 2018. Locating dry ports on a network: a case study on Tianjin Port. Maritime Policy \& Management. 45(1), 71-88.

Wang, G.W., Knox, K.J., Lee, P .T. 2013. A study of relative efficiency between privatised and publicly operated US ports. Maritime Policy \& Management. 40(4), 351-366. 
Wang, G.W.Y., Pallis, A.A. 2014. Incentive approaches to overcome moral hazard in port concession agreements. Transport Research Part E. 67,162-174.

Wang, G.W.Y., Zeng, Q., Li, K., Yang, J. 2016. Port connectivity in a logistic network: The case of Bohai Bay, China. Transportation Research Part E. 95, 341-354.

Wang, H., Nozick, L., Xu, N., Gearhart, J. 2018. Modeling ocean, rail, and truck transportation flows to support policy analysis. Maritime Economics and Logistics, 20(3), 327-357.

Wang, H., Wang, S., Meng, Q. 2014.Simultaneous optimization of schedule coordination and cargo allocation for liner container shipping networks. Transport Research Part E.70, 261-273

Wang, J.J., Cheng, M.C.B.2015. Mature hub ports in the free trade environment, the way forward from a global supply chain perspective: an Asian case. Maritime Policy \& Management. 42(5), 436-458.

Wang, K., Liu, W., Wang, S., Liu, Z. 2017. Optimal reefer slot conversion for container freight transportation. Maritime Policy \& Management. 44(6), 727-743.

Wang, K., Ng, A.K. Y., Lam, J.S.L., Fu, X.2012.Cooperation or competition? Factors and conditions affecting regional port governance in South China. Economics and Logistics. 14(3), 386-408.

Wang, K., Wang, S., Zhen, L., Qu, X. 2017. Cruise service planning considering berth availability and decreasing marginal profit. Transportation Research Part B.104, 543-567.

Wang, L., Goodchild, A., Wang, Y. 2017. The effect of distance on cargo flows: a case study of Chinese imports and their hinterland destinations. Maritime Economics and Logistics. 20(3), 456-475.

Wang, L., Zhu, Y., Ducruet, C., Bunel, M., Lau, Y. 2018. From hierarchy to networking: the evolution of the "twenty-first-century Maritime Silk Road" container shipping system. Transport Reviews. 38(4), 416-435.

Wang, P., Mileski, J.P., Zeng, Q. 2017. Alignments between strategic content and process structure: the case of container terminal service process automation. Maritime Economics and Logistics. 1-16.

Wang, S., Liu, Z., Qu, X. 2017. Weekly container delivery patterns in liner shipping planning models. Maritime Policy \& Management. 44(4), 442-457.

Wang, S., Meng, Q. 2012. Liner ship route schedule design with sea contingency time and port time uncertainty. Transport Research Part B. 46(5), 615- 633.

Wang, S., Meng, Q. 2013. Reversing port rotation directions in a container liner shipping network. Transport Research Part B. 50, 61-73.

Wang, S., Qu, X., Yang, Y. 2015. Estimation of the perceived value of transit time for containerized cargoes. Transportation Research Part A. 78, 298-308.

Wang, S., Yang, D., Lu, J. 2018. A connectivity reliability-cost approach for path selection in the maritime transportation of China's crude oil imports. Maritime Policy \& Management. 45(5), 567-584.

Wang, S., Zhen, L., Zhuge, D. 2018. Dynamic programming algorithms for selection of waste disposal ports in cruise shipping. Transportation Research Part B.108, 235-248.

Wang, X., Meng, Q. 2011.The impact of land bridge on the market shares of Asian ports. Transport Research Part E. 47(2), 190-203.

Wang, X., Meng, Q., Miao, L. 2016. Delimiting port hinterlands based on intermodal network flows: Model and algorithm. Transportation Research Part E 88, 32-51. 
Wang, Y., Cullinane, K. 2014. Traffic consolidation in East Asian container ports: A network flow analysis. Transport Research Part A. 61, 152-163.

Wang, Y., Cullinane, K. 2016. Determinants of port centrality in maritime container transportation. Transportation Research Part E. 95, 326-340.

Wang, Y., Yeo, G. 2018. Intermodal route selection for cargo transportation from Korea to Central Asia by adopting Fuzzy Delphi and Fuzzy ELECTRE I methods. Maritime Policy \& Management 45(1), 3-18.

Wang, Y., Yeo, G., Ng, A. K. Y. 2014.Choosing optimal bunkering ports for liner shipping companies: A hybrid Fuzzy-Delphi-TOPSIS approach. Transport Policy.35, 358-368.

Wanke, P., Nwaogbe, O.R., Chen, Z. 2018. Efficiency in Nigerian ports: handling imprecise data with a two-stage fuzzy approach. Maritime Policy \& Management. 45(5), 699-715.

Wanke, P.F., 2013. Physical infrastructure and shipment consolidation efficiency drivers in Brazilian ports: A two-stage network-DEA approach. Transport Policy. 29, 145-153.

Wanke, P.F., Barbastefano, R.G., Hijjar, M.F.2011. Determinants of Efficiency at Major Brazilian Port Terminals. Transport Reviews. 31(5), 653-677.

Wei, H., Sheng, Z., Lee, P.T. 2018. The role of dry port in hub-and-spoke network under Belt and Road Initiative. Maritime Policy \& Management. 45(3), 370-387.

Wei, H., Sheng, Z. 2018. Logistics connectivity considering import and export for Chinese inland regions in the 21 stCentury Maritime Silk Road by dry ports. Maritime Policy \& Management. 45(1), 53-70.

Wen, C., Hsu, P., Cheng, M. 2017. Applying intelligent methods in detecting maritime smuggling. Maritime Economics and Logistics. 19(3), 573-599.

Wiegmans, B.W., Konings, R., Priemus, H. 2009. Critical mass for the development of a new container port in Vlissingen. Maritime Economics and Logistics. 11(4), 399-417.

Wiegmans, B., Menger, I., Behdani, B., Arem, B. 2017. Communication between deep sea container terminals and hinterland stakeholders: information needs and the relevance of information exchange. Maritime Economics and Logistics. 1-18.

Wiegmans, B., Witte, P. 2017. Efficiency of inland waterway container terminals: Stochastic frontier and data envelopment analysis to analyze the capacity design- and throughput efficiency. Transportation Research Part A.106, 12-21.

Wiegmans, B., Witte, P., Spit, T. 2015.Characteristics of European inland ports: A statistical analysis of inland waterway port development in Dutch municipalities. Transportation Research Part A. 78, 566-577.

Wilmsmeier, G., Cullinane, K.P.B., Notteboom, T., Sanchez, J.R. 2012.IAME 2011 contemporary studies on maritime. Maritime Policy \& Management. 39(6), 549-554.

Wilmsmeier, G., Monios, J. 2013. Counterbalancing peripherality and concentration: an analysis of the UK container port system. Policy \& Management. 40(2), 116-132.

Wong, E.Y.C., Tai, A. H., Raman, M. 2015. A maritime container repositioning yield-based optimization model with uncertain upsurge demand. Transportation Research Part E.82, 147161.

Woo, J., Moon, D.S.H., Lam, J. S.L. 2018. The impact of environmental policy on ports and the associated economic opportunities. Transportation Research Part A.110, 234-242

Woo, S., Bang, H., Martin, S., Li, K. X. 2013. Evolution of research themes in Maritime Policy \& Management-1973-2012. Maritime Policy \& Management. 40(3), 200-225.

Woo, S., Kang, D., Martin, S. 2013.Seaport Research: An Analysis of Research Collaboration using Social Network Analysis. Transport Reviews. 33(4), 460-475. 
Woo, S., Kim, S., Kwak, D., Pettit, S., Beresford, A. 2018. Multimodal route choice in maritime transportation: the case of Korean auto-parts exporters. Maritime Policy \& Management. 45(1), 19-33.

Woo, S., Pettit, S. J. 2011.Seaport research: A structured literature review on methodological issues since the 1980s. Transport Research Part A. 45(7), 667-685.

Woo, S., Pettit, S., Beresford, A.K.C. 2011. Port evolution and performance in changing logistics environments. Maritime Economics and Logistics. 13(3), 250-277.

Woo, S., Pettit, S., Beresford, A.K.C., Kwak, D. 2012.Seaport Research: A Decadal Analysis of Trends and Themes since the 1980s. Transport Reviews. 32(3), 351-377.

Woodburn, A. 2017. An analysis of rail freight operational efficiency and mode share in the British port-hinterland container market. Transportation Research Part D. 51,190-202.

Wu, Y. J., Goh, M. 2010. Container port efficiency in emerging and more advanced markets. Transportation Research Part E. 46(6), 1030-1042.

Wu, J., Yan, H., Liu, J. 2010. DEA models for identifying sensitive performance measures in container port evaluation. Maritime Economics and Logistics. 12(3), 215-236.

Wu, J., Yan, H., Liu, J. 2010. Groups in DEA based cross-evaluation: An application to Asian container ports. Maritime Policy \& Management. 37(6), 545-558.

Wu, S., Li, K.X., Shi, W., Yang, Z. 2016. Influence of local government on port investment: implications of China's decentralized port governance system. Maritime Policy \& Management. 43(7), 777-797.

Xiao, Y., Fu, X., Ng, A.K.Y., Zhang, A. 2015. Port investments on coastal and marine disasters prevention: Economic modeling and implications. Transportation Research Part B. 78, 202221.

Xiao, Y., Ng, A.K.Y., Yang, H., Fu, X. 2012. An analysis of the dynamics of ownership, capacity investments and pricing structure of ports. Transport Reviews. 32(5), 629-652.

Xiao, Y., Wang, S., Liu, J.J., Xiao, J., Hu, Y. 2016.Throughput estimation based port development and management policies analysis. Maritime Policy \& Management. 43(1), 1-14.

Xie, G., Qian, Y., Yang, H. 2018. Forecasting container throughput based on wavelet transforms within a decomposition ensemble methodology: a case study of China Maritime Policy \& Management. In Press, Corrected Proof.

Xie, G., Zhang, N., Wang, S. 2017. Data characteristic analysis and model selection for container throughput forecasting within a decomposition-ensemble methodology. Transportation Research Part E. 108,160-178.

Xing, W., Liu, Q., Chen, G. 2018. Pricing strategies for port competition and cooperation. Maritime Policy \& Management. 45(2), 260-277.

Xing, J., Zhong, M. 2017. A reactive container rerouting model for container flow recovery in a hub-and-spoke liner shipping network. Maritime Policy \& Management. 44(6), 744-760.

Xue, Z., Zhang, C., Lin, W., Miao, L., Yang, P. 2014.A tabu search heuristic for the local container drayage problem under a new operation mode. Transport Research Part E.62, 136-150.

Yahalom, S., Guan, C. 2018. Containership port time: The bay time factor. Maritime Economics and Logistics, 20(2), 211-227.

Yan, X., Nie, X. 2016. Optimal placement of multiple types of detectors under a small vessel attack threat to port security. Transportation Research Part E 93, 71-94.

Yan, J., Sun, X., Liu, J.J.2009. Assessing container operator efficiency with heterogeneous and time-varying production frontiers. Transportation Research Part B. 43(1), 172-185. 
Yang, C., Tai, H., Chiu, W. 2014. Factors influencing container carriers' use of coastal shipping. Maritime Policy \& Management. 41(2), 192-208.

Yang, D., Chin, A.T.H., Chen, S. 2014. Impact of politics, economic events and port policies on the evolution of maritime traffic in Chinese ports. Maritime Policy \& Management. 41(4), 346366.

Yang, D., Pan, K., Wang, S. 2017. On service network improvement for shipping lines under the one belt one road initiative of China. Transportation Research Part E. In Press Corrected Proof.

Yang, D., Wang, S. 2017. Analysis of the development potential of bulk shipping network on the Yangtze River. Maritime Policy \& Management. 44(4), 512-523.

Yang, W., Liang, G., Ding, J. 2013. Identifying solutions for adding service value to international port logistics centers in Taiwan. Maritime Economics and Logistics. 15(4), 395-415.

Yang, Y., Chen, S. 2016. Determinants of global logistics hub ports: Comparison of the port development policies of Taiwan, Korea, and Japan. Transport Policy. 45, 179-189.

Yang, Y., Lin, C. 2013. Performance analysis of cargo-handling equipment from a green container terminal perspective. Transport Research Part D. 23, 9-11.

Yang, Z., Chen, K., Notteboom, T. 2012. Optimal design of container liner services: Interactions with the transport demand in ports. Economics and Logistics. 14(4), 409-434.

Yang, Z., Ng, A.K.Y., Lee, P. T., Wang, T., Qu, Z., Rodrigues, V. S., Pettit, S., Harris, I., Zhang, D., Lau, Y. 2018.Risk and cost evaluation of port adaptation measures to climate change impacts. Transportation Research Part D. Part B.63, 444-458.

Yang, Z., Ng, A.K.Y., Wang, J. 2014. A new risk quantification approach in port facility security assessment. Transport Research Part A. 59, 72-90.

Yang, Z., Shi, H., Chen, K., Bao, H. 2014.Optimization of container liner network on the Yangtze River. Maritime Policy \& Management. 41(1), 79-96.

Yang, Z., Xiu, Q., Chen, D. 2010. Historical changes in the port and shipping industry in Hong Kong and the underlying policies. Transport Policy. In Press, Corrected Proof.

Yang, Z., Yang, Z., Yin, J. 2018.Realising advanced risk-based port state control inspection using data-driven Bayesian networks. Transportation Research Part A.110, 38-56.

Yap, W.Y., Notteboom, T. 2011. Dynamics of liner shipping service scheduling and their impact on container port competition. Maritime Policy \& Management. 38(5), 471-485.

Yeo, G., Ng, A.K.Y., Lee, P.T., Yang, Z. 2013. Modelling port choice in an uncertain environment. Maritime Policy \& Management. 40(3), 251-267.

Yeo, G., Pak, J., Yang, Z. 2013. Analysis of dynamic effects on seaports adopting port security policy. Transport Research Part A. 49, 285-301.

Yiğit, K., Kökkülünk, G., Parlak, A., Karakaş, A. 2016. Energy cost assessment of shoreside power supply considering the smart grid concept: a case study for a bulk carrier ship. Maritime Policy \& Management. 43(4), 469-482.

Yip, T. L., Liu, J.J., Fu, X., Feng, J.2014. Modeling the effects of competition on seaport terminal awarding. Transport Policy.35, 341-349.

Yoon, J., Lee, H.Y., Dinwoodie, J. 2015.Competitiveness of container terminal operating companies in South Korea and the industry-university-government network. Transportation Research Part A. 80, 1-14.

Yu, M., Fransoo, J.C., Lee, C. 2018. Detention decisions for empty containers in the hinterland transportation system. Transportation Research Part B.110, 188-208. 
Yu, H., Ge, Y., Chen, J., Luo, L., Liu, D., Tan, C. 2017. Incorporating container location dispersion into evaluating GCR performance at a transhipment terminal. Maritime Policy \& Management. 45(6), 770-786.

Yu, H., Ge, Y., Chen, J., Luo, L., Tan, C., Liu, D. 2017. CO2 emission evaluation of yard tractors during loading at container terminals. Transportation Research Part D. 51, 240-249

Yudhistira, M.H., Sofiyandi, Y. 2017. Seaport status, port access, and regional economic development in Indonesia. Maritime Economics and Logistics. 1-20.

Yuen, A.C., Zhang, A., Cheung, W .2013.Foreign participation and competition: A way to improve the container port efficiency in China? Transport Research Part A. 49, 220-231.

Yuen, K.F., Thai, V. 2017. Barriers to supply chain integration in the maritime logistics industry. Maritime Economics and Logistics. 19(3), 551-572.

Zahran, S.Z., Alam,J.B., Al- Zahrani, A.H., Smirlis,Y., Papadimitriou,S., Tsioumas,V. 2017. Analysis of port authority efficiency using data envelopment analysis. Maritime Economics and Logistics. 19(3), 518-537.

Zamboni, G., André, M., Roveda, A., Capobianco, M. 2015. Experimental evaluation of Heavy Duty Vehicle speed patterns in urban and port areas and estimation of their fuel consumption and exhaust emissions. Transportation Research Part D. 35, 1-10.

Zeng, Q., Feng, Y., Chen, Z. 2017. Optimizing berth allocation and storage space in direct transshipment operations at container terminals. Maritime Economics and Logistics. 19(3), 474-503.

Zeng, Q., Wang, G.W.Y., Qu, C., Li,K.X. 2017.Impact of the Carat Canal on the evolution of hub ports under China's Belt and Road initiative. Transportation Research Part E. In Press, Corrected Proof.

Zhang, A., Lam, J.S.L. 2013. Maritime cluster evolution based on symbiosis theory and LotkaVolterra model. Maritime Policy \& Management. 40(2). 161-176.

Zhang, A., Lam, J.S.L., Huang, G.Q. 2014. Port strategy in the era of supply chain management: the case of Hong Kong. Maritime Policy \& Management. 41(4), 367-383.

Zhang, D., Zhan, Q., Chen, Y., Li, S .2018. Joint optimization of logistics infrastructure investments and subsidies in a regional logistics network with $\mathrm{CO} 2$ emission reduction targets. Transportation Research Part D.60, 174-190.

Zhang, J. 2016. Quasi-landlord port financing in China: Features, practice and a contract theory analysis. Transportation Research Part A. 89, 73-88.

Zhang, Q., Geerlings, H., Makhloufi, A. E., Chen, S. 2018. Who governs and what is governed in port governance: A review study. Transport Policy. 64, 51-60.

Zhang, Q., Wang, W., Peng, Y., Zhang, J., Guo, Z. 2018. A game-theoretical model of port competition on intermodal network and pricing strategy. Transportation Research Part E.114, 19-39.

Zhang, R., Lu, J., Wang, D. 2014. Container drayage problem with flexible orders and its near real-time solution strategies. Transport Research Part E.61, 235-251.

Zhang, R., Zhu, L. 2018.Threshold incorporating freight choice modeling for hinterland leg transportation chain of export containers. Transportation Research Part A. In Press Corrected Proof.

Zhang, S., Ruan, X., Xia, Y., Feng, X. 2018. Foldable container in empty container repositioning in intermodal transportation network of Belt and Road Initiative: strengths and limitations. Maritime Policy \& Management. 45(3), 351-369. 
Zhang, W., Lam, J.S.L. 2017. An empirical analysis of maritime cluster evolution from the port development perspective - Cases of London and Hong Kong. Transportation Research Part A.105, 219-232.

Zhang, X., Zeng, Q., Yang, Z. 2016. Modeling the mixed storage strategy for quay crane double cycling in container terminals. Transportation Research Part E.94, 171-187.

Zhang, X., Zeng, Q., Yang, Z. 2018. Optimization of truck appointments in container terminals. Maritime Economics and Logistics, 1-21.

Zhang, Y., Lam, J.S.L. 2016. Estimating economic losses of industry clusters due to port disruptions. Transportation Research Part A. 91, 17-33.

Zhang, Z., Figliozzi, M.A. 2010. A Survey of China's Logistics Industry and the Impacts of Transport Delays on Importers and Exporters. Transport Reviews. 30(2), 179-194.

Zhang, L., Meng, Q., Fwa, T.F. 2017. Big AIS data based spatial-temporal analyses of ship traffic in Singapore port waters. Transportation Research Part E. Available online 10 August 2017.

Zhao, Q.H., Chen, S., Leung, S.C.H., Lai, K.K. 2010. Integration of inventory and transportation decisions in a logistics system. Transportation Research Part E. 46(6), 913-925.

Zhao, W., Goodchild, A.V. 2010. The impact of truck arrival information on container terminal rehandling. Transportation Research Part E. 46(3), 327-343.

Zhao, W., Goodchild, A.V.2013. Using the truck appointment system to improve yard efficiency in container terminals. Maritime Economics and Logistics. 15(1), 101-119.

Zhao, W., Goodchild, A.V. 2011.Truck travel time reliability and prediction in a port drayage network. Maritime Economics and Logistics. 13(4), 387-418.

Zhao, X., Yan, H., Zhang, J. 2017. A critical review of container security operations. Maritime Policy \& Management. 44(2), 170-186.

Zhen, L. 2014. Container yard template planning under uncertain maritime market. Transport Research Part E.69, 199-217.

Zhen, L., 2016. Modeling of yard congestion and optimization of yard template in container ports. Transportation Research Part B.90, 83-104.

Zhen, L., Liang, Z., Zhuge, D., Lee, L.H., Chew, E. P. 2017. Daily berth planning in a tidal port with channel flow control. Transportation Research Part B.106, 193-217.

Zhen, L., Xu, Z., Wang, K., Ding, Y. 2016. Multi-period yard template planning in container terminals. Transportation Research Part B.93, 700-719.

Zheng, J., Meng, Q., Sun, Z. 2015.Liner hub-and-spoke shipping network design. Transportation Research Part E. 75, 32-48.

Zheng, J., Qi, J., Sun, Z., Li, F. 2018. Community structure based global hub location problem in liner shipping. Transportation Research Part E. 118, 1-19.

Zheng, S., Ge, Y., Fu, X., Nie, Y., Xie, C. 2017. Modeling collusion-proof port emission regulation of cargo-handling activities under incomplete information. Transportation Research Part B.104, 543-567.

Zheng, S., Negenborn, R.R. 2014.Centralization or decentralization: A comparative analysis of port regulation modes. Transport Research Part E. 69, 21-40.

Zheng, S., Negenborn, R .R. 2017.Terminal investment timing decisions in a competitive setting with uncertainty using a real option approach. Maritime Policy \& Management. 44(3), 392-411.

Zheng, S., Negenborn, R.R. 2018. Design of port regulation mechanisms for multilayer governance: A shanghai case study. Maritime Economics and Logistics. 20(1), 89-111.

Zheng, S., Yin, C. 2015. Technical, allocative and cost efficiencies of Chinese ports. Maritime Policy \& Management. 42(8), 746-758. 
Zhuang, W., Luo. M., Fu, X. 2014. A game theory analysis of port specialization-implications to the Chinese port industry. Maritime Policy \& Management. 41(3), 268-287.

Zis, T., North,R. J., Angeloudis,P., Ochieng, W. Y., Bell,M.G.H.2014. Evaluation of cold ironing and speed reduction policies to reduce ship emissions near and at ports. Maritime Economics and Logistics. 16(4), 371-398.

Zondag, B., Bucci, P., Gützkow, P., Jong, G .2010. Port competition modeling including maritime, port, and hinterland characteristics. Maritime Policy \& Management. 37(3), 179-194. 